\title{
An evolutionary perspective on the emergence and implementation of mission-oriented innovation policy: the example of the change of the leitmotif from biotechnology to bioeconomy
}

\author{
Leonard Prochaska ${ }^{1} \cdot$ Daniel Schiller $^{1}$
}

Received: 16 March 2020 / Accepted: 1 January 2021/ Published online: 1 April 2021

(C) The Author(s) 2021

\begin{abstract}
The design and implementation of innovation policy funding programmes has been the subject of scientific and political debate for decades. Especially the increasingly popular approach of mission-oriented innovation policies is a much discussed subject. The question of how missions arise, what rhetoric accompanies them and how they are eventually implemented has not yet been sufficiently clarified and specification is lacking. Whether mission-oriented innovation policy actually follows a strict topdown logic, or whether the policymaking process rather resembles a certain evolutionary scheme is questioned in this study. On the basis of the change within many policy strategy papers from biotechnology to a much broader bioeconomy, it is shown that, in reality, the transition does not follow a linear sequence. Neither excessive prioritisation nor neglect of a selected sector can be confirmed in this analysis. Within the bioeconomy, however, a clear change can be identified. Biotechnology funding was visibly reduced as part of the change of leitmotif while R\&D increased in the agricultural sector in particular. Furthermore, it becomes clear that the issue of missing markets, which is predicted in theoretical studies, can also be confirmed empirically. So far, in terms of public involvement, little effort has been invested in the practical application of bioeconomical knowledge, which is why the intended transition towards bio-based economic activities is lagging behind expectations.
\end{abstract}

Keywords Innovation policy $\cdot$ Policy design $\cdot$ Funding data $\cdot$ Biotechnology $\cdot$ Bioeconomy JEL codes $\mathrm{H} 50 \cdot \mathrm{O} 38 \cdot \mathrm{O} 52 \cdot \mathrm{Q} 57$

Leonard Prochaska

leonard.prochaska@uni-greifswald.de

Extended author information available on the last page of the article 


\section{Introduction}

The notion of transformative system change and its implementation has been the subject of discussion in various disciplines for some time now. In the context of innovation policy, Weber and Rohracher (2012) illustrated the rationales for governmental interventions in order to initiate sustainable development and turn away from pure growth-thinking. In the past, classical mission-oriented strategies that go beyond a market-fixing mechanism and instead pursue market-shaping strategies have earned their justification. The idea of 'tilting the playing field' in the direction of markets or technologies identified by the government, generated the opportunity and necessity to anticipate and trigger desired technological paths, although they often focused narrowly on technical innovations (e.g. Apollo Project or Cleantech-industries) (Aghion et al. 2009; Mazzucato and Perez 2015, p. 245). Yet, the aim of modern innovation policies has progressed over time and adjusted to new conditions and challenges. Thus, increasingly more holistic, fundamental and normative elements of the socio-technical system are being targeted (Daimer et al. 2012). In fact, Kattel and Mazzucato (2018) portray the evolutionary development of innovation policy and categorise it into three stages. Accordingly, the most recent innovation policy era is characterised by normative principles and distinguishes itself from previous generations by its comprehensive approach that also includes non-technical innovations (Kuhlmann and Rip 2018). A prominent example of such a modern approach, that tackles far-reaching and fundamental shortcomings, is the Grand Societal Challenges (GSC), which are addressed, for instance, in the EU's mission-oriented framework programme Horizon 2020 (Daimer et al. 2012). One integral objective within the EU's GSCs as well as in various other sovereign countries is the implementation of a bioeconomy (GBC 2018; EU 2020). Over the last couple of years, the concept of a bioeconomy (the term 'bio-based economy' is used synonymously in this paper) has gained momentum due to the urgency to overcome dependence on fossil resources and also as a response to anthropogenic climate change. In simple terms, bioeconomy is understood as the concept of a 'gradual replacement of fossil-based feedstocks with bio-based ones’ (OECD 2018, p. 11). A wide range of published strategy papers and interest groups, such as environmentalists or dedicated companies, have raised awareness of a bio-based economy as a leitmotif for politics, economy, the public and science.

It shows that innovation policy and the character of targeted objectives have evolved successively. However, it is often not clear how a transition of policy goals is defined and consequently pursued. In light of this fact, it is our aim to assess whether and in what way the shift in political discourse from biotechnology to bioeconomy has been reflected by a transition in both funding programmes and projects. In order to achieve this, we go back to the origin of public bio-themed R\&D support at a programmatic level, starting with systemic biotechnology funding, and illustrate the evolution from biotechnology to bioeconomy. At the same time, we trace the implementation at a project level so that we can both assess the actual execution of the stated transition and identify the priorities within the bioeconomy. For this purpose, we built a database consisting of all relevant bioeconomy projects that have been funded by the German government between 1995 and 2015. In the process, we divided the bioeconomy into its components to determine realised funding measures. We chose Germany as the observation unit due to its early commitment to the bioeconomy and the availability of sufficient data, which allows an examination of the funding patterns and for conclusions to be drawn about the policy change over time. 
With this study we are contributing to existing research in two respects. Firstly, by tracing the evolution of thematic shifts at both programmatic and project levels, we gain a better understanding of how political trends emerge, develop and are implemented. There is still a lack of knowledge about evolutionary mechanisms underlying policymaking processes. By addressing the different leitmotifs of biotechnology and bioeconomy support, we are able to shed light on the question whether policy evolution either follows a linear top-down approach or is rather accompanied by bottom-up dynamics and feedback loops. Secondly, social-science literature dedicated to the bioeconomy is still rare and based on different opinions about the bioeconomy's scope. We therefore make the bioeconomy tangible by dissecting it and thus illustrate its comprehensive character along several parts of the value chain from raw materials to final products and industrial applications. This allows us to categorise and quantify its publicly funded knowledge-based component.

This article is structured as follows: First we discuss the transformation of innovation policies and outline the topic of mission-oriented strategies more in greater detail. This is succeeded by a discussion of mechanisms in the policymaking process. Subsequently, we embed this discussion in the bioeconomy context, followed by an historical overview of bio-related funding in Germany on a programmatic level. Thereafter, the data at the project level are described, analysed and evaluated. Finally, the results are discussed and conclusions are drawn.

\section{Innovation policy in a state of change}

Within the last two decades increasingly more attention has been paid to the subject of innovation policy (Edler and Fagerberg 2017). As Edler et al. (2016) emphasise, there are manifold innovation policy instruments to attain certain objectives within economies, either through supply- or demand-side policy. This set of policy tools has undergone a persistent progression and can be distinguished according to the corresponding theoretical principles (Schot and Steinmueller 2018). In the second half of the twentieth century, neoclassical thinking has dominated economics. The integration of technological progress as a decisive factor for growth (cf. Solow-Swan model) led to the pursuit of a policy scheme with the primary goal to prevent market-failures such as insufficient R\&D spending. Consequently, funding for foundational research or direct support to firm $R \& D$ have been the most common and popular instruments in this era (Edler and Fagerberg 2017; Kattel and Mazzucato 2018). Further applied mechanisms were regulations and direct subsidies for specific industries like tax treatments (Schot and Steinmueller 2018). This conception altered considerably in the late 1980s due to the establishment of the innovation system approach amongst others by Freeman (1987) and Freeman and Lundvall (1988) (Weber and Rohracher 2012). By acknowledging failures at the system-level, new policy tools complemented the former market failure-perspective. As a result, cluster policies, network stimulating approaches and the encouragement of agency such as start-up finance and fostering entrepreneurship have been introduced as crucial means (Edler and Fagerberg 2017). Up to this point, economic incentives such as preventing inferior technical systems, relinquishing industries in a state of negative lock-in or gaining first-mover advantages in novel technologies were main rationales for innovation policy (Aghion et al. 2009). However, increasingly negative social and ecological externalities, partially induced by growth and innovation, required a new political discourse (Weber and Rohracher 2012; Biggi and Giuliani 2020). While Kattel and 
Mazzucato (2018, p. 788) identified a 'normative turn' in modern policy strategies, Weber and Rohracher (2012) as well as Schot and Steinmueller (2018) point to the necessity of a transformative innovation policy. Climate change, growing income disparities within and between countries, and lack of access to education are just some examples for comprehensive problems that need to be tackled by governmental authorities. This, again, requires novel practices in policy steering and illustrate the incessant adjustments that are mandatory in order to cope with changing circumstances.

One highly debated aspect in this context is the proactive mission-oriented approach to overcome conventional 'neutral' innovation policies (i. a. Martin 1995; Aghion et al. 2009; Weber and Rohracher 2012; Kivimaa and Kern 2016; Mazzucato and Semieniuk 2017). In lieu of subsidising regardless of the technological field, systematic funding that contributes to a selected mission is more likely to shake up existing structures than mere broad unspecific funding tending to maintain the status quo. Mazzucato (2014, p. 5) justifies the necessity of state intervention since it is 'providing the vision and the dynamic push to make things happen that otherwise would not have' and implies the government's opportunities to take up structural challenges and shape necessary markets. Since individual firms are not capable to solve problems that span multiple sectors and most economic actors have a lack of commercial incentives, national or even supranational policies are crucial in order to create a coherent, stable and long-term roadmap as well as to compensate for deficient investments in the private sector (Mazzucato 2014). In addition, commercial actors rarely contribute financially to basic and applied research since new developments in emerging sectors are highly uncertain and therefore risky. This lack of patient or long-term investments in more difficult to manage and ambitious paths is a restraining factor for scientific advancement. Therefore, the rationale behind public involvement is well established (Aghion et al. 2009).

Nonetheless, there is also scepticism with regard to mission-oriented policies. For instance, since it is anything but trivial for a government authority to plan and forecast the economic system (Hayek 1945) and because of imperfect knowledge (or 'pretence of knowledge' (Hayek 1975)) there is a risk involved with merely 'picking winners'. The most uncertain and demanding part of policies is to identify or rather anticipate market-failures as a basis for the development of appropriate programme designs (Ergas 1987). This is related with a distortion of competition by public authorities and could potentially carry a certain arbitrariness. To illustrate the latent underlying risk of this process, Hughes $(2012$, p. 39) terms this process as 'choosing races and placing bets'. Moreover, the concrete realisation of a comprehensive, normative mission such as the implementation of a bio-based economy remains a highly complex task. A deeper understanding is needed whether clearly articulated missions (Frenken 2017; Mazzucato 2018), room for experimentation on all levels (policy design, producer, user, society etc.) (Weber and Rohracher 2012; Schot and Steinmueller 2018), or a combination of both might suit best for holistic objectives that concern the entirety of a (global) system.

\section{The character of mission-oriented policymaking processes}

A considerable part of the criticism about mission-oriented approaches within innovation policy is provoked by its strict top-down character. In other words, the fact that political decision-makers determine a distinct direction that favours chosen technologies or economic sectors and thereby neglects or weakens other segments of the 
economy might lead to the distortion of natural competition. Along with this argument, there is also the question of how missions are chosen and how they are implemented. According to Mazzucato (2014), one main argument for the state's intervention is to supply a specific vision or strategy that can be pursued mutually and otherwise would not have been tackled. Therefore, a linear top-down process could be assumed: a goal will be set by the policy and is accompanied by a certain political and public discourse and rhetoric, which will subsequently be expressed in the form of concrete funding programmes. This, in turn, is reflected in changed foci of funded projects that contribute to the stated mission.

However, in political science, over many decades a lively discussion has evolved around the character of the policymaking process (Weible 2014). In the past, this process was often understood as a multipart process that was divided into several stages such as 'Issue Definition', 'Agenda Setting', 'Policy Adoption', 'Implementation' or 'Policy Evaluation' (deLeon 1999). Initially, Lasswell (1956) conceptualised the public policymaking as a 7step linear temporal-sequential process, which built the foundation for more elaborate phasebased concepts. Within this framework, Jones (1970) derived the notion of a policy cycle, which emphasises the evolutionary and self-evaluative nature of public policies, and only comes to an end when a policy is terminated. Subsequently, this theoretical model faced varied criticism, for instance that a classification into a specific sequence is neither a realistic assumption nor empirically verifiable (Sabatier and Jenkins-Smith 1993). Furthermore, the basic presumption of the top-down character of policies might lead to a bias that oversimplifies the interaction between stages, actors and other policy programmes (Sabatier and Jenkins-Smith 1993). For that reason, work in contemporary literature rather focusses on specific elements of the policy cycle, integrates theories into the entire policy process or is dissociated from thinking in distinct stages (Sabatier and Weible 2014).

Since there is a clear lack of empirical evidence about the issue of the emergence and development of novel missions or policy strategies, an explorative analysis can help provide a more detailed understanding of this process. Based on these theoretical deliberations about mission-oriented policy on the one hand and the policymaking process on the other, two contrary trajectories of policy formulation and implementation seem possible:

1. The mission-oriented policy is implemented in a linear, top-down manner. Thus, the policymakers provide the foresight to steer the process in the direction of a specific mission and subsequently, priorities in policy and the direction of projects change correspondingly.

2. The development of any policy, from identifying a mission to changing priorities within strategies to actual implementation, is a combination of top-down and bottom-up mechanisms, i.e., it resembles rather a self-renewing and evolutionary process with several interactions between not clearly separated stages.

This empirical study on bioeconomy in Germany, therefore, concentrates on the interplay between the political discourse and the implementation of the priorities determined in the form of enacted programmes and executed projects. That means, two factors are most essential in this context: timing and content. In case (a), the government sets the mission (biotechnology and bioeconomy) and consequently initiates corresponding funding programmes dedicated to this goal shortly after. Consequently, there are measurable rapid changes in quantity and content in publicly-funded $R \& D$ projects in the respective field. If 
(b) applies, we assume that the mission is connected to preceding missions and is in constant evolution due to successes and failures. Funding programmes are also inspired by previous experiences and are adapted to changing circumstances. In consequence, alterations in project content and numbers will rather appear more steadily over a longer time frame.

In order to probe the case, we will initially shed light on the public bioeconomy discourse, before we concentrate on the development of funding programmes for the bioeconomy. Ultimately, analysis at the operative project level will provide insights into the implementation of the bioeconomy discourse.

\section{The public bioeconomy discourse}

Within the last decade, the notion of a bioeconomy replacing the current fossil resource-based economy has become prominent due to the desire to find an instrument to combat anthropogenic climate change, to transform energy systems towards renewable energies or even to deal with world hunger.

While previous support programmes had often focussed on biotechnology, the EU introduced the approach of a knowledge-based bioeconomy (KBBE) within their 'Seventh Framework Programme' in 2004 (Golembiewski et al. 2015). Subsequently, several other countries seized the idea of holistic bio-based systems with different national flavours depending on their idea of bioeconomy (McCormick and Kautto 2013). For instance, in 2010, the government in Germany announced a funding programme along with a policy strategy targeting the transition towards an integrated bioeconomy as one of the first countries to do so. This financing scheme is part of the 'Hightech-Strategy' which has been running since 2006 and represents a mission-oriented approach to benefit from the enhancing nature of the strong NIS (BMBF 2017b). Moreover, the funding measure meets the EU's requirements to invest in education and R\&D, as stipulated in the Lisbon Strategy (2000) and Europe 2020 (2010) (EP 2000; EC 2018).

It has become clear that, amongst others, politicians have high expectations that this approach will contribute to solutions for EU's GSCs and to reach the UN's Sustainable Development Goals (SDG). Referring to the success of the IT industry in the USA, Mowery (2006) and Aghion et al. (2009) propose combining governmental missions (e.g. demandside policies) and sufficient public funding to achieve underlying market-shaping strategies. Acknowledged by over 50 governments worldwide, an increasing number of countries have implemented either dedicated bioeconomy strategies or incorporated bioeconomy-related strategies into their policy (GBC 2018; OECD 2018). The German government is pursuing the goal of assuming a pioneering role in this development and has therefore designed a mission-oriented programme to gain early mover advantages in anticipated technologies. ${ }^{1}$

Although the situation looks promising at this initial stage, the establishment of a bio-based economy is anything but certain. With all the advantages that come from the holism of the bioeconomy concept, there are some idiosyncrasies which illustrate the differences between previous mission-oriented approaches and the identified bio-based

\footnotetext{
${ }^{1}$ One needs to take into consideration that dissimilarities between conceptions of bioeconomy ideals and the multi-facetted nature of bio-based economies result in differing foci of programme designs. For instance, the interpretation of the German NFSB, originating from the biotechnology funding scheme, is an integral component of the 'Hightech-Strategy' and points to a pronounced technology-driven conception of the biobased economy and might overlook the ecological limitations of the concept (Hausknost et al. 2017).
} 
transformation. First and foremost, the most apparent distinction when compared to path-forming policies, which are already occurring and have been evaluated, is the character of the targeted objective. Most preceding policies were aimed at specific technologies, both those which were successfully realised such as biotechnology (Lazonick and Tulum 2011), NASA's space-projects (Mazzucato 2014), Cleantechindustries (Jacobsson and Lauber 2006) or failed attempts such as supersonic aviation (Concorde) (Mazzucato 2014) or magnetic levitation trains (Transrapid) (Büllingen 1997). The bioeconomy, however, endeavours the transformation of the entire oilbased economic system and thus affects different sectors, technologies and knowledge bases. Therefore, in order to attain this objective, solutions are required that go beyond single trajectories. Thus, there is a demand for conjunctions between multiple, previously only loosely linked, paths (Tödtling and Trippl 2018). Moreover, since the imperative of the identified economy is derived predominantly from negative externalities, many markets still need to emerge in the first place. In essence, past technology policies were based on clearly defined and pegged technological targets with previously known markets and, in many cases, with the state itself as the biggest customer. In contrast, GSCs in general and the bioeconomy in particular are characterised by their complexity as well as a lack of both precise targets and consumers (Frenken 2017; Schot and Steinmueller 2018).

In addition, history has proven that the transition of energy regimes has invariably been an arduous and slow process (Philp 2018). While Frenken (2017) states that mission-oriented strategies ordinarily take 5-10 years, the relevant policy strategies cover even longer time frames, i.e. 20 years. In order to achieve the self-imposed targets it is imperative that the mission will not suffer in terms of its implementation or even be terminated after changes of government. At present, the bioeconomy is still gaining momentum on a global scale, nevertheless a long-term commitment is not invariably made due to (geo)political developments. In contrast, innovation policy aspirations often underlie a discursive process and, as a result, require broad public acceptance (Cantner and Pyka 2001). In this respect, the bioeconomy seems to have difficulties with public relations. The broad population, save for a small set of professionally affected communities, is not aware of the politically-induced leitmotif. However, the bio-based industry has the basic prerequisites to involve the entire economic system, i.e. producers and consumers in all aspects, and therefore, it demands communication with and the sensitisation of the public (Dietz et al. 2018).

Another crucial aspect for the bioeconomy's success and a frequently raised objection is the feasibility of strategy implementation in terms of capacity limits. In other words, is it viable to substitute fossil resources with renewables, develop novel products consisting of biomass and, at the same time, meet the paramount goal of securing the food supply for the increasing global population without exploiting and irreversibly damaging the ecosystem (Priefer et al. 2017)? On the basis of this issue, the underlying argument about the government's 'pretence of knowledge' (Hayek 1975) becomes clear and calls into question the identified future system. That is to say, any identified strategy not only carries the risk of not being the most efficient solution, but rather entails the danger of aggravating the current market-failure. For instance, the advancement of genetically modified organisms (GMOs) is eminently contested. There are numerous severe concerns about the intensification of this technology, which is why the EU, amongst others, has rigid restrictions against genetically modified 
foodstuffs (cf. precautionary principle). There is a possibility that a new trajectory is created which exacerbates prevalent problems or generates novel ones (e.g. lead in fuel or CFC in refrigerators). Another example is the increasing production and processing of biological substances, which could lead to rebound effects caused by overcapacity and, eventually, intensify conflicts over land use. As a consequence, serious concerns have been raised about whether the bioeconomy is the optimal solution for the current problems or if, eventually, the market will develop the most efficient solution by itself (e.g. utilisation of hydrogen or the like) (Friedman 1982[1962]).

\section{Political interventions to foster bioeconomy in Germany at the programme level}

By looking at the previously depicted development of the bioeconomy, it becomes clear that the discourse surrounding biological research has changed substantially in the last 20 years. Before the turn of the millennium, both nationally and globally, biotechnology was one focus of mission-oriented policies. However, a trend towards the bioeconomy has been established in the political dialogue since 2004 (Patermann and Aguilar 2018). This acknowledged shift of approaches offers the opportunity to get insights into recent mission-oriented policymaking and allows to track the evolution of a current strategy that gets increasing recognition globally. Future research is encouraged to check whether the bioeconomy is an atypical case with an evolutionary structure or whether other missionoriented strategies (e.g. the Quantum Technology Strategy or the most recent Hydrogen Strategy) follow a similar pattern. For this reason, we now provide a brief historical background of past and present bio-themed funding programmes in Germany.

Pioneering endeavours in Germany to promote biotechnology date back to the period around 1970 (Warmuth 1991; BMBF 2011; Schüler 2016). Most funding in biotechnology largely favoured basic research by public institutions and was aimed at the generation of scientific knowledge (Warmuth 1991). By establishing the innovation system approach in policies, the first systematic, regional funding strategy to commercialise biotechnological procedures was launched in 1995 (Cooke 2008; McCann and Ortega-Argilés 2013). As one of the earliest examples, the BioRegio contest was carried out by the German BMBF from 1997 to 2005 and supported the biotechnology sector in the four winning regions (Staehler et al. 2006). This political programme aimed to initiate a cold start in order to lift the lagging biotechnology sector in Germany and make it competitive and eventually, to have the leading biotechnology industry within Europe (Dohse 2000).

Subsequently, further programmes (i. a. BioProfile, BioChance, BioFuture) were addeded in order to continue this mission-oriented place-based ${ }^{2}$ approach (Eickelpasch and Fritsch 2005; Cooke 2007; BMBF 2017d). In 2001, the BMBF introduced another funding measure ('Rahmenprogramm Biotechnologie' - 'Framework Programme Biotechnology' (FPB)) to not only foster biotechnology independent of the location (in contrast to

\footnotetext{
${ }^{2}$ BioProfile was a contest between regions that could apply with a special profile for biotechnological procedures (Staehler et al. 2006). The three winning regions were the network of Brunswick, Göttingen \& Hanover, the network of Berlin \& Potsdam and the network of Stuttgart, Tübingen, Esslingen, Reutlingen \& Neckar-Alb. BioChance and BioFuture did not have a focus on specific regions.
} 
BioRegio and BioProfile), but also biosciences in general. Eventually, starting in 2010, this programme merged into the 'Nationale Forschungsstrategie Bioökonomie 2030' - 'National Research Strategy Bioeconomy 2030' (NFSB), which is carried out by 6 Federal Ministries $^{3}$ who jointly promote and fund the holistic bioeconomy concept (Hüsing et al. 2017). Afterwards, this scheme resulted in additional specific programmes, e.g. the 'Roadmap Bio-refinery' in 2012, and the 'National Policy Strategy on Bioeconomy' of the BMEL in 2013. Moreover, the coalition agreement of 2018 determined that the bioeconomy vision called 'Von der Biologie zur Innovation'-_From biology to innovation' ('Bio-Agenda') would be pursued further instead of specific biotechnology support (Bundesregierung 2018b; BMBF 2020). In 2020, the Research and Policy Strategies were bundled to form an overall strategy (BMBF and BMEL 2020). For an overview of the dedicated bio-related strategies, see Table 1. Evidently, the German policy has altered over time from a focus on a specific technology towards a scheme aimed at tackling GSCs (Hüsing et al. 2017). Yet, this policy development pattern did not take place exclusively in Germany; it was rather a global process (OECD 2018).

The foci of the drafted programmes differed significantly. For instance, BioRegio aimed at the emergence of dedicated biotechnology firms and contained predominantly start-up financing of private companies to initiate a cluster building process. BioProfile's measures, however, targeted public institutions in order to broadly fund biotechnology-related basic research in the regions' respective profile areas (Staehler et al. 2006; Dohse and Staehler 2008). The subsequent FPB targeted a wider range of grantees within the biosciences, whereby the primary focus was still biotechnology. This framework supported R\&D in public institutions and private projects almost equally with $44 \%$ and $38 \%$ of the overall promotion fund respectively (BMBF 2011).

The bioeconomy strategy instruments, however, cover an extensive spectrum of technologies, sciences and industries due to the holistic character. The actual number of funding lines increased with the implementation of the NFSB and a wider spectrum of topics were covered. For instance, because the government aspired to include several industries, it introduced the measure 'Bioeconomy as societal change' to address the underlying socioeconomic challenges such as the systematic monitoring of bioeconomic processes or communication with the public (PTJ 2020). Other suitable measures to achieve the intended linking of sectors are the governmental incentives 'Innovation spaces Bioeconomy' which does not have any specific core branch and 'Agrarian systems for the future', which approaches the issue of agriculture as a whole (PTJ 2020).

The German cabinet identified and determined five fields of action within the NFSB, in which a sustainable economy oriented towards the natural cycle of materials was to be established (BMBF 2010). Hüsing et al. (2017) illustrated the differing priorities of the strategy in an in-depth evaluation of the measures undertaken within the programme. They found that the field of action 'Industrial utilisation of renewable resources' in particular has the greatest significance within this scheme. Less attention is paid to the following three fields of action: 'Securing global food supplies', 'Sustainable agricultural production' and 'Production of healthy and safe food'. The promotion of the core issue 'Biomass-based energy

\footnotetext{
${ }^{3}$ Under the leadership of the BMBF, the following federal ministries are responsible for implementation: Ministry of Economic Affairs and Energy (BMWi), Ministry of Food and Agriculture (BMEL), Ministry of Environment, Nature Conservation and Nuclear Safety (BMU), Ministry of Economic Cooperation and Development (BMZ) and the Federal Foreign Office (AA).
} 
Table 1 Milestones of bio-themed funding in Germany

\begin{tabular}{|c|c|c|c|}
\hline $\begin{array}{l}\text { Leit- } \\
\text { motif }\end{array}$ & Time-period & Funding Programme & Purpose \& Implementation \\
\hline \multirow{5}{*}{ 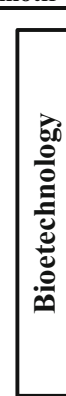 } & $1979-1983$ & 'Benefit plan Biotechnology 1979-1983' & $\begin{array}{l}1^{\text {st }} \text { programme to foster narrowly } \\
\text { defined biotechnology }\end{array}$ \\
\hline & $1985-1988$ & 'Applied Biology and Biotechnology' & $\begin{array}{l}\text { Mainly basic research in } \\
\text { biotechnology }\end{array}$ \\
\hline & $1997-2005$ & 'BioRegio' & $\begin{array}{l}\text { Fostering biotechnology in four } \\
\text { regions }\end{array}$ \\
\hline & $1999-2007$ & 'BioProfile' & $\begin{array}{l}\text { Fostering biotechnology 'profiles' in } \\
\text { three regions }\end{array}$ \\
\hline & $\begin{array}{l}2001-2010 \\
\text { (into NFSB) }\end{array}$ & 'Framework Programme Biotechnology' & $\begin{array}{l}\text { Fostering Biotechnology and related } \\
\text { biosciences }\end{array}$ \\
\hline \multirow{5}{*}{ 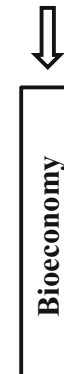 } & $\begin{array}{l}\text { since } 2006 \\
\text { (continued 2014) }\end{array}$ & 'Hightech-Strategy' & $\begin{array}{l}\text { Prioritisation of innovations; including } \\
\text { non-technical solutions since } 2014\end{array}$ \\
\hline & $2010-2020$ & $\begin{array}{l}\text { 'National Research Strategy Bioeconomy' } \\
\text { connected to the Hightech-Strategy }\end{array}$ & $\begin{array}{l}\text { Conceptualisation of a bioeconomy in } \\
\text { Germany }\end{array}$ \\
\hline & $2013-2020$ & 'National Policy Strategy Bioeconomy' & $\begin{array}{l}\text { Connecting multiple policy areas in } \\
\text { the bioeconomy framework }\end{array}$ \\
\hline & since 2019 & 'Innovation spaces Bioeconomy' & $\begin{array}{l}\text { Fostering four selected regions within } \\
\text { the bioeconomy scope }\end{array}$ \\
\hline & since 2020 & $\begin{array}{l}\text { 'National Bioeconomy Strategy' - } \\
\text { Bundling Research and Policy Strategy }\end{array}$ & $\begin{array}{l}\text { Pursuit of a mutual } \\
\text { 'Bio-Agenda' }\end{array}$ \\
\hline
\end{tabular}

Source: own draft according to BT 1990; Warmuth 1991; Staehler et al. 2006; BMBF 2011; Schüler 2016

sources' is almost negligible. Further funding measures favour the development of crosssectional technologies or the assistance of SMEs and the formation of companies (Hüsing et al. 2017). It is apparent that the origin of the strategy, which lies in biotechnology, remains an essential pillar and reflects the claim of the German government that it conducts technology-oriented and innovative R\&D. In fact, twelve out of the 36 evaluated funding measures were initially a component of the former FPB (Hüsing et al. 2017). This is not extraordinary since biotechnology, labelled by the EU as 'key enabling technology', is presumed to be a driving force behind innovative processes in all upstream and downstream parts of the bioeconomy according to political thinking and thus, functions as an interdisciplinary technology that can be applied in the entire bioeconomy (BMBF 2010; EC 2012).

While the advancement of biotechnological solutions seems to be paramount considering the past and current governmental strategy for action, one key issue is the lack of diffusion of new knowledge into marketable products (Hüsing et al. 2017). Apart from extensive SME subsidisation and start-up financing, the policy seldom aims to achieve this crucial element, which simultaneously highlights the problematic nature of missing markets. Moreover, the aspect of ecological sustainability seems to be only implicitly addressed by technological advances at various levels. In fact, no explicit environmental protection measures were integrated into the framework of public funds. The same applies with regard to the matter of insufficient (governmental) demand for bio-based solutions.

In conclusion, it can be said that the innovation policy strategy has developed dynamically on paper. Initially, the focus was exclusively on biotechnology. This thematic focus, however, expanded gradually due to altered preconditions, became increasingly extensive, and eventually led to the bioeconomy concept. Thus, there was no distinct event that 
terminated the biotechnology funding and afterwards launched the bioeconomy strategy. This process resembles an evolution, in which the focal point biotechnology remained constant and policy changes happened as a consequence of changed circumstances.

Considering this development, we also aim to evaluate, at project level, the actual implementation of the strategies. To be able to conduct this analysis, a clear understanding of the bioeconomy concept as well as a meaningful dataset are necessary. After delineating the structure and definition of the bioeconomy for the analysis, the data provenance and preparation will be described in the following chapters.

\section{Structure of the bioeconomy}

Due to the lack of a uniform and tangible bioeconomy comprehension, it is necessary to find a coherent definition for the bioeconomy concept that is suitable for the empirical analysis. Therefore, we gathered data and conceptions from various actors involved with the bioeconomy concept and systemised their opinions within a breakdown of the bioeconomy along the value chain. Since the bioeconomy is 'largely driven by policy action and the contents of bioeconomy strategies worldwide' (Viaggi 2016, p. 105), the political vision has determined our definition to a large degree (see Table 6 for the sources). Thus, the derived definition has a broad range, similar to the German strategy paper NFSB. We propose a breakdown into four pillars: the input, processing and output dimension as well as a socio-economic framework (see Table 2).

Although experts and literature differentiate some components of the bioeconomy in more detail than proposed, for the sake of a sensible interpretation we pooled some related subdivisions. For example, green biotechnology is closely connected to agriculture and often involves the research and breeding of plants and crops as well as animals and livestock. Blue biotechnology, however, which deals with the processing and utilisation of biological resources from marine habitats such as algae and fish, is defined solely by the aquatic origin of its resources (EC 2012; Zinke et al. 2016), and shows major structural overlaps with green biotechnology. For that reason, we combined these two segments.

Furthermore, while the other segments of biotechnology can be clearly demarcated and assigned to a specific industrial sector, the white biotechnology (or industrial biotechnology) concept is rather blurry. The common definition is the utilisation of biological resources within industrial processes and products (OECD 2009). Consequently, its application area is extremely wide and contains, for instance, the creation of innovative processes and technologies to provide biological basic material (e.g. instead of plastic) or to identify, extract and produce substances from or with organic substances within various industries. Another example is the application of microorganisms in sewage treatment plants during the purification process. It becomes clear that the scope of white biotechnology is quite large (BMBF 2010). We also integrated so-called grey biotechnology (environmental procedures) into this category (OECD 2009; Zinke et al. 2016).

Another field of application for the bioeconomy is the production of bio-based products and materials (BMBF 2010; Staffas et al. 2013). Apart from the mere substitution of existing fossil-based products, this pillar includes the development of commodities that fulfil new tasks. Additionally, branches such as the pulp and paper industries also fall into this category (EC 2012; Purkus et al. 2018). 
Table 2 Structure of the bioeconomy

\begin{tabular}{|c|c|c|}
\hline & Dimension & Components/Elements \\
\hline \multirow{7}{*}{ 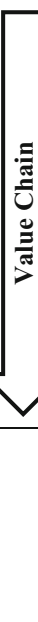 } & Input dimension (production) & $\begin{array}{l}\text { agriculture \& forestry } \\
\text { climate \& environmental protection }\end{array}$ \\
\hline & \multirow[t]{3}{*}{ Biotechnology (processing) } & $\begin{array}{l}\text { green biotechnology (agriculture and aquaculture, e.g. } \\
\text { plant and animal breeding on land and in water) }\end{array}$ \\
\hline & & $\begin{array}{l}\text { red biotechnology (medicine, e.g. biopharmaceuticals, } \\
\text { human genes) }\end{array}$ \\
\hline & & $\begin{array}{l}\text { white biotechnology (industry and environment, e.g. } \\
\text { sewage treatment, new materials) }\end{array}$ \\
\hline & $\begin{array}{l}\text { Output dimension } \\
\text { (material utilisation of biomass) }\end{array}$ & $\begin{array}{l}\text { products and materials } \\
\text { energy \& fuels } \\
\text { food \& feed }\end{array}$ \\
\hline & \multirow[b]{2}{*}{$\begin{array}{l}\text { Socio-economic framework } \\
\text { including non-tangible matters } \\
\text { such as }\end{array}$} & coherent policy \\
\hline & & $\begin{array}{l}\text { viable financing for companies within the bioeconomy } \\
\text { platforms and arrangements for networking } \\
\text { education and qualification } \\
\text { sensitisation of the society }\end{array}$ \\
\hline
\end{tabular}

Source: own conception

Eventually, most stakeholders agree that for a successful implementation of the bioeconomy approach, apart from all fields directly related to biological materials and processes, a socio-economic framework is indispensable. In the case of realising a biobased economy, it encompasses several generic factors like a coherent policy (Dietz et al. 2018), viable financing for companies within the bioeconomy (Viaggi 2016), platforms and arrangements for networking (OECD 2009) as well as the creation of novel professions and their qualification (formas 2012). In addition, bioeconomyspecific determinants are included. These are especially, yet not solely, the sensitisation of the society towards enlightened and conscious thinking/behaviour to trigger sustainable development (Pietzsch 2017) as well as a debate about ethical justifiability (e.g. concerning genetically modified organisms or animal welfare) (McCormick and Kautto 2013). All these features are bundled in the dimension socio-economic framework.

One objective of this study is to trace the transformation from biotechnology towards bioeconomy. Therefore, it is necessary to distinguish between the initial sector-focussed funding, namely the biotechnology sector, and the additional dimensions of bio-related support, which were conceptualised by the bioeconomy strategy. This is why the components of the bioeconomy concept are henceforth categorised and designated as follows (Fig. 1):

- biotechnology nucleus: green, red, and white biotechnology

- bioeconomy shell: input and output dimensions as well as the socio-economic framework

The biotechnology nucleus and the bioeconomy shell jointly represent the bioeconomy concept. 


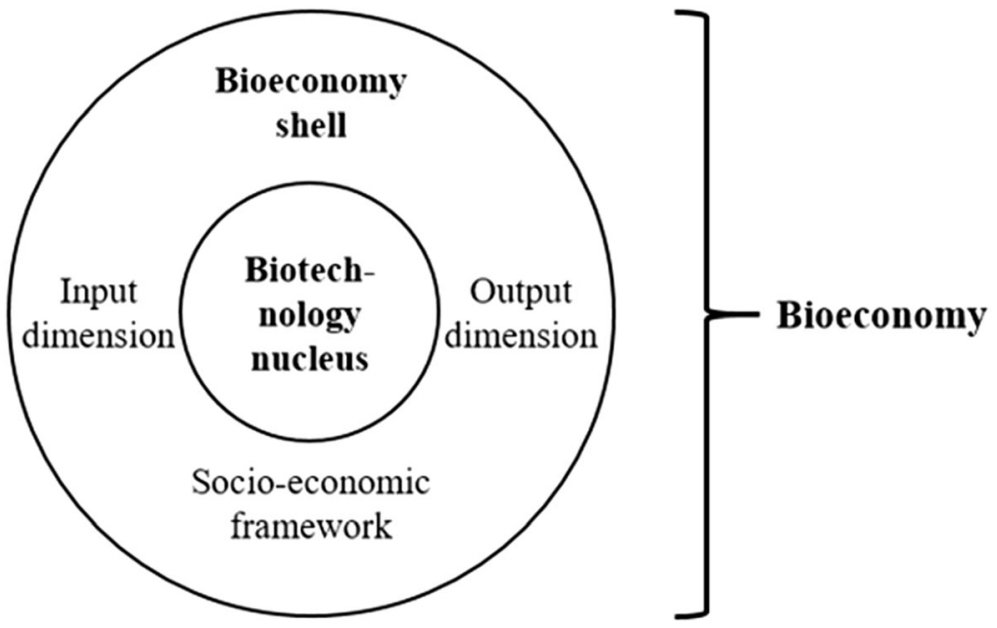

Fig. 1 Illustration of the bioeconomy components and structure. Source: own draft

\section{Data and method}

In order to examine the scope and scale of the actual biotechnology/bioeconomy implementation, we built a distinct database containing all projects funded by the federal ministries, which are recorded in the German funding database called 'Förderkatalog' (BMBF 2017a) ${ }^{4}$. By April 2017, the dataset comprised 191,347 projects with valid information, with the earliest entry being from 1968. The data is structured based on the applied funding measures. This internal BMBF classification is called 'Leistungsplansystematik (LPS) - Benefit plan systematics' and has superordinate topics such as 'A-Health research and health economy', 'D—Food, Agriculture and Consumer Protection' or 'E-Energy research and technologies'. This classification is refined by two further tiers. Eventually, bioeconomy R\&D is aggregated in its own category: 'BBioeconomy'. However, there are two issues which need to be taken into account during the analysis. On the one hand, the segment ' $\mathrm{B}$ ' includes projects that date from far before the official bioeconomy policy concept was formulated - the first record in this category is dated 1968, whereas the start of the bioeconomy strategy was in 2010. On the other hand, it is apparent that numerous topics or projects within several other classes such as 'EB1920 Energetic use of biomass', 'GC2060-Organic electronics' or 'KA1210 Nanobiotechnology' can clearly be assigned to bioeconomy, but are not covered by this class. For that reason we considered it necessary to integrate all these projects that actually

\footnotetext{
${ }^{4}$ According to a statement by the BMBF, the database contains approximately 95 percent of all R\&D projects funded by their ministry (with an increasing tendency). However, it is the responsibility of the other departments (e.g. Federal Ministry of Food and Agriculture, Federal Ministry for Economic Affairs and Energy) to record their projects and the data suggests that only a fraction of the ministries' projects have been entered into the database. However, the BMBF is not only in charge of implementing the biotechnology and bioeconomy strategies, but also accounts for approximately $58 \%$ of total R\&D expenditure in Germany (BMBF 2017c) and therefore, is responsible for the lion's share of all funding. Thus, this database is sufficient in order to make empirical statements about the knowledge-driven bioeconomy funding landscape.
} 
operate in the scope of the bioeconomy approach, including projects outside of the category 'B-Bioeconomy'.

The database 'Förderkatalog' is openly accessible and offers valid information about the temporal horizon, the monetary investment, the names of the grantees as well as the executing organisation along with their respective locations and also information about the collaboration partners in the case of joint projects. We diagnosed two types of information about each undertaking's topic which were most relevant for the identification process. In addition to the BMBF's internal classification (LPS) that gives explanations about the subject area, the title of the project provides genuine indications about the project's content.

Given these circumstances and based on the BMBF classification ${ }^{5}$, we first categorised the dataset into three divisions on the basis of comprised projects and further derived statistics per LPS(see Fig. 3), namely:

[i] classes that were ascertained to belong to the bioeconomy,

[ii] classes that only partially belong to the bioeconomy and

[iii] further categories that are unlikely to contain bioeconomy projects ${ }^{6}$.

Consequently, with common text-mining techniques (e.g. removing whitespaces and stopwords, converting to lower cases) the project titles were simplified. Considering the main principle of the bioeconomy, namely the involvement of biological materials and processes, it is, in our opinion, an appropriate measure to draw on this basic idea and hence to create a collection of biomass-connected terms and expressions. For that reason, we detected all phrases that belong to biological substances and processes that appeared in at least five project titles and had a unique stem within division [i]. The result was a set of 374 terms (see Table 7). With this array of phrases, we calculated the amount of bioeconomyrelevant terms in each project title to identify relevant projects in [ii] and [iii]. Using these calculations, after gradual refinement of the adjusting parameters, we applied a step by step procedure to select projects relevant to the bioeconomy:

1. Classification of subdivisions from the funding database with regard to their relatedness to the bioeconomy. As a part of this classification, all projects from the subdivision [i] were selected and added to the database.

2. Application of distinct thresholds ${ }^{7}$

a. Within division [ii], we chose all projects that featured at least two keywords.

b. Due to certain bio-related projects in unanticipated classes [iii], the counting threshold value was set to four.

In order to categorise the bioeconomy projects into the dimensions mentioned above (see Table 2), we determined groups within BMBF's internal classification (LPS), which are clearly assignable to one of the previously determined bioeconomy sections along the

\footnotetext{
${ }^{5}$ It should be noted that this internal system is constantly reviewed and thus, retroactively changes over time.

${ }^{6}$ We excluded the funding area 'C - Civil security research' entirely, as biological warfare agents are not part of the bioeconomy notion.

7 Through repeated experimentation, it became clear that the choice of threshold values of two and four proved to be the most sensible. The reduction to lower thresholds involved too many projects that were not in the bioeconomy scope. When the threshold value was lifted, too many relevant projects were excluded.
} 
value chain. A significant proportion, however, had to be attributed by hand, which also served as a result review and occasionally led to the identification of projects which did not fit and were subsequently eliminated from the database. Table 8 displays the entire BMBF classification in which the categorisation of the bioeconomy concept is described in more detail. Furthermore, a schematic visualisation of the dataset building process is depicted in Fig. 2. Even though the database covers projects dating back to 1968, the analysis is limited to a time frame from 1995 to 2015. In Germany, the change within bio-themed funding towards the bioeconomy officially begun with the launch of the bioeconomy strategy in 2010. While the historical development of biotechnology funding before 1995 could offer interesting insights, the focus of this study is on more recent trends. By employing this method, 16,500 projects within the observation period could be identified as relevant to the bioeconomy and were included in the final dataset. Table 3 lists the basic descriptive statistics of the data.

\section{Results: public funding of the bioeconomy at project level}

In the following, the prepared project data will be analysed. Initially, we will give an overview of both the general development of the bioeconomy and the overall funded R\&D projects. Subsequently, the structural change within the bioeconomy will be presented before the individual subclasses are examined more closely.

As has been established, the issue of the bioeconomy is increasingly attracting attention in political agendas on a global scale. While it is evident that there is a rise in bio-related strategies at a programmatic level as well as a thematic expansion, this change is less clearly evident in terms of distinct bioeconomy projects. ${ }^{8}$ Although the number of projects related to the bioeconomy more than quadrupled from 316 in 1995 to 1.374 in 2015, the proportion in relation to the overall amount of projects only increased slightly (see Fig. 3). The share oscillated between approximately 12 and 13 percent during the initial years of the BioRegio funding until 2003. After two steep rises to almost 20 percent of all funded R\&D projects in 2004 and 2007 respectively, it has levelled off at 14 to 15 percent in recent years. Notably, there was no detectable growth in the share of bio-related R\&D with the introduction of the bioeconomy strategy and the connected funding measures in 2010.

However, due to the depicted structural changes in bio-related innovation policy accompanied by the successive inclusion of a broader scope of decisive sectors, we find there was a shift within the funding of the bioeconomy. Therefore, we split the dataset into biotechnology core and bioeconomy shell (see Fig. 4). In the first years of our observation period, three quarters of all bio-related research was in biotechnology, dominated by red biotechnology. Until 2006, the general development was characterised by fluctuations without a persistent trend. From that point on, we found a significant increase of R\&D beyond solely biotechnology. Eventually, in 2012, in the third year after the introduction of the bioeconomy strategy (NFSB), the number of projects in the biotechnology core was for the first time smaller than in the bioeconomy shell. Hence, the data suggest a transition of funding associated with the alteration of strategy at a programmatic level. Nevertheless, two aspects must be taken into account in this context. Firstly, while we find a clear structural

\footnotetext{
${ }^{8}$ A project is only counted in the year of its beginning. As such, each project is considered only once in the following analyses.
} 


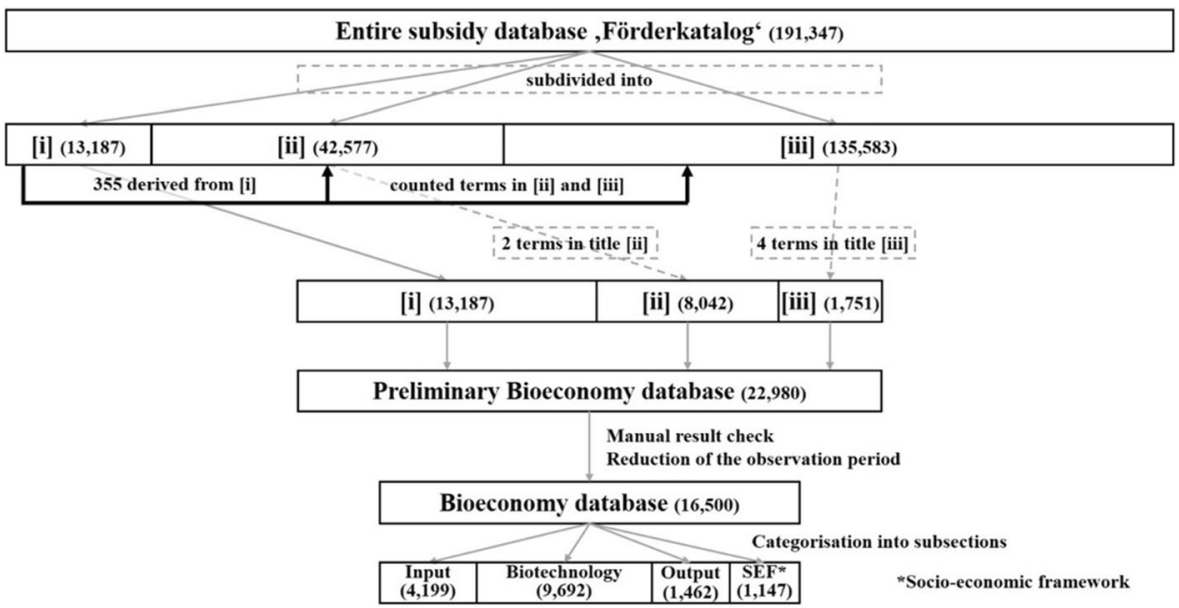

Fig. 2 Schematic process of the database derivation (not proportional). Source: own draft

transformation within bio-related support, as previously stated the proportional share of all the projects funded in Germany did not increase significantly. Secondly, the tangible change towards a biotechnology-transcending scheme at project level started roughly in 2007, possibly even in 2001, whereas the NFSB was not established until 2010. Thus, the trend towards more general bioeconomy funding was already implicitly addressed by several other funding measures (mostly driven by grants for sustainable agriculture \& forestry as well as R\&D in biomass-based energy \& fuels). However, a great leap in favour of bioeconomy R\&D activities as a consequence of the NFSB did occur in 2012. This somewhat delayed response can be explained by two facts. First, the transition from a biotechnology strategy towards a bioeconomy strategy proceeded fluidly, in which one third of all funding measures originated from the former 'Framework Programme Biotechnology'. Secondly, each step of the process, from the announcement of the strategy to the preparation of specific funding programmes, the submission of project applications, revisions etc. up to the final project start, takes months or sometimes years.

As the structural changes within the bioeconomy sectors reveal more detailed information about the transition than the mere number of funded projects, a breakdown of these developments is illustrated in Table 4 . The most obvious structural change to the

Table 3 Comparative figures of the funding datasets (1995-2015)

\begin{tabular}{lll}
\hline & Full database & Bioeconomy \\
\hline Number of projects & 114,448 & 16,500 \\
Average funding per project in $€$ & 546,911 & 426,936 \\
Median funding per project in $€$ & 208,685 & 235,916 \\
Average project duration in days & 995 & 1,118 \\
Median project duration in days & 1,095 & 1,095 \\
Share of joint projects & .59 & .72 \\
Share of public organisations & NA & .66 \\
\hline
\end{tabular}

Source: own calculations 
bioeconomy funding is the steady increase of agriculture \& forestry funding. At the same time, the share of support for red biotechnology dropped noticeably by 19 percentage points between the start and end of the observation period. The sector agriculture \& forestry ultimately became the most funded area within the bio-based economy (based on the project count). The main driver for the conspicuous growth in significance is the involvement of the BMEL. From 2002 on (except 2005), the BMEL funded the majority of the R\&D projects within agriculture \& forestry. The $\mathrm{BMBF}$ is by far the most relevant funding source in most other areas (with the exception of energy \& fuel). This illustrates the character of the bioeconomy, in which different departments are planned to deal with this subject. Two broadly defined categories were responsible for the steep increase: Between the years 2002 and 2011 the majority of projects in this sector were financed in the field 'Sustainable agriculture, horticulture, forestry, fisheries and food industry; development of the potential of renewable raw materials'. Since 2012, the main driver has been 'Studies on the emergence of wood and agricultural biomass, on the mobilisation of utilisation and production reserves and on increasing the use of wood and agricultural raw materials, including new production processes and products'. The BMBF had only one funding line in agriculture and forestry that featured somewhat greater aspirations: 'Research for a future-oriented forestry'.

The second subclass of the input dimension, climate \& environmental protection, was one of the most frequently considered pillars and after losing some relevance during the 2000s, it has been focussed on incrementally more since 2010 . This funding, however, stems from various measures and, unlike agriculture \& forestry, does not concentrate on a specific support line.

Over time, the funding share of biotechnological projects, as previously established, has become much less significant. Green and white biotechnology have remained quite stable at about ten percent (except for 3.4\% in 2013-2015) and between 15 and 20 percent respectively. In contrast, only roughly half of the projects in red biotechnology were financed in the latest time period compared to previous funding. In green biotechnology, most R\&D-projects were promoted with a focus on plant research. Naturally, in white biotechnology many undertakings are related to industry and are found within LPS such as 'BioIndustry 2021', 'Biotechnology 2020+' or specifically in 'Optical technologies for lighting and environmental protection' or 'Analytics - Sensors, measurement methods and models'. Analogous to this, R\&D in health dominates funding in red biotechnology. First and foremost, projects in the field 'Systems biology' have the biggest share throughout the whole observation period. More recently, funding of SMEs and thereby a bigger focus on specific market solutions can be perceived. One needs to bear in mind that the overall amount did not decline (on the contrary, project numbers in the red biotechnology almost doubled from 483 to 916 between the first and last time period shown), but other bioeconomy sectors have recorded more significant increases in terms of the number of projects.

The subclasses of the output dimensions generally fluctuated at a low base level except for energy-related projects. This outcome reflects and confirms Hüsing et al.'s (2017) and Frenken's (2017) findings that there is a lack of clear markets and customers for bioeconomy products. Projects to develop bio-based products or materials have had some peaks, resulting from temporary funding measures such as 'Identification and investigation of marine natural substances' or 'Integrated environmental protection in the timber and furniture industries', but did not receive persistent research grants. Interestingly, energy \& fuels from biomass is the only segment of all classes in the output pillar that shows a slightly positive development in terms of the project count. Contradictory to Hüsing et al. (2017), who identified the field of 


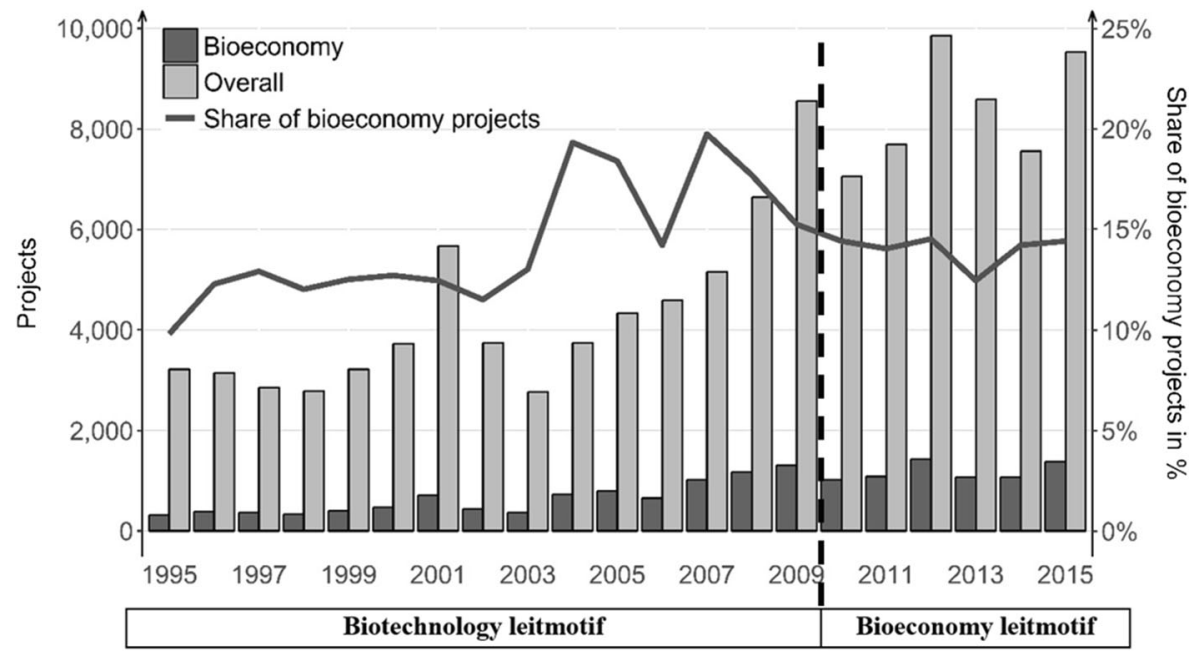

Fig. 3 Funded projects in Germany (1995-2015). Source: own calculations

action 'Biomass-based energy sources' as being neglected in terms of public R\&D, we find a rise from zero projects in 1995-1997 to around 200 each in the last three time periods. As mentioned before, this segment differs slightly from the others, as more than half of the R\&D funding are derived from the Federal Ministry for Economic Affairs and Energy. 'Energetic use of biomass' and 'Basic energy research' are the categories with the most undertakings within this category. R\&D in food \& feed industries only had a very limited share of the bioeconomy funding in the past. Even the topic 'Global food supply', which is mentioned in the NFSB as being a principal goal of all those stated in the NFSB, only had 14 and 42 projects financed in 2012 and 2013 respectively and funding stopped in the following years.

Although measuring the socio-economic framework has never been done in previous attempts to assess the scope of the bioeconomy, we identified a not insignificant allotment of funded projects in this pillar. Between 1996 and 2000, this was mainly

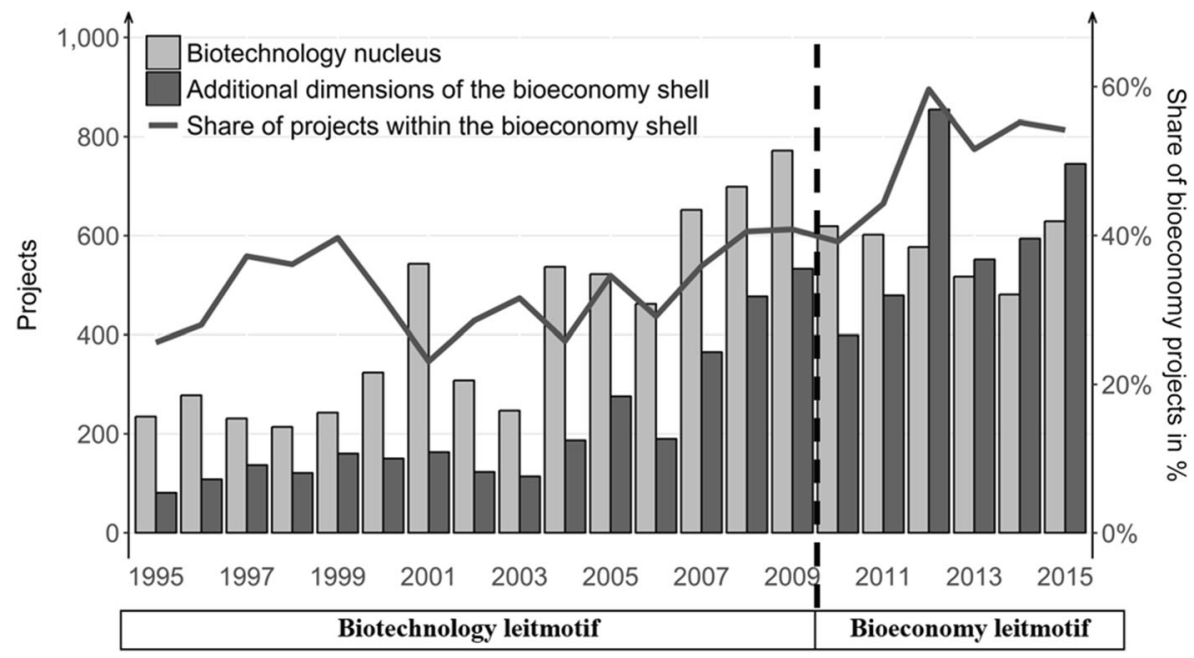

Fig. 4 Comparison between bioeconomy and biotechnology funding (1995-2015). Source: own calculations 


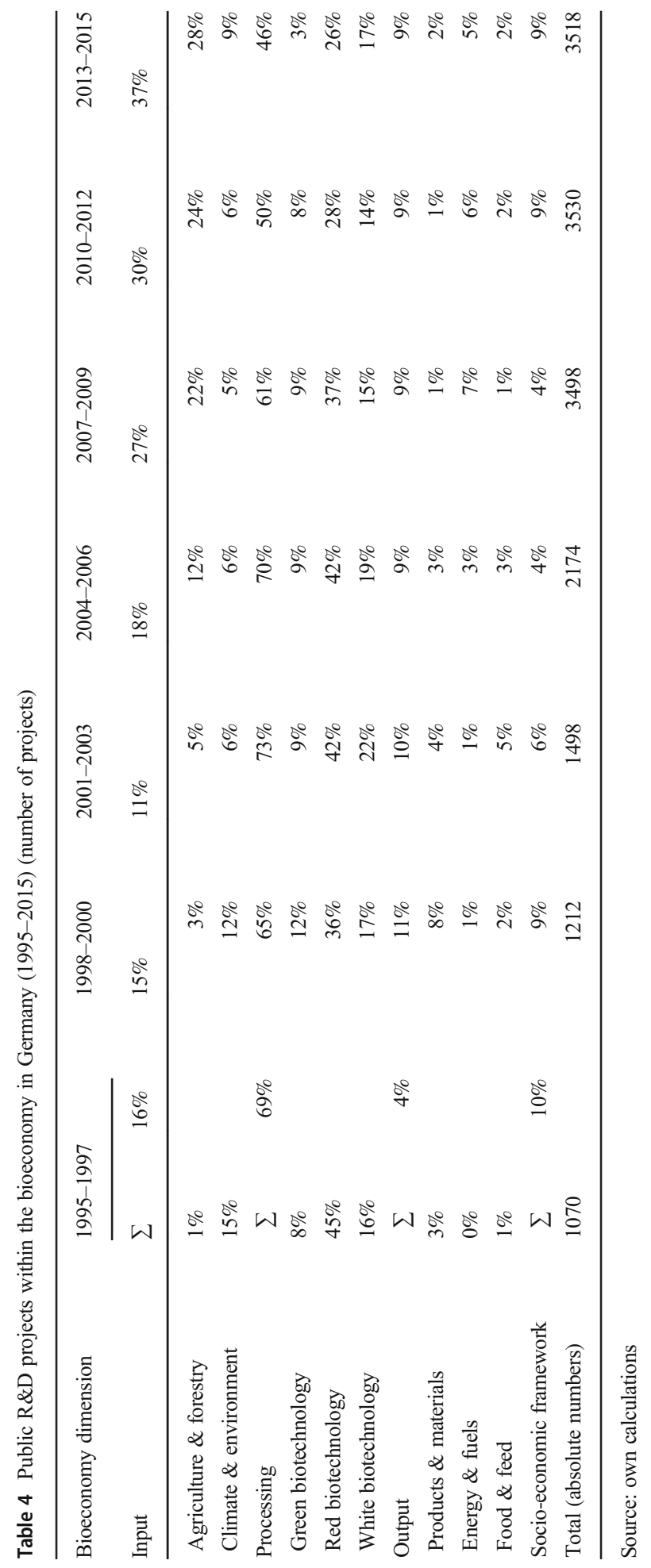


driven by the BioRegio-Contest, in which e.g. network activities were fostered between firms and institutions. After a loss in relevance from 2001 to 2011, inter alia, investments in international cooperation and further exchange opportunities for scientists (via scholarships) have received considerable support, indicating the significance attributed to this issue. Subjects like animal welfare, general infrastructure or social-ecological research still appear less frequently, but have become more apparent in recent years.

To gain a more complete or differentiated understanding of the bioeconomy funding in Germany, the monetary dimension has to be considered as well. In Table 5, it can be seen that the overall development follows the same trend as the project count, yet in different magnitudes, i.e., R\&D projects to promote biotechnological processes receive more financial support on average than projects in the input, output dimensions and also more than those in the socio-economic framework. While this can generally be explained by the costintensive equipment used in biotechnology, we also find that red biotechnology is the predominant driver for this issue. It is only within the more recent time intervals that green and white biotechnology were issued more funding than projects in relative terms. Apart from that, it is interesting that $R \& D$ projects in climate \& environment have a bigger monetary share than their share by the project count. In every other category at almost any other time period, the project number is equal to or higher than its financial stake.

In essence, public funding of bio-related R\&D projects co-evolved gradually with programmatic changes. A rise in projects related to the bioeconomy shell became visible well before the introduction of the NFSB in 2010. This gradual change started already around 2001 and a further marked rise of funding in the bioeconomy shell occurred in 2012 with a delay of two years after the introduction of the NFSB. The significant decline of projects in red biotechnology since 2010 in favour of R\&D in agriculture and forestry, mainly driven by the involvement of the BMEL, as well as investments in undertakings related to the socio-economic framework of the bioeconomy, has been most apparent. Most pillars do not follow a consistent trend and fluctuate around a certain value, whereas much less attention has been paid to the output dimension. The biotechnology core still plays a very important role, which can be traced back to the funding history in Germany and the special role attributed to biotechnology as key enabling technology (KET).

\section{Discussion}

In the analysis, we used a broad definition of the bioeconomy, which made it possible to supplement preceding bioeconomy research and to overcome existing drawbacks regarding both a detailed definition and meaningful data (cf. e.g. Bugge et al. 2016; Pietzsch 2017; Wesseler and Braun 2017). These data revealed a steady increase from 316 funded projects in 1995 to 1,374 in 2015. However, in the same time period the growth in the overall amount of funded projects advanced at almost the same rate, which is why it is not possible to speak of a clear prioritisation of bio-related R\&D. The argument that priorities and, accordingly, public governance are shifting to an extent that one sector or branch is massively promoted or neglected cannot be confirmed here. Nevertheless, we found a considerable structural change within the bioeconomy R\&D funding at the expense of red biotechnology, which was, amongst others, a focus area of the previously pursued funding schemes. The biotechnology segment was, proportionally, by far the most heeded pillar 


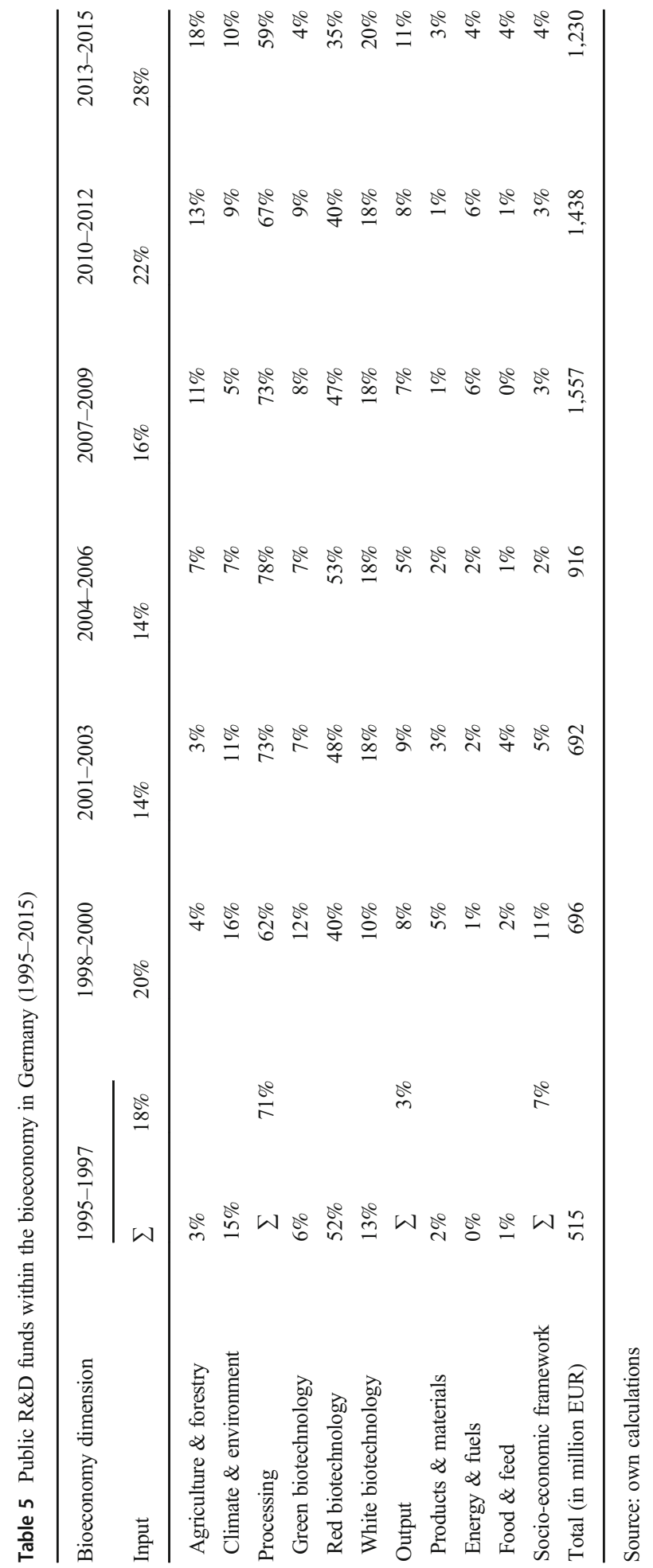


between 1995 and 1997. Due to the shift at the programmatic level and BMEL's growing engagement, biotechnology lost in relative significance in governmentally funded R\&D projects. In spite of this, biotechnological processes still enjoy the most attention in funding programmes and make clear the vision of the Federal Government, whose procedural model consists of solving emerging issues mainly via technological innovations (Hausknost et al. 2017; Bundesregierung 2018a).

Against the backdrop of the debate about new innovation policy approaches, Kattel and Mazzucato (2018) highlight how non-technological innovations have gained value in the third generation of the innovation policy. Apart from technological innovation, one can distinguish between a great variety of innovations within organisations (Damanpour 1991) as well as other concepts such as social innovations (EC 2013). While Grimm et al. (2013) emphasise the great potential of social innovations as a policy tool, McCann and OrtegaArgilés (2015, p. 1299) stress attention to the 'adaption, adoption and diffusion' of existing innovations as an appropriate measure to implement technologies like biotechnology in practice. In view of the relatively recent implementation of such approaches in innovation policy (since 2014 in the German Hightech-Strategy), an evaluation with regard to an adequate quantity and effectiveness is still somewhat premature (Kuhlmann and Rip 2018).

However, the data also reveal that the share of the biotechnology sector diminished over time, which might be an indication of the acknowledgement of facets apart from technological R\&D. The biggest beneficiary of this development is the agriculture \& forestry sector. At the same time, the output dimension's stake as a whole has not significantly increased, which highlights the frequently mentioned issue of missing markets (Hüsing et al. 2017; Frenken 2017). In fact, analysing the share of public grantees over time, we find no clear tendency of an increasing marketisation by private companies. Furthermore, it turns out that the fuel \& energy sector is most frequently promoted within the output dimension in the later phases. The energetic use of biomass, in contrast, is often regarded as the last stage of cascade utilisation with the lowest added value. The debate on the prioritisation of the respective bioeconomy fields is justified at this point (e.g. food or fuel).

Another concern raised is the feasibility in terms of ecological sustainability and capacity limits respectively. While there are objections about the general practicability of a bioeconomy, no dedicated funding measures concentrate exclusively on the substantial issue of climate and environmental protection. Additionally, in the data one can find evidence that this pillar lost significance over long periods and only recently regained attention. This could be explained by the lack of prioritisation, but also because the topic is implicitly addressed in other funding measures assigned to different segments as well as due to its cross-sectional character. The same applies to some aspects of the socioeconomic framework such as the sensitisation of the broad population and the entire societal discourse on the subject. With regard to this issue one does not find an explicit line of support, because it is included more as a cross-sectional field of action in both major strategies of the Federal Ministries (BMBF 2010; BMEL 2014).

Looking at the development at both programmatic and project level, we argue that, in this instance, an innovation policy with a rigid and linear top-down character, in which policy makers determine the direction of R\&D funding in empty space, does not apply. By considering the content and time dimension in political discourse, funding programmes and approved R\&D projects, it is more likely that other mechanisms can be assumed. It shows that funding measures are based on previous and existing strategies, which thereby have an impact on further schemes in future. In other words, the assumption that the 
policymaking process is self-enforcing and evolutionary with several evaluation loops between phases, which are not clearly separated, is more likely to be the case than a strictly government-driven process independent of other determinants. One consequence would be the expectation that the long-term aim of establishing a vital and innovative biotechnology landscape in Germany has led to an early commitment to a dedicated bioeconomy strategy, in which the cross-cutting biotechnology still plays a fundamental role. Hence, the current priority which favours the bioeconomy concept will prospectively also influence forthcoming innovation policies (see Fig. 5).

In conclusion, the criticism of the top-down character of mission-oriented innovation policy might be justified to some extent, but due to the illustrated implementation of a strategy such criticism does not seem to be so well-founded. The data suggest that the implementation resembles an evolutionary process successively driven by a diversity of actors from business, research and other stakeholders (e.g. civil society) who continuously influence the mission or strategy. The advantage of using this approach is that a certain continuity can be achieved, which is conducive to planning and the long-term visions of all concerned actors. However, the question as to whether the 'race chosen and bet placed' was the most efficient choice remains. Moreover, this self-enhancing path-dependent process might eventually lead to a lock-in situation in which a specialisation is achieved that is difficult to overcome.

\section{Concluding remarks and future research}

In the context of this study we have focussed on the multi-faceted subject matter of the changing character of innovation policies as well as the emergence and development of stateselected missions. The applied innovation policy tools have been adapted in line with the zeitgeist and indicate the increasing relevance of holistic perspectives in modern times. However, how missions surface and are subsequently realised in tangible programmes and projects has largely not been elaborated on. Therefore, the aim of this study was to shed light on the efforts and transformation of bio-themed innovation policy in Germany. Due to the diagnosed shift from a mere technology policy towards a trans-sectoral approach, the expounded case allows the reproduction of the sequence of political actions. To capture the dimension of the underlying changeover, we analysed the development in two stages. First, we traced back political interventions at the programmatic level, which aimed at the construction of a leading biotechnology sector and the implementation of a bio-based economy. Secondly, we built a database containing all publicly funded bio-related R\&D projects to identify the development of the measures undertaken.

Overall, it is not possible to draw any final conclusion as to whether and to what extent a critical mass of projects or monetary incentives must be provided in order to assure the realisation of a bioeconomy. Furthermore, it is debatable whether the specification of a direction is necessary or whether other paths induced by the market would guarantee a more efficient and meaningful solution to the EU's GSCs or the UN's SDGs. Nevertheless, past research has shown that a mission-oriented policy has its raison d'être. Particularly in the case of the bioeconomy, it is apparent that economic reasons have not been the sole driver for the innovation policy as was the case for most previous interventions. Instead, ecological imbalances and capacity limits require the commitment of governments to steer and pave future paths.

Through this analysis, we have responded to two deficiencies in the existing literature. Firstly, we are able to show in which way innovation policies occur and 


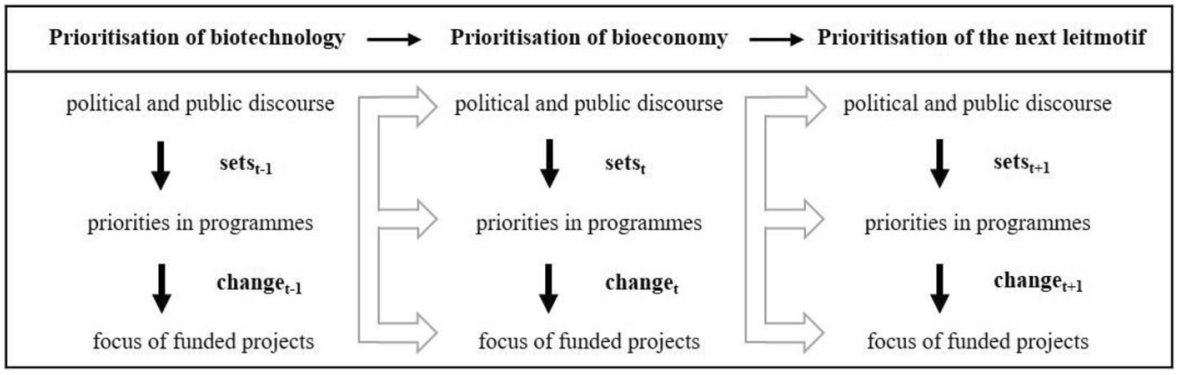

Fig. 5 Hypothetical interdependencies during the evolution of bio-based innovation policy

develop as well as whether and how those policies are implemented through concrete projects. Secondly, while most studies deal with the technological facet of the bioeconomy, topics covering its socioeconomic component are still quite rare. By proposing a classification along the value chain, we acknowledge the comprehensive character of the bioeconomy and suggest a model, in which novel components can be added. Hence, our contribution is a better understanding of the concept and an overview of the general evolution of bio-themed R\&D funding in Germany.

The case outlined is an individual case study. It is therefore conceivable that missionoriented innovation policies may in reality be characterised by strict top-down planning (e.g. for developing countries). Nevertheless, there are good arguments that this process is to some extent similar in other contexts as well. That means, path dependencies might play a key role in other fields of innovation policy as well. Due to a lack of capacities, it is impossible for a single country to specialise in all kinds of technologies and pathways and therefore a certain focus is necessary (Schot and Steinmueller 2018). It is expected that existing structures and knowledge are decisive for future endeavours and that mechanisms of relatedness and branching occur in this respect. In this case it would have been unlikely to foster the bioeconomy concept at a very early stage without the biotechnology efforts of previous decades. The same is also conceivable for strategies in other fields of innovation, which remains a topic for future research. However, the findings must be embedded in the general shift of innovation policies within the last two decades. Since structural changes within mission-oriented innovation policy approaches and the emergence of bioeconomy promotion took place simultaneously and possibly mutually influenced each other, it would be too early to postulate a strict path dependency of missions-oriented policy schemes.

In this study, we one-sidedly examined the input dimension of innovation in terms of R\&D projects in the bioeconomy. Other mechanisms, such as market shaping approaches, have been installed by politics to realise the bioeconomy mission, but are not examined here. Also, further research about actual output is required to get a better grasp of the scope, volume and sustainability of the intended knowledge-based bioeconomy. Furthermore, distinct impact studies to evaluate public endeavours are crucial to assess its ramifications and hence, legitimise the political engagement in anticipated and not yet established fields such as the bio-based economy.

Although we were able to present a more comprehensive image of the R\&D projects that foster the realisation of a bioeconomy in Germany than previous research, there are still concerns that need to be considered. First, the database we used for the keyword search only provided us information about the title of the project. More detailed information about the objective of the individual projects would have created a better foundation for the 
identification of bioeconomy projects. In addition, it should be noted that by categorising the projects into different parts of the bioeconomy, we are able to provide a new perspective in terms of content. Yet some projects cannot be attributed in a clear-cut way. For instance, agriculture and forestry may be closely related to green biotechnology or food and feed industries. Cross-cutting subjects such as climate and environment and the socio-economic framework may also be found jointly in projects that have their core objective in other areas.

While this work addresses the interaction between political rhetoric and the actual translation into corresponding programmes and projects, neither downstream research subjects such as the adoption and evaluation of undertaken policy nor qualitative insights into the individual features were part of the contents of this examination. With our findings, we are able to conclude that there is not a simple linear direction from political discourse that introduces or adjusts programmes and has consequently altered the priorities in projects. However, it is still a matter for further research to determine which factors set which processes in motion or influence them (see Fig. 5) and remains the focus of future (qualitative) research. In these regards, additional studies are required to understand the mechanisms of the policymaking process in general and innovation policy in particular.

Acknowledgements This study was funded by the German Ministry of Education and Research (BMBF) within the framework 'Bio-Economy as Societal Change' (grant number 031B0234B). The authors would also like to thank the two anonymous referees of Review of Evolutionary Political Economy for their helpful comments.

Funding Open Access funding enabled and organized by Projekt DEAL.

\section{Declarations}

\section{Appendix 1}

Table 6 Parts of the bioeconomy considered by policies and academia

\begin{tabular}{|c|c|c|}
\hline Subject and objectives & Dimensions & Source \\
\hline $\begin{array}{l}\text { Sustainable agriculture \& } \\
\text { forestry }\end{array}$ & $\begin{array}{l}\text { Input- } \\
\text { agriculture \& } \\
\text { forestry }\end{array}$ & $\begin{array}{l}\text { GBC 2009; OECD 2009; BMBF 2010; EC 2012; formas } \\
\text { 2012; Karp et al. 2015; Pietzsch 2017; Wesseler and } \\
\text { Braun } 2017\end{array}$ \\
\hline $\begin{array}{l}\text { Climate \& environmental } \\
\text { protection }\end{array}$ & $\begin{array}{l}\text { Input-climate } \\
\& \\
\text { environment }\end{array}$ & $\begin{array}{l}\text { OECD 2009; EC 2012; McCormick and Kautto 2013; } \\
\text { Bugge et al. 2016; Hausknost et al. } 2017\end{array}$ \\
\hline Green biotechnology & $\begin{array}{l}\text { Processing- } \\
\text { green biotech. }\end{array}$ & $\begin{array}{l}\text { OECD 2009; BMBF 2010; McCormick and Kautto 2013; } \\
\text { Golembiewski et al. 2015; Karp et al. 2015; Lee 2016; } \\
\text { Wesseler and Braun 2017 }\end{array}$ \\
\hline Blue biotechnology & $\begin{array}{l}\text { Processing- } \\
\text { green biotech. }\end{array}$ & $\begin{array}{l}\text { EC 2012; McCormick and Kautto 2013; BMEL 2014; } \\
\text { Zinke et al. } 2016\end{array}$ \\
\hline
\end{tabular}


Table 6 (continued)

\begin{tabular}{|c|c|c|}
\hline Subject and objectives & Dimensions & Source \\
\hline Red biotechnology & $\begin{array}{l}\text { Processing-red } \\
\text { biotech. }\end{array}$ & $\begin{array}{l}\text { OECD 2009; BMBF 2010; The White House 2012; } \\
\text { Petersen and Krisjansen 2015; Bugge et al. 2016; GBC } \\
\text { 2016; Wesseler and Braun } 2017\end{array}$ \\
\hline White biotechnology & $\begin{array}{l}\text { Processing- } \\
\text { white biotech. }\end{array}$ & $\begin{array}{l}\text { Aguilar et al. 2009; OECD 2009; BMBF 2010; EC 2012; } \\
\text { Sillanpää and Ncibi } 2017\end{array}$ \\
\hline $\begin{array}{l}\text { Food \& feed } \\
\text { production/refinement }\end{array}$ & $\begin{array}{l}\text { Output-food \& } \\
\text { feed }\end{array}$ & $\begin{array}{l}\text { GBC 2009; BMBF 2010; EC 2012; BMEL 2014; Viaggi } \\
\text { 2016; Sillanpää and Ncibi } 2017\end{array}$ \\
\hline $\begin{array}{l}\text { Chemicals, organic } \\
\text { components }\end{array}$ & $\begin{array}{l}\text { Output- } \\
\text { products \& } \\
\text { materials }\end{array}$ & $\begin{array}{l}\text { GBC 2009; BMBF 2010; EC 2012; Staffas et al. 2013; } \\
\text { Golembiewski et al. 2015; Karp et al. 2015; Sillanpää } \\
\text { and Ncibi 2017; Wesseler and Braun } 2017\end{array}$ \\
\hline Pulp and paper industries & $\begin{array}{l}\text { Output- } \\
\text { products \& } \\
\text { materials }\end{array}$ & $\begin{array}{l}\text { BMBF 2010; EC 2012; Pietzsch 2017; Sillanpää and } \\
\text { Ncibi 2017; Wesseler and Braun 2017; Hermans 2018; } \\
\text { Purkus et al. } 2018\end{array}$ \\
\hline $\begin{array}{l}\text { Energy production from } \\
\text { biomass }\end{array}$ & $\begin{array}{l}\text { Output-energy } \\
\text { \& fuels }\end{array}$ & $\begin{array}{l}\text { BMBF 2010; EC 2012; McCormick and Kautto 2013; } \\
\text { Sillanpää and Ncibi } 2017\end{array}$ \\
\hline $\begin{array}{l}\text { Coherent policies \& their } \\
\text { evaluation }\end{array}$ & $\begin{array}{l}\text { Socio-economic } \\
\text { framework }\end{array}$ & $\begin{array}{l}\text { BMBF 2010; EC 2012; McCormick and Kautto 2013; } \\
\text { BMEL 2014; Dietz et al. 2018; Philp } 2018\end{array}$ \\
\hline $\begin{array}{l}\text { Communication with \& } \\
\text { sensitisation of the public }\end{array}$ & $\begin{array}{l}\text { Socio-economic } \\
\text { framework }\end{array}$ & $\begin{array}{l}\text { BMBF 2010; EC 2012; BMEL 2014; Bugge et al. 2016; } \\
\quad \text { Pietzsch } 2017\end{array}$ \\
\hline $\begin{array}{l}\text { Bio-related education \& } \\
\text { qualification }\end{array}$ & $\begin{array}{l}\text { Socio-economic } \\
\text { framework }\end{array}$ & $\begin{array}{l}\text { EC 2012; formas 2012; McCormick and Kautto 2013; } \\
\text { BMEL 2014; Zinke et al. 2016; Sillanpää and Ncibi } \\
2017\end{array}$ \\
\hline $\begin{array}{l}\text { Venture capital, financing of } \\
\text { bioeconomy firms }\end{array}$ & $\begin{array}{l}\text { Socio-economic } \\
\text { framework }\end{array}$ & $\begin{array}{l}\text { EC 2012; Zilberman et al. 2013; BMEL 2014; GBC } \\
\text { 2016; Viaggi } 2016\end{array}$ \\
\hline $\begin{array}{l}\text { Networking, partnership, } \\
\text { knowledge-diffusion }\end{array}$ & $\begin{array}{l}\text { Socio-economic } \\
\text { framework }\end{array}$ & $\begin{array}{l}\text { Albert 2007; OECD 2009; BMBF 2010; McCormick and } \\
\text { Kautto 2013; Zilberman et al. 2013; BMEL 2014; } \\
\text { McDonagh 2014; Bugge et al. } 2016\end{array}$ \\
\hline $\begin{array}{l}\text { Ethics (GMO, animal welfare } \\
\text { etc.) }\end{array}$ & $\begin{array}{l}\text { Socio-economic } \\
\text { framework }\end{array}$ & $\begin{array}{l}\text { Paula and Birrer 2006; Bennett 2007; McCormick and } \\
\text { Kautto 2013; Bugge et al. 2016; Sillanpää and Ncibi } \\
2017\end{array}$ \\
\hline Competitive land use & Cross-cutting & Pietzsch 2017 \\
\hline $\begin{array}{l}\text { Working in cascade, } \\
\text { minimising waste, circular } \\
\text { economy }\end{array}$ & Cross-cutting & Lee 2016; Pietzsch 2017 \\
\hline
\end{tabular}




\title{
Appendix 2
}

Conflict of interest The authors declare no competing interests.

Table 7 Keywords and counts for text-mining

\begin{abstract}
Key words for text-mining-counting as 1
actinomy, aeruginosa, agrar, agri, agro, aktinomycet, alga, alge, algi, alkaloid, <allel>, <allele>, allelop, amino, anbau, antig, antikörp, apfelanbau, apheres, apoptos, aptam, arabidopsis, archae, array, assay, astacus, autotroph, baccatin, bacillus, bact, bakt, barley, basidiomycet, baum, bäum, beet, bio, blut, bodenfruchtbarkeit, brassica, breed, canola, carotin, cellulose, cereal, cerevisia, chitin, chitosan, chlorophyll, chloroplast, chromosom, clib, coli, coryne, cuphea, cyto, denitrifikation, derivat, diversitat, dna, drosophila, edelkreb, eiwei, elisa, embryo, endog, enzym, epilyz, epitop, erblich, ernte, erreger, escherichia, esteras, eukary, eutropha, farming, fauna, feedstock, ferkel, ferment, fett, fettsaeur, fettsäur, flachsfaser, flavonoid, fleisch, flora, food, forst, freiland, frucht, frücht, fruecht, fungeos, fungus, fusarium, futter, gartenbau, geflügel, gehirn, <gen $>,<$ gene $>$, $<$ genen $>$, gerst, getraenke, getränke, getreid, gewachs, gewächs, gewachshaus, gewaechs, glioblastom, glucos, glutamat, glutamicum, glyc, glyk, golgi, grain, haploid, harnstoff, hefe, hepatozyten, heterotroph, hoelz, holz, hölz, homolog, homozygot, honigbi, hormon, hortinlea, <hsp, human, hydroformyl, hydrolys, inhibitor, insekt, interferon, inulin, ipas, kairomon, kartoffel, kartoffelkreb, kaskad, kautschuk, keim, kiefer, klonal, kohlenhy, koksaghyz, kollag, kolorektal, korn, kultivierung, landrass, landwirtschaft, leben, leber, legehenn, leguminos, lektin, liganden, lignin, ligno, lipas, lipid, lockstoff, lymph, lysin, lyso, maeus, mais, malign, marin, markergestützt, maus, mäus, meliloti, mesenchymal, metabol, methylier, mikroalg, mikroben, mikrobie, milch, milchkuh, miscanthus, mistel, mitochond, mizell, monozyt, morbus, morphism, mrna, mutant, mutation, mykorr, nachwachs, naehr, nahr, nähr, napus, natuer, natür, nematod, neuron, nukleas, nuklease, nuklein, nukleinsäure, nukleinseaure, <oel>, <oil>, okolog, okosys, <öl>, oled, oligom, oligonukleotid, omega, omics, organ, osmose, palmoel, palmöl, papier, pappel, pathog, pcr, pektin, peptid, pferd, pflanz, phaeno, phano, phäno, phanomics, phenom, pheromon, photosynth, phytopathog, pilz, plant, plantag, plasmid, pluripotent, polymerase, polyoma, pradikativ, prädikativ, praedikativ, praparat, prokaryot, proteas, protein, proteom, protoplast, pseudomonas, qtl, raps, rekomb, resistenzg, retikulum, rezeptor, rhizobium, rhizosph, ribosom, $<$ rna $>$, $<$ rnas $>$, $<$ rns $>$, rogg, saat, sacch, samen, schädling, schaedling, schwein, sequenzanalys, serum, sinapin, sirna, snp, solanum, somat, sonnenblum, staphylococcus, staphylokinas, starkevarietat, stärkevarietät, steroid, stofflich, stoffumwandl, stoffwechsel, streptomycet, stroh, subtilis, tannen, taraxacum, tarulin, thaliana, thuringiensis, tierisch, tilling, tissu, transgen, transkriptom, tropi, vakzin, vegeta, vitamin, vitro, vivo, vulgaris, wald, wein, weißstängel, weissstängel, weiz, wheat, wood, wuchsstoff, xylos, zebra, zellkultur, zerocarbfp, zoonos, zucht, zücht, zucker, zuecht, zwitter

Ambigious phrases — counting as 0.5
\end{abstract}

boden, böden, boeden, cell, erzeug, gen, kultur, laendlich, landlich, ländlich, leben, life, nachhalt, natur, oeko, öko, ressourc, rohstoff, umwelt, wirkstoff, zell

\section{Excluded phrases}

anorgan, antibakt, antibio, antimikrob, biografi, biographi, biometrie, biometrisch, biomimetik, biomimetisch, bionic, bionik, bionisch, implant, lagerstätt, oberkiefer, organisa, organiza, transplant, unterkiefer, vorgang

The symbol ' $<$ ' means that a phrase is only detected when no other letter or symbol is in front of the key word; same applies to ' $>$ ' for the ending of a key word; e.g. $<$ gen $>$ is only counted as one if it stands alone and thus means 'gene'; that leads to a search where words such as 'genug' (enough) are not recognised as a key word 


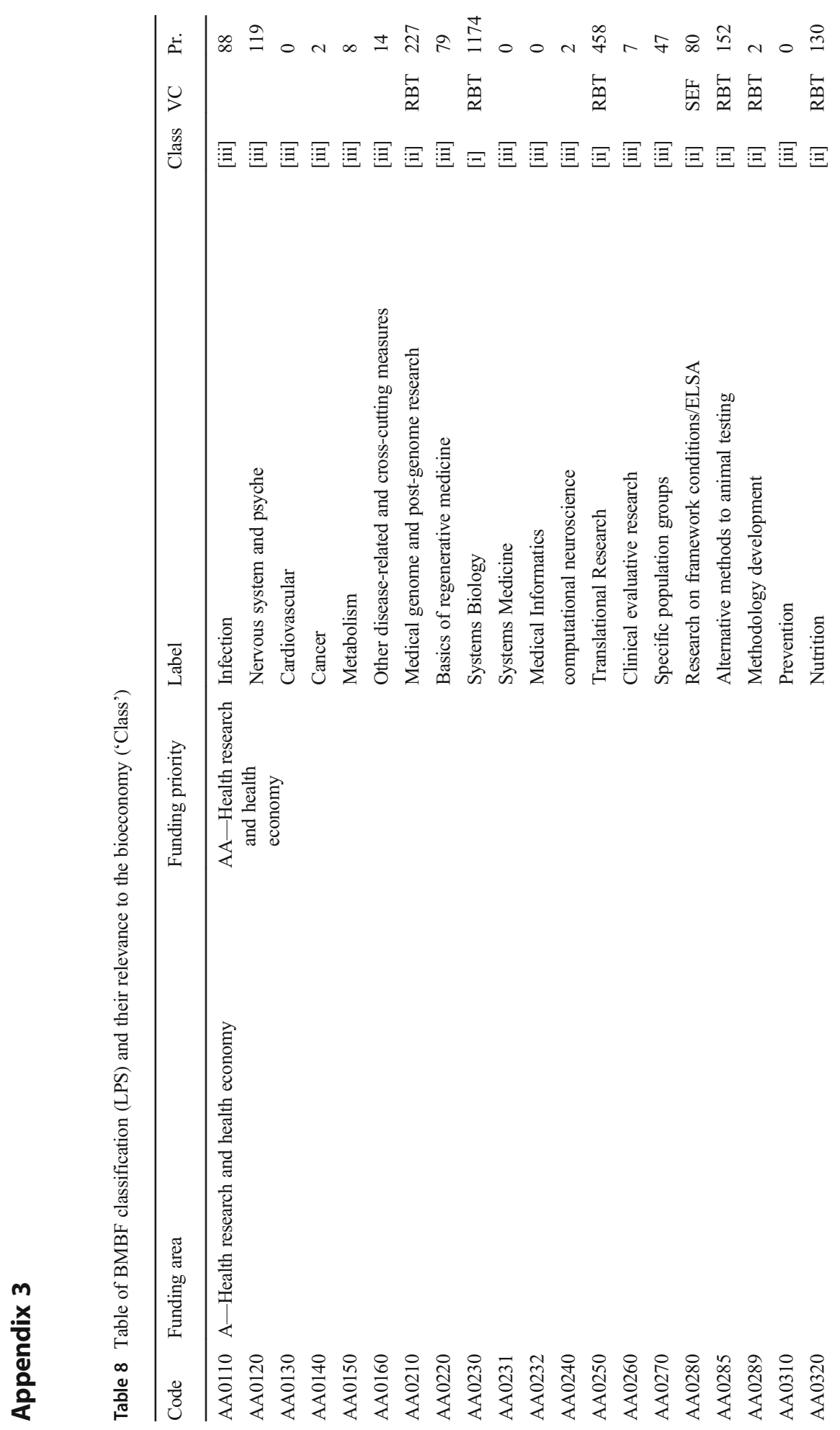




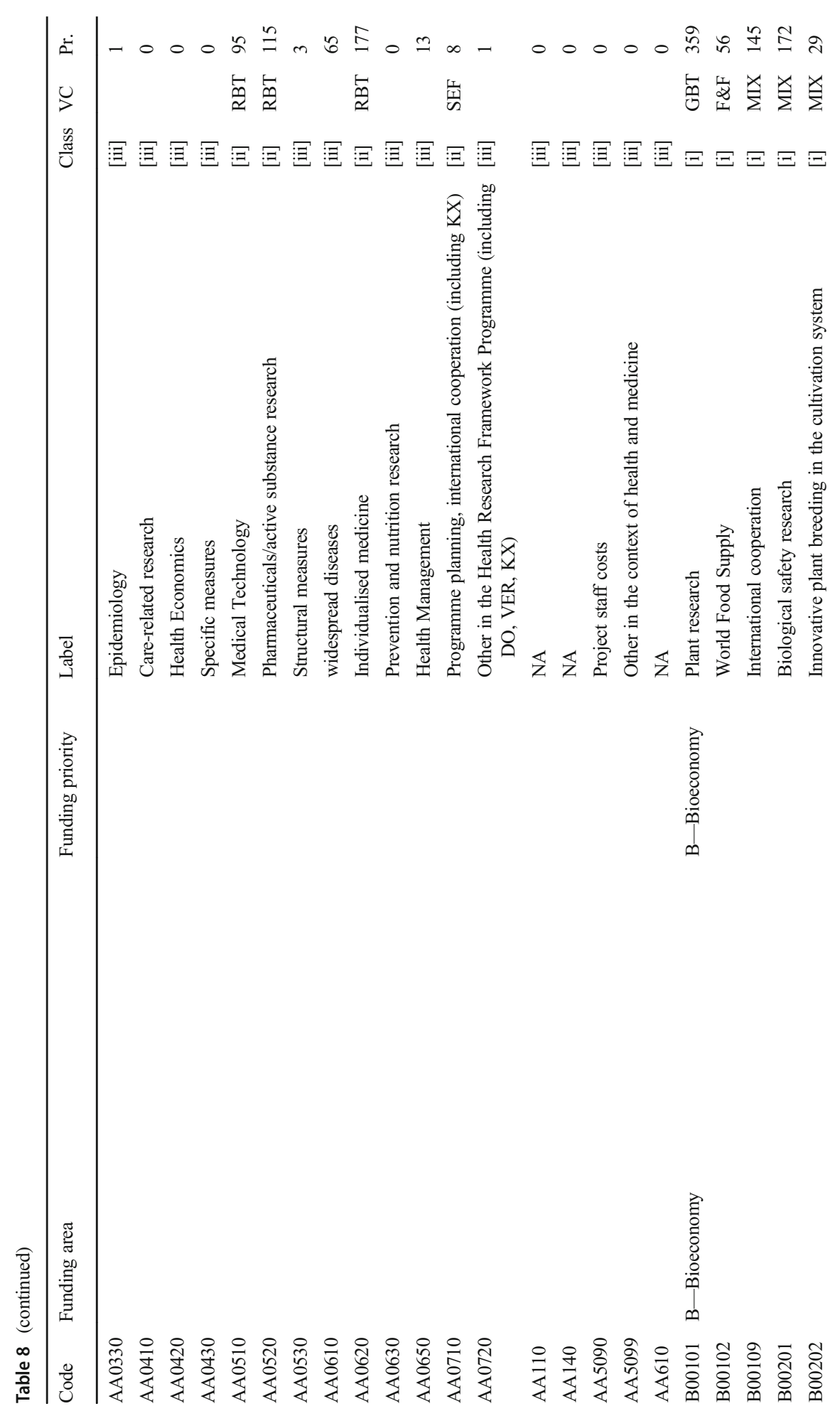




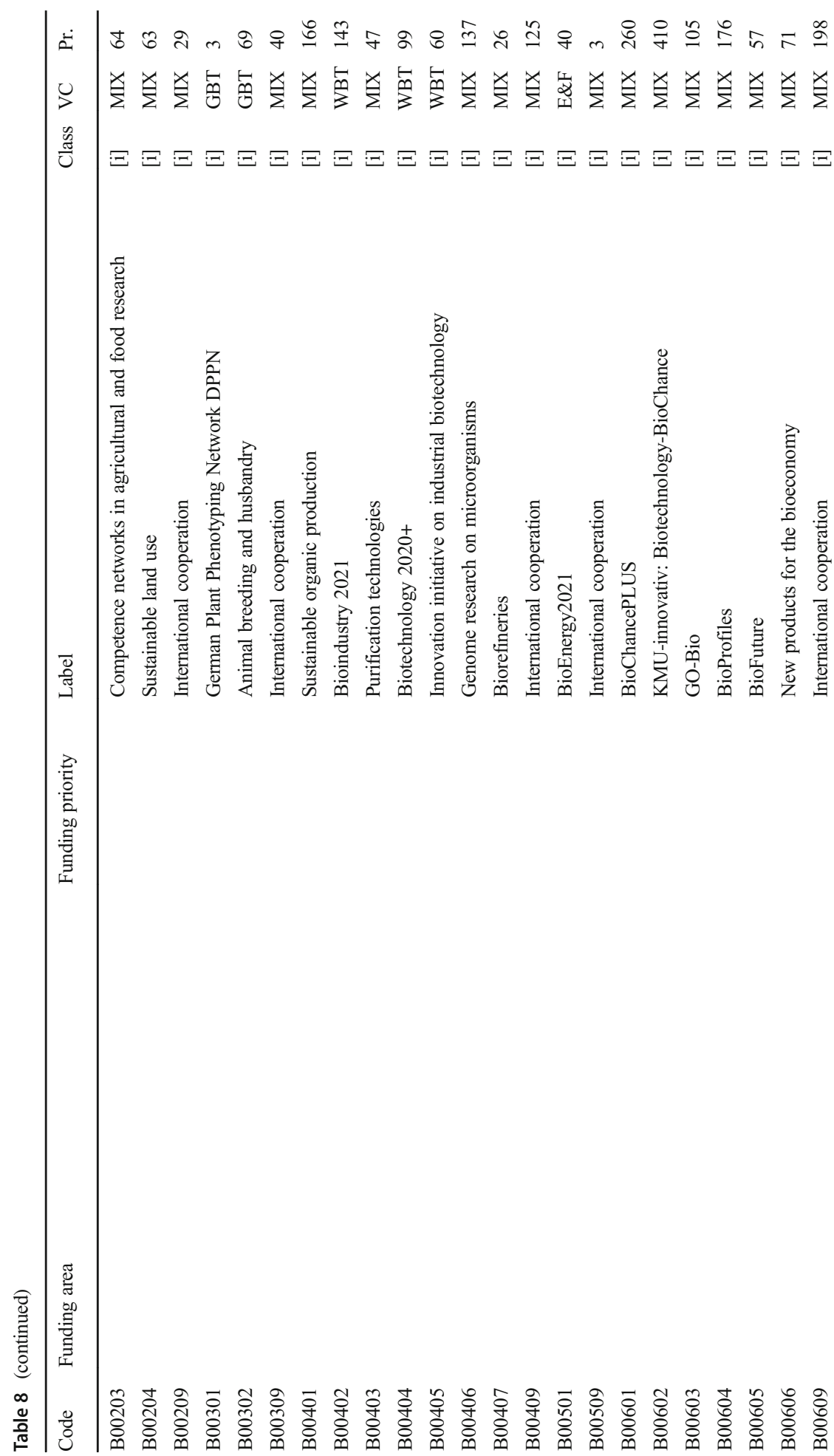




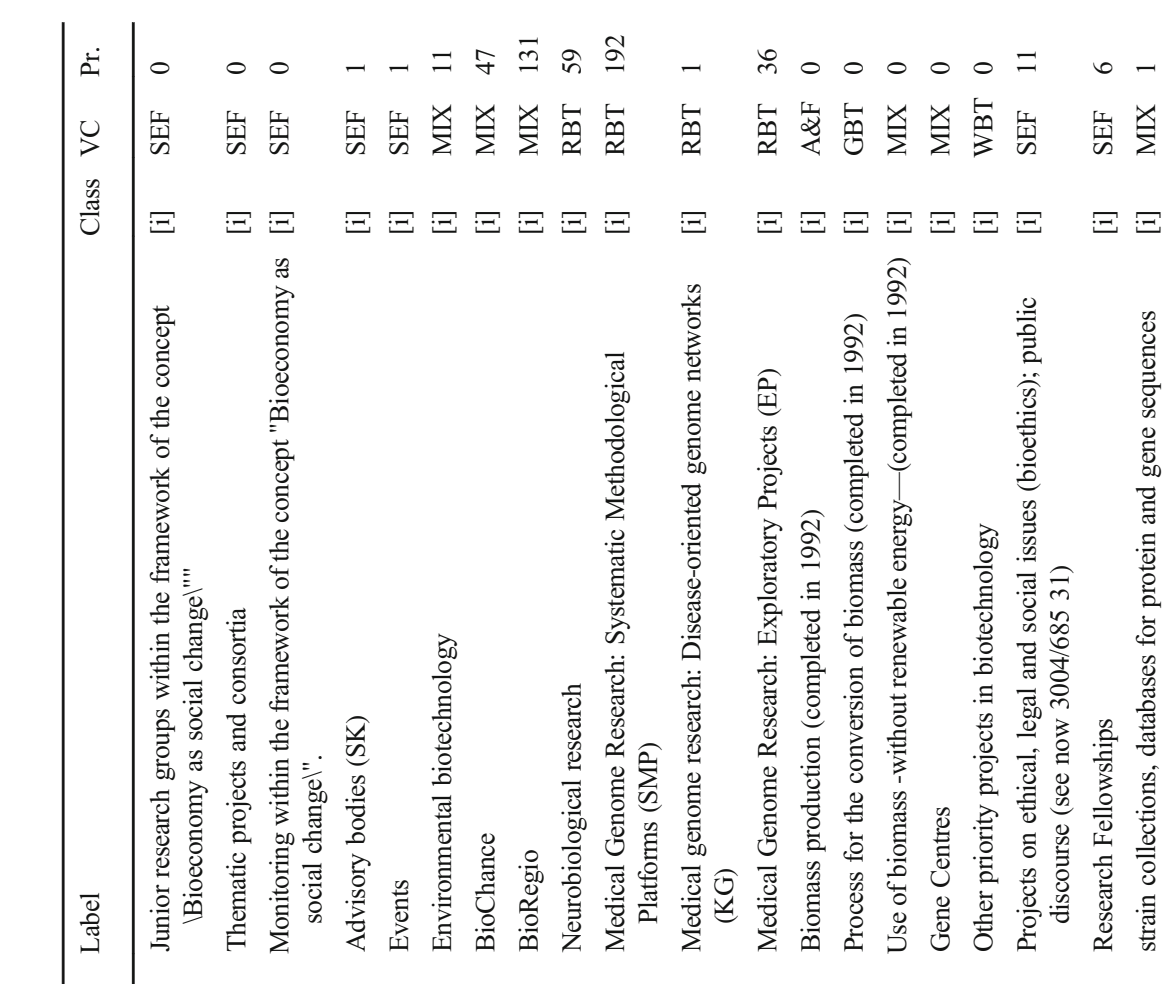

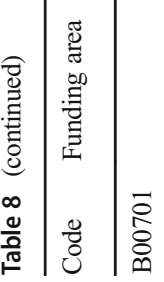




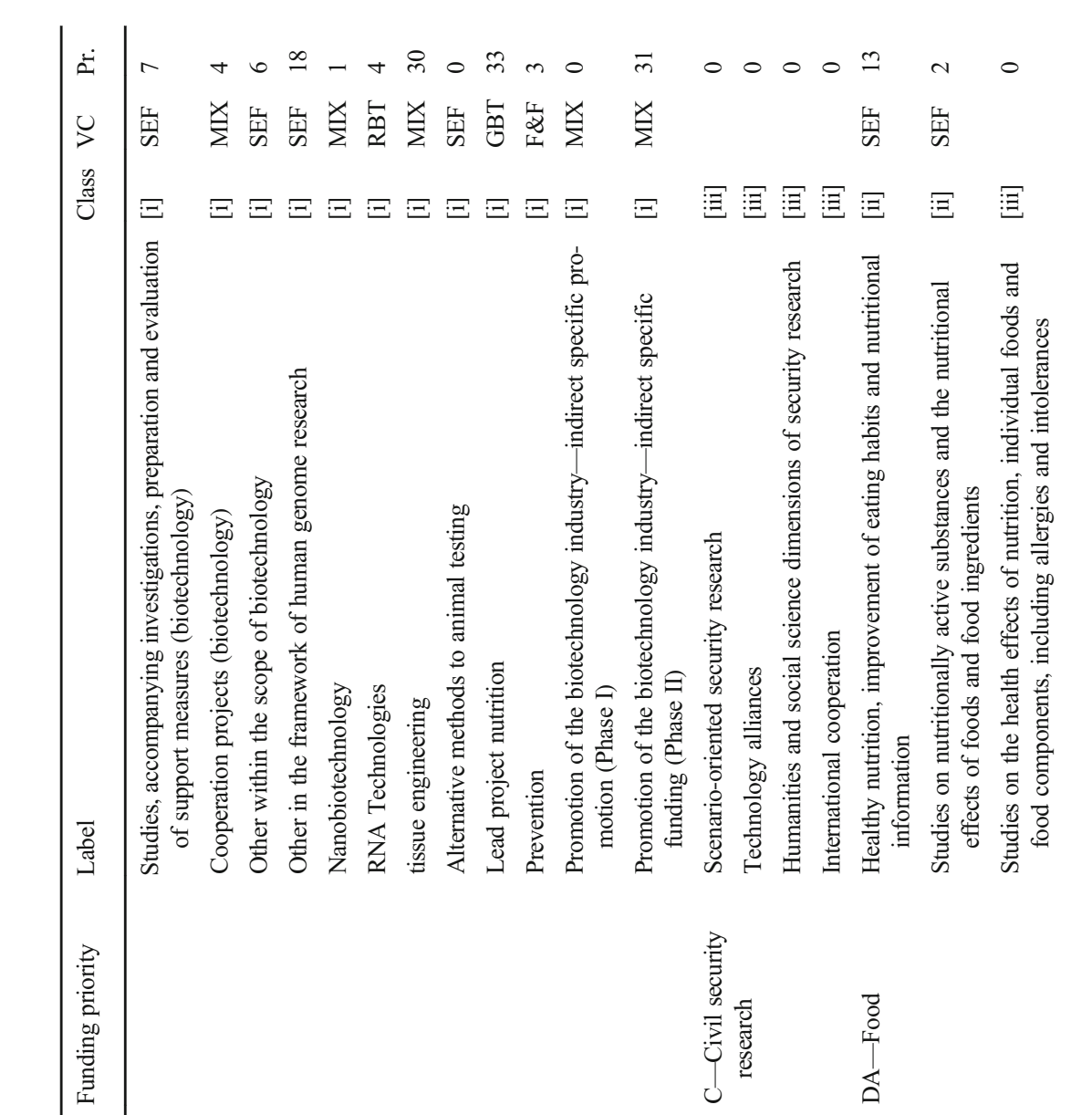




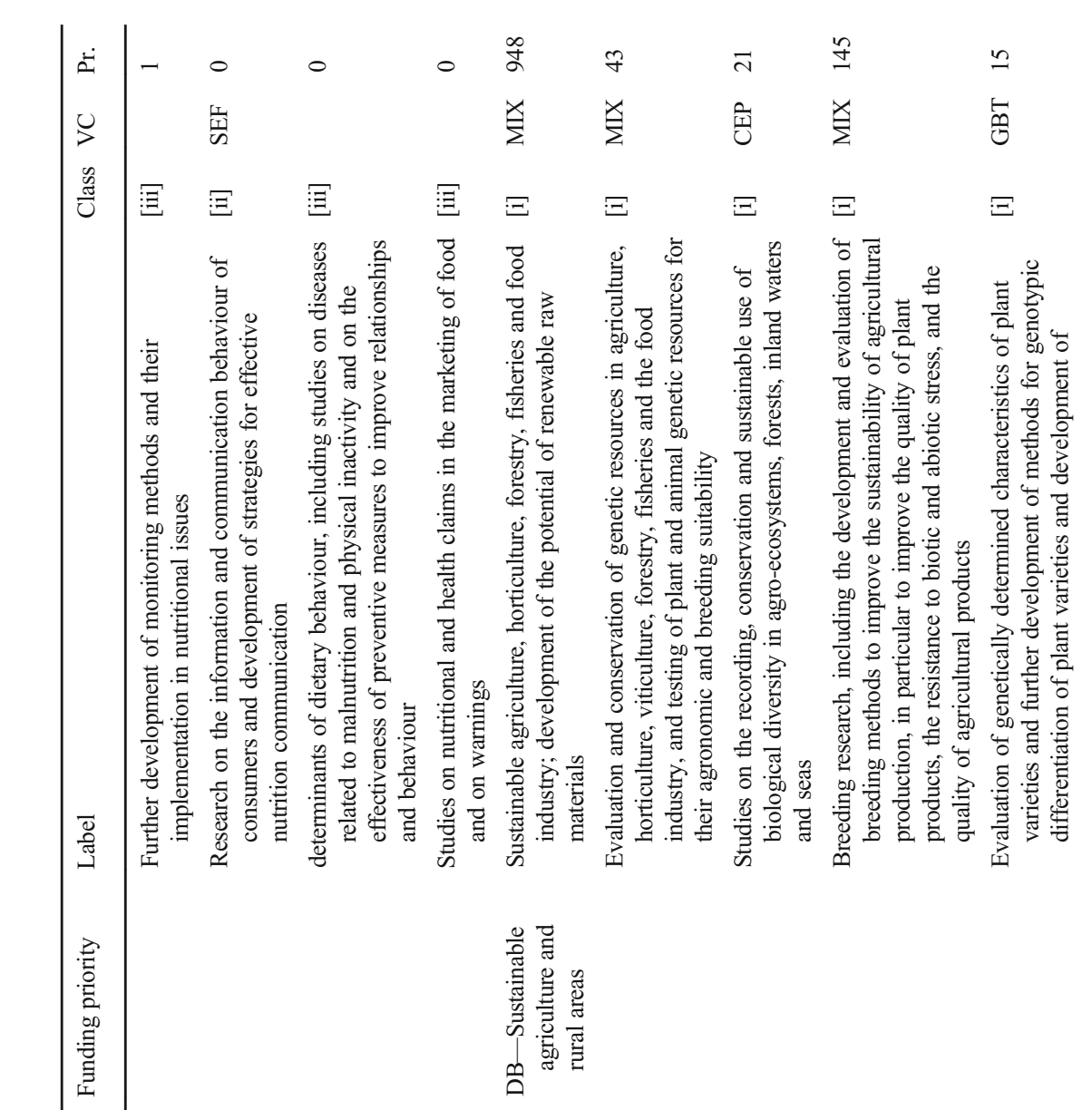




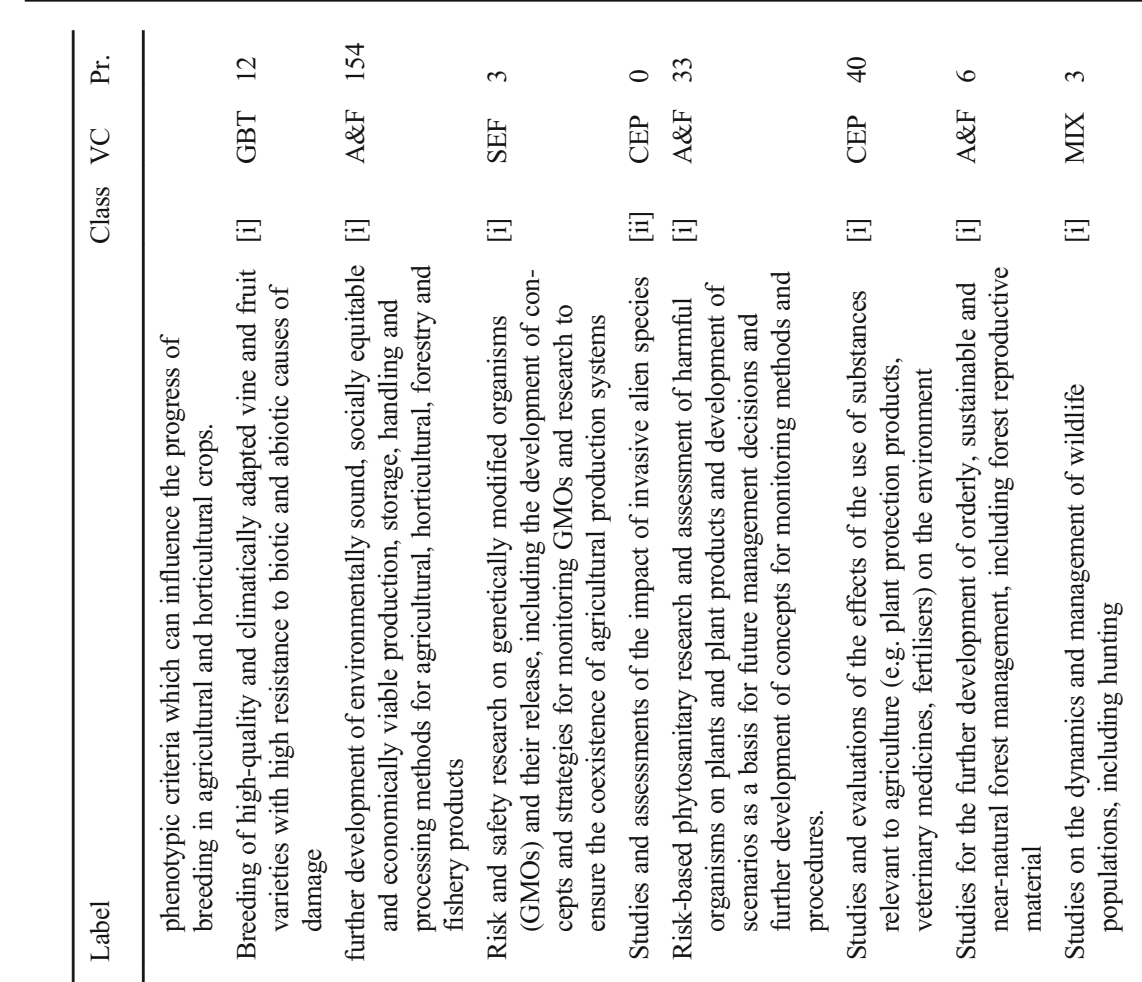

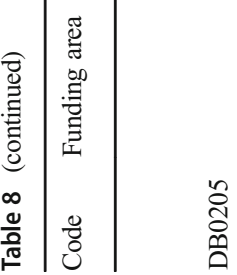

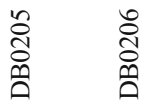

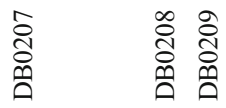

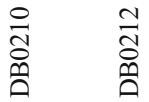

空 


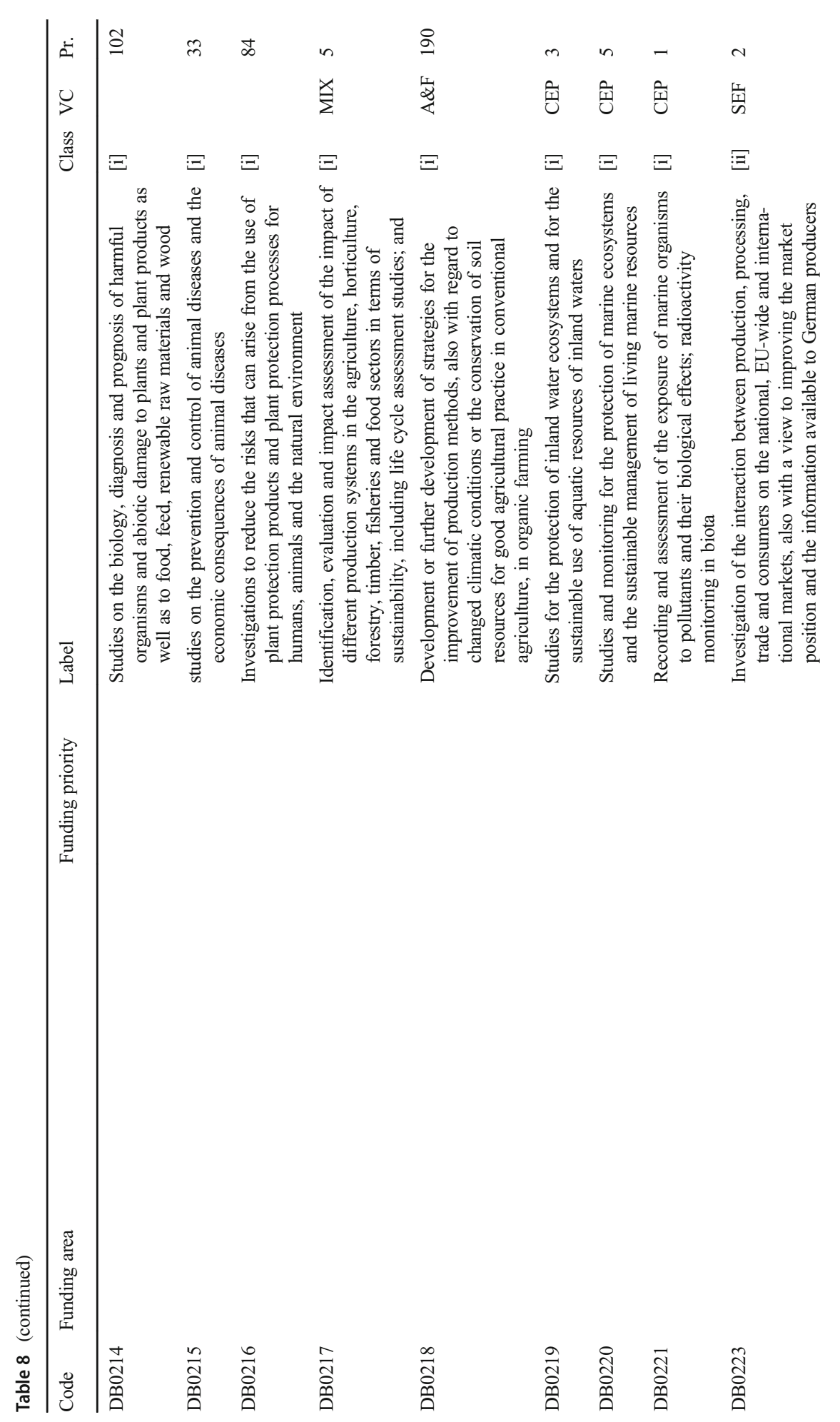




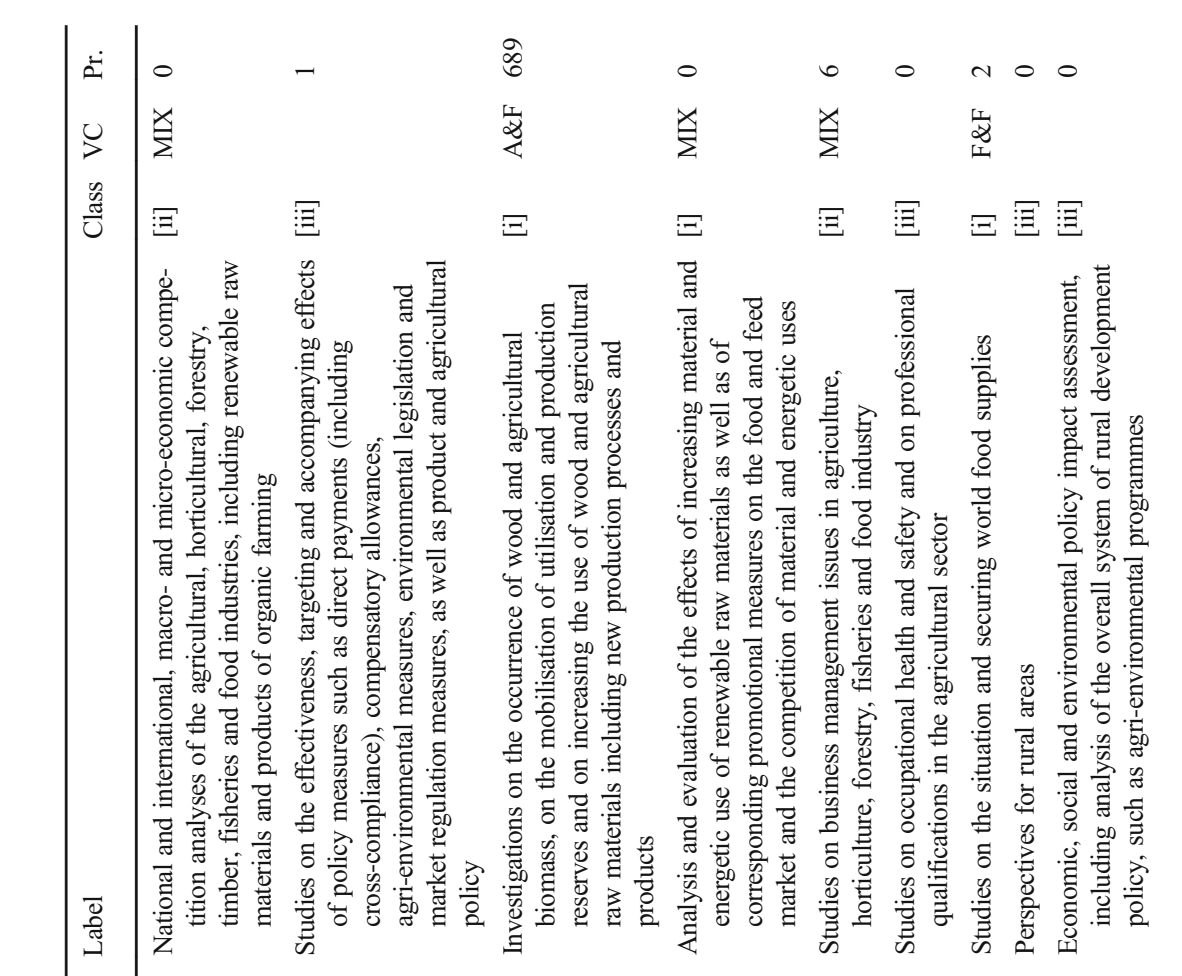




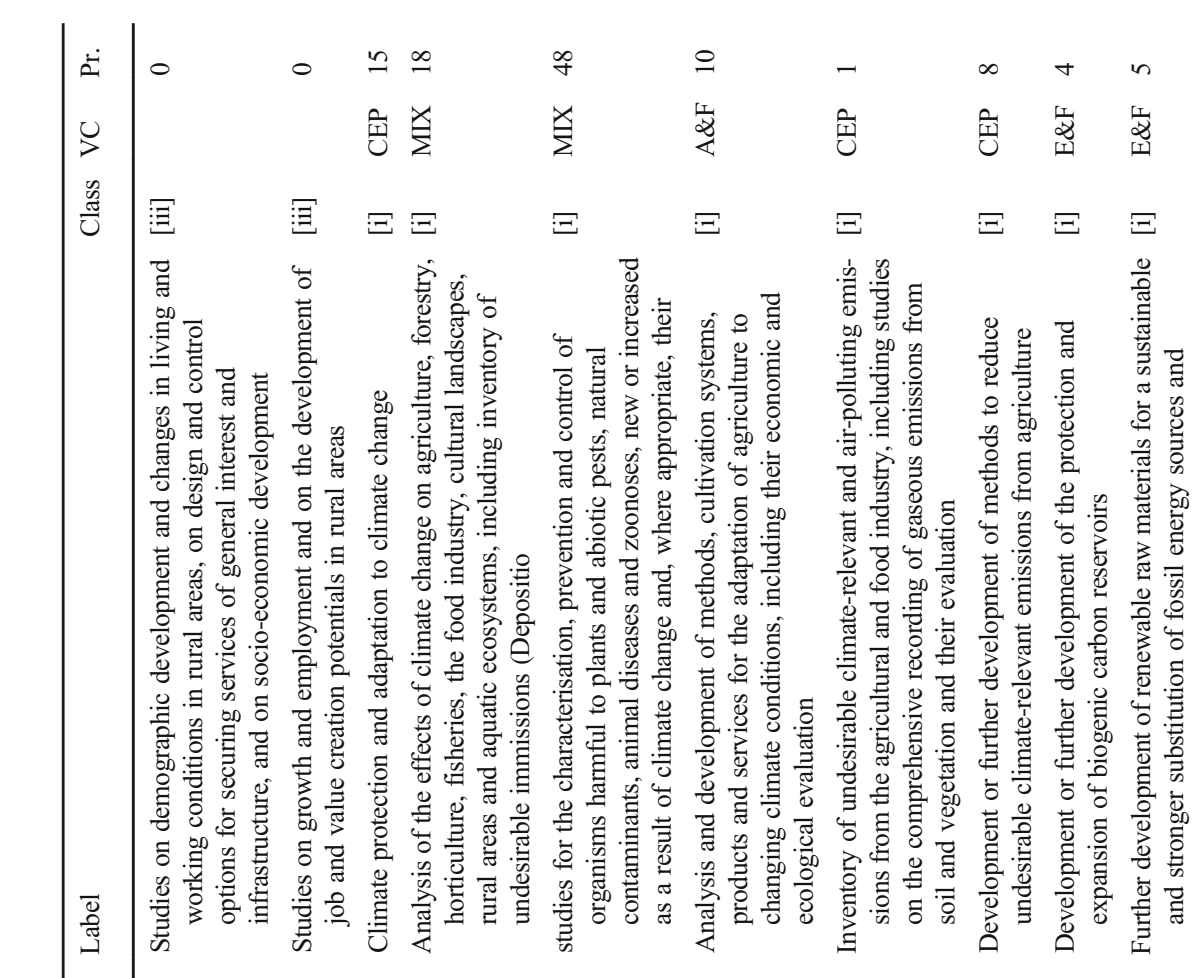

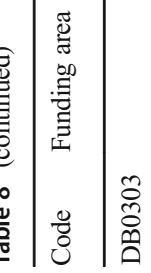

$\begin{array}{lll}\text { t } & 8 & 0 \\ 0 & + & 0 \\ 0 & 0 & 0 \\ 0 & 0 & 0\end{array}$

ô
+o
กิ

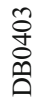

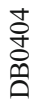

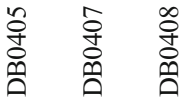




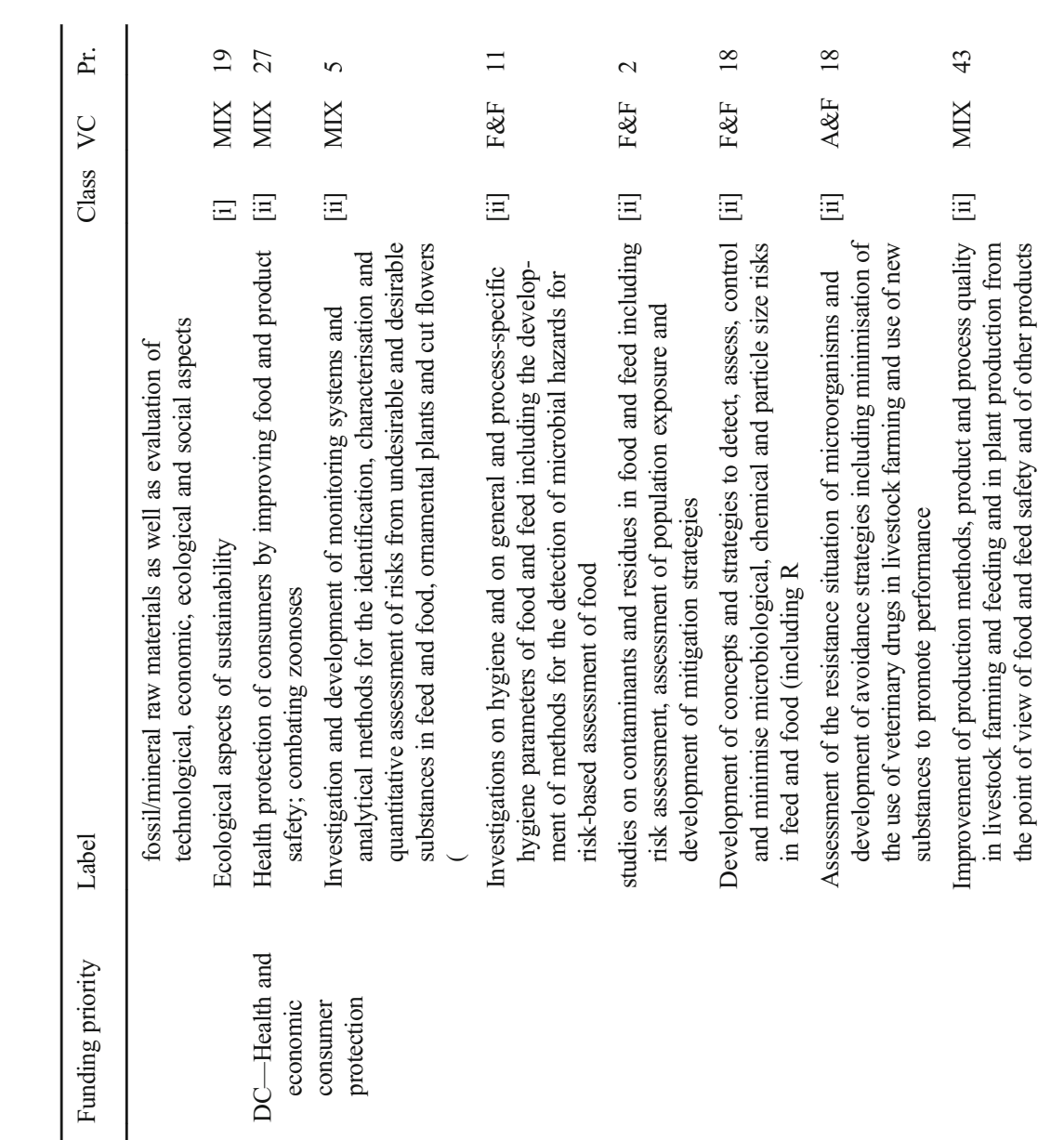

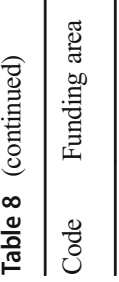

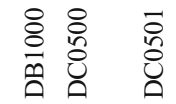

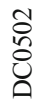

$\begin{array}{ll}0 & + \\ 0 & 8 \\ 0 & 8 \\ 0 & 0\end{array}$

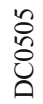

8: 


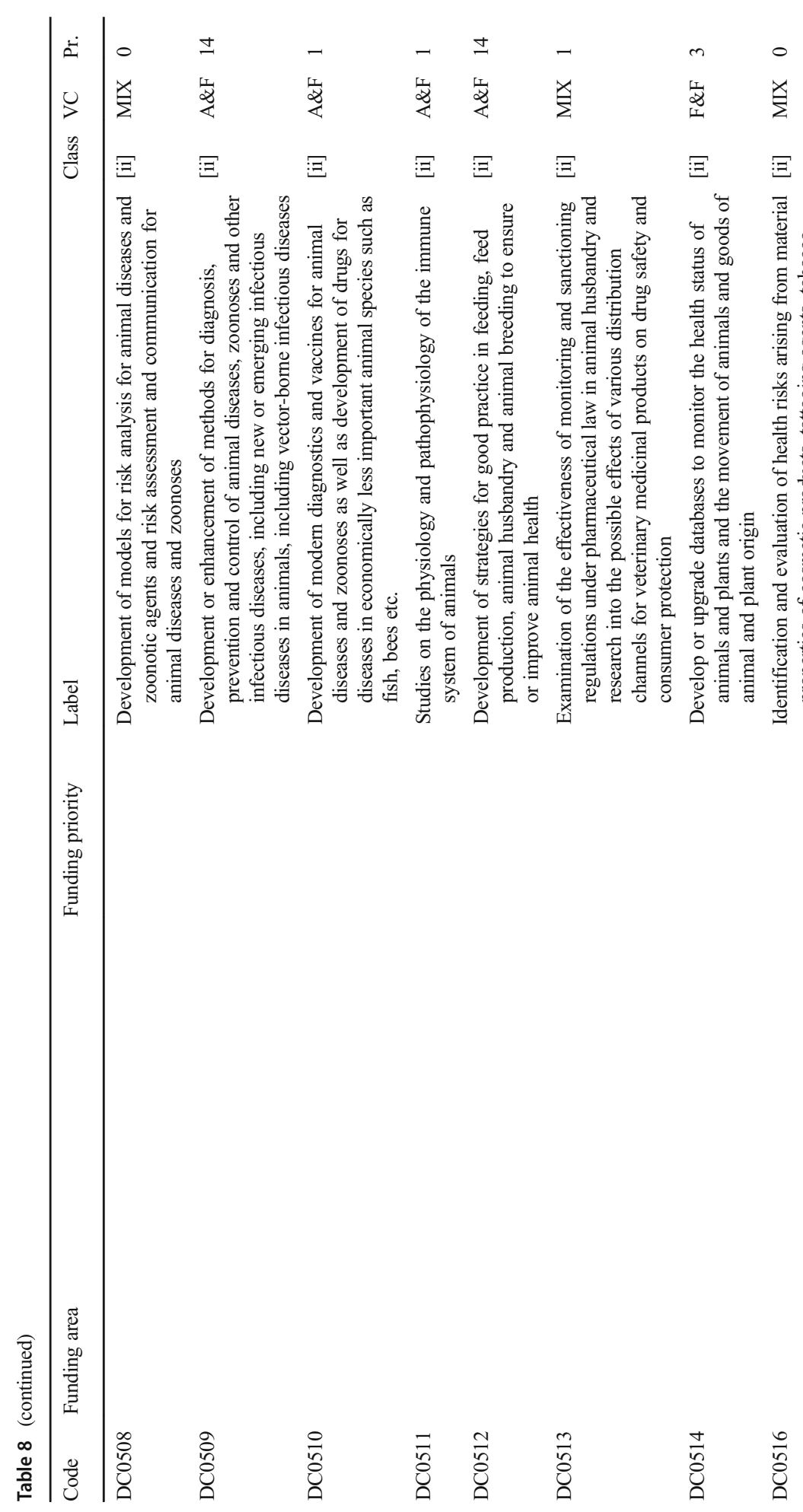




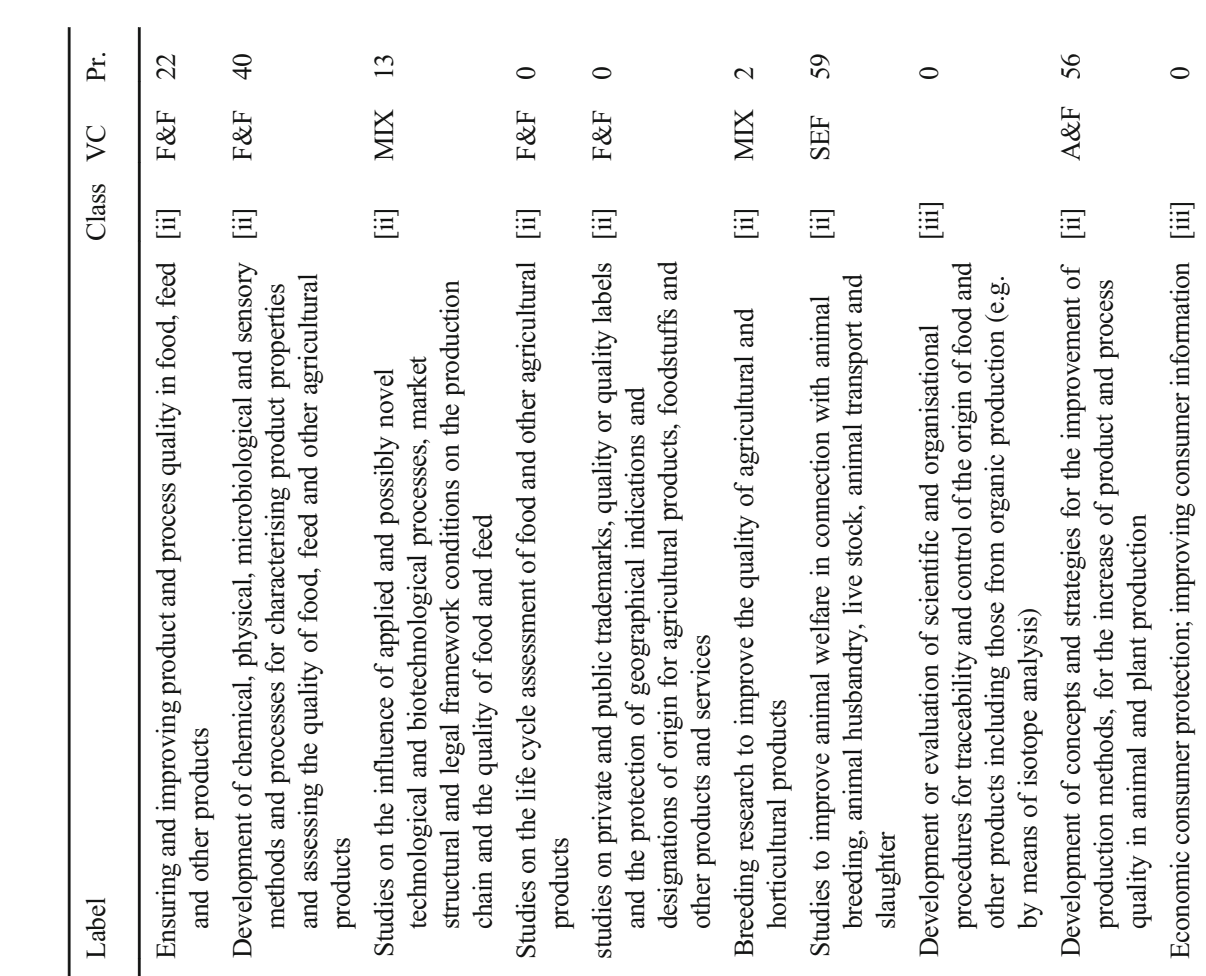




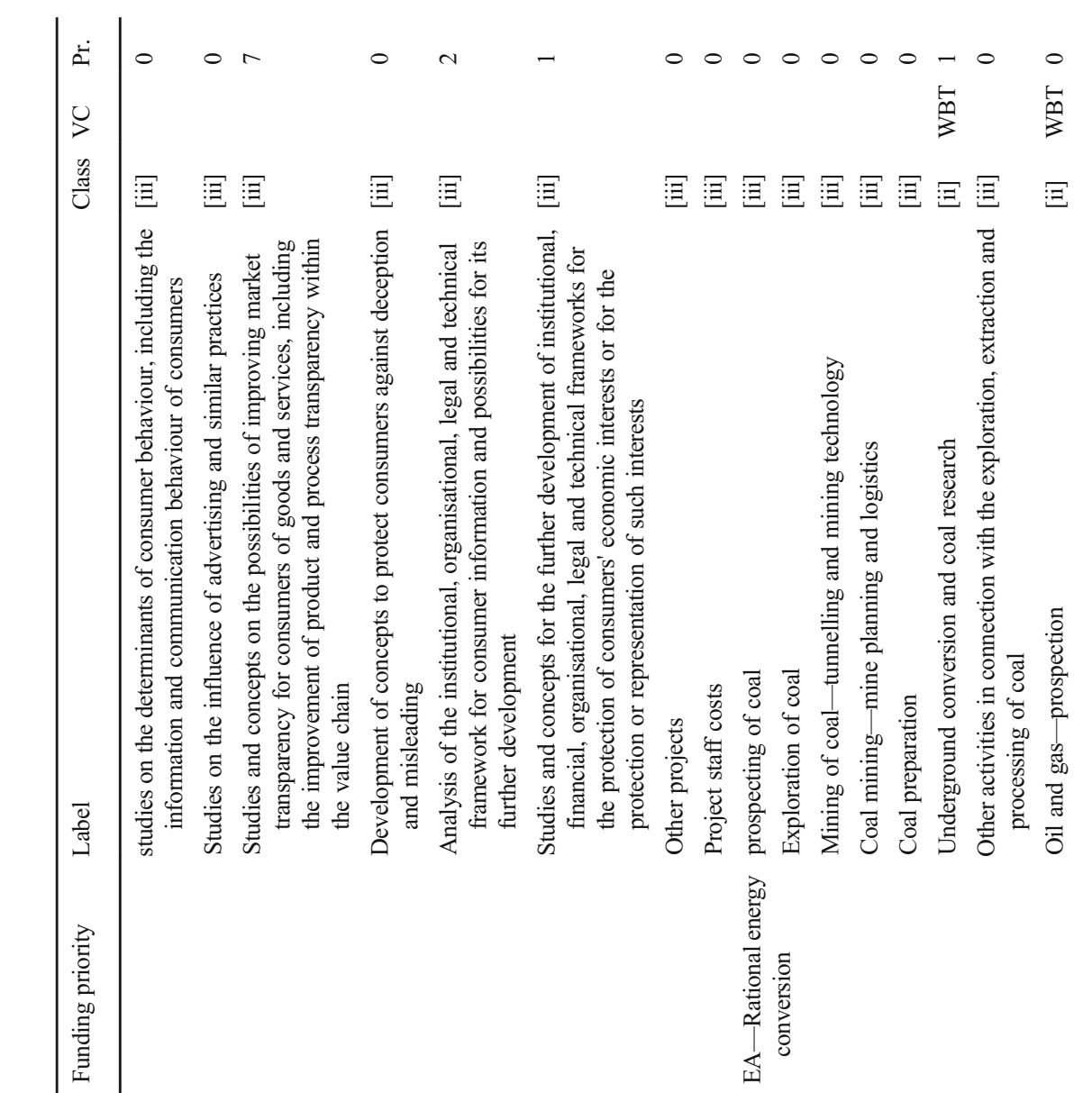

$\frac{\mathscr{y}}{60}$
$\frac{0}{0}$
$\frac{0}{0}$

क्.

:

苞

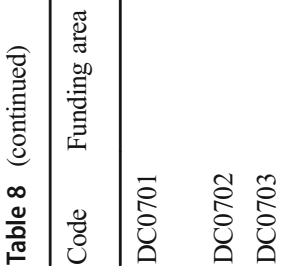

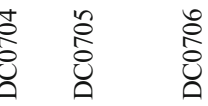

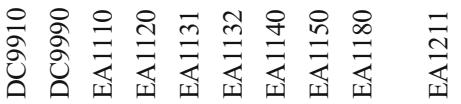




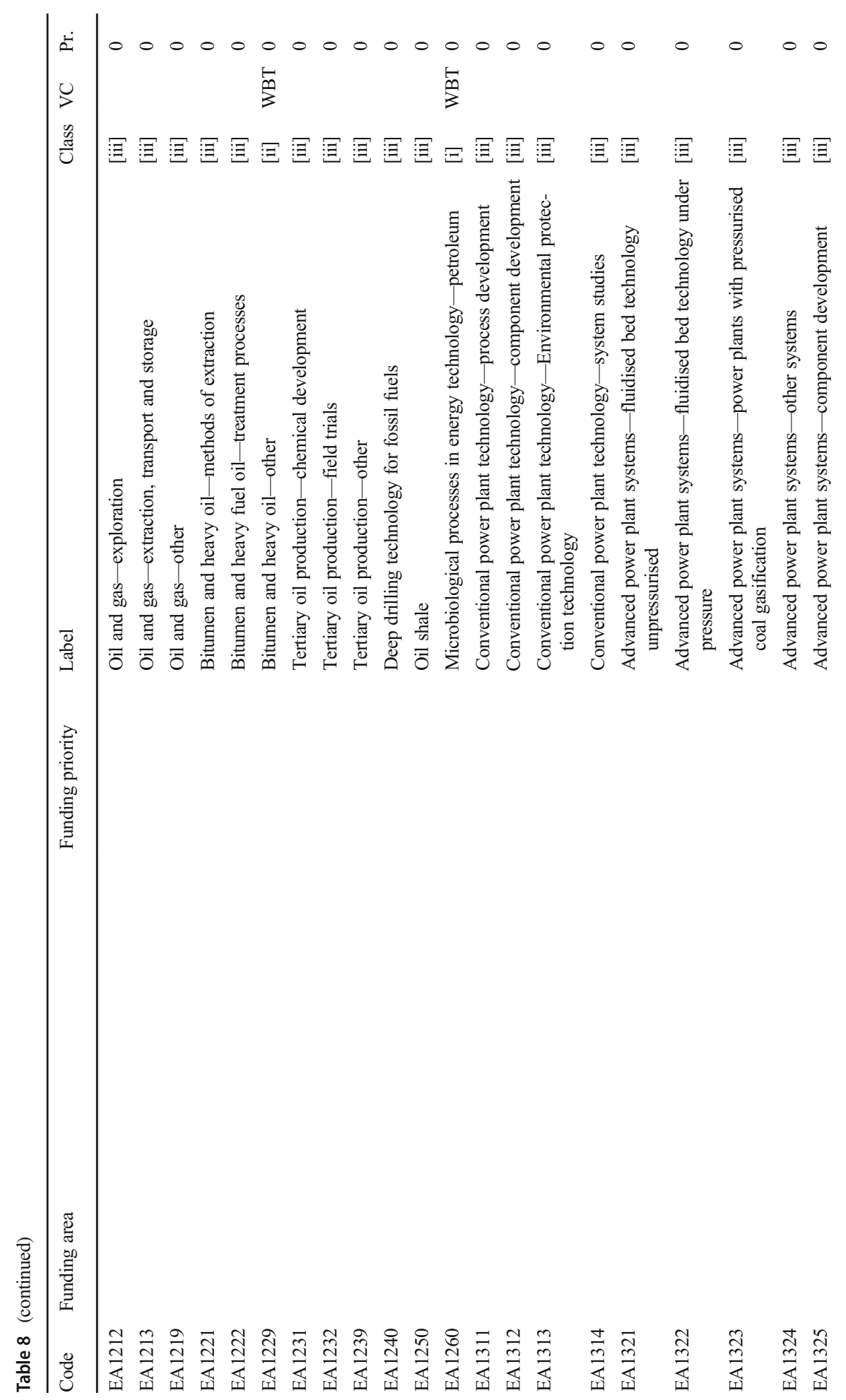




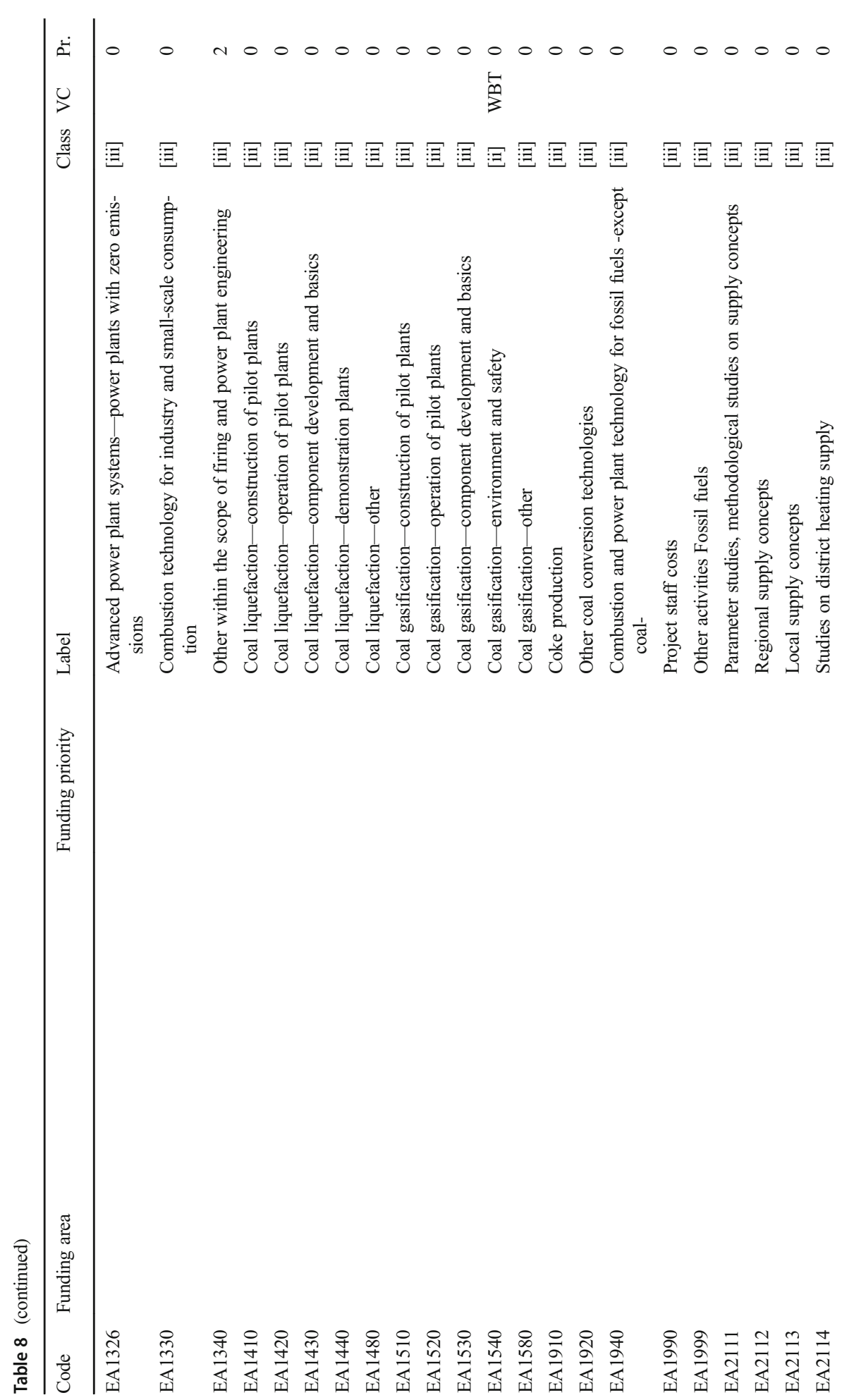




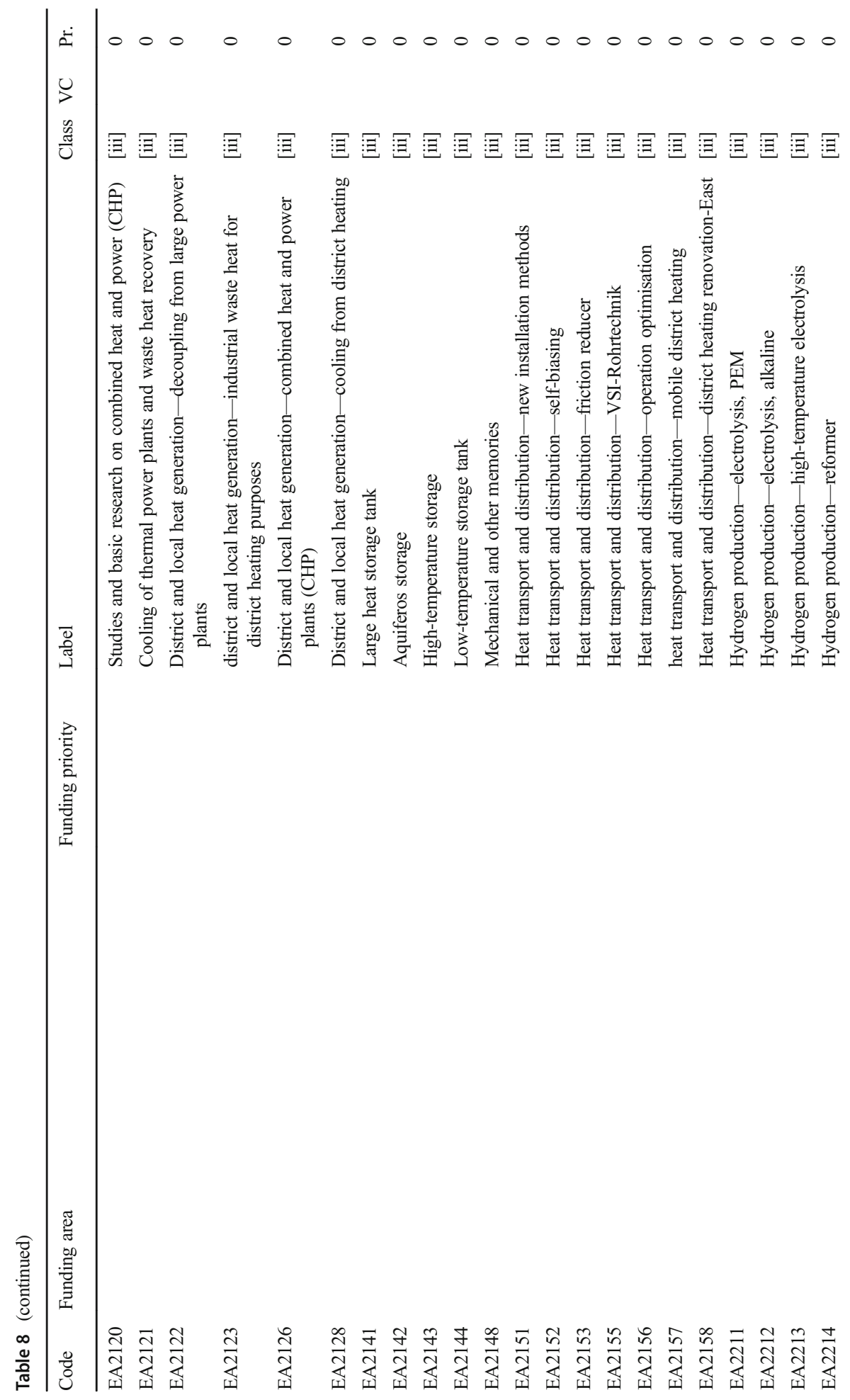




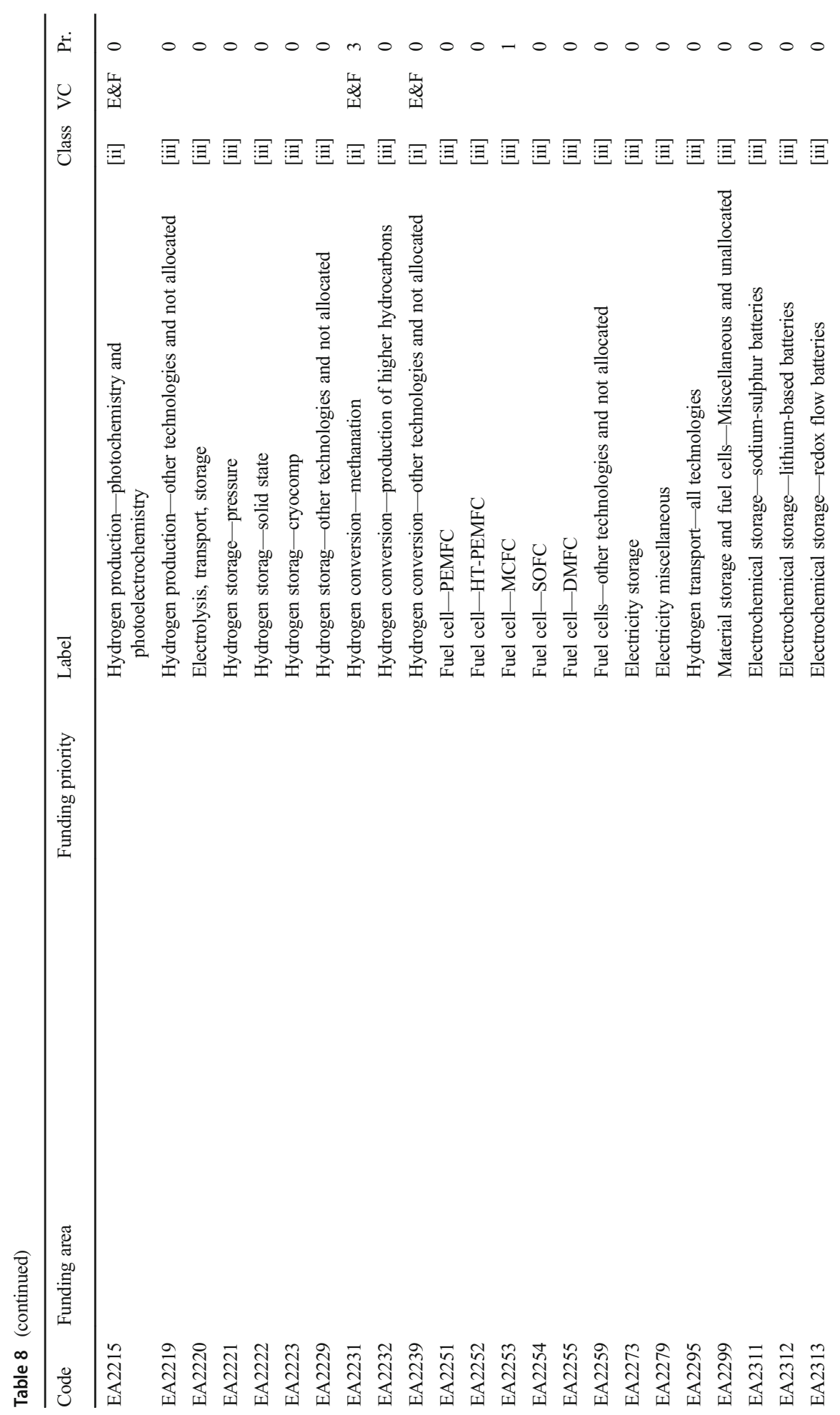




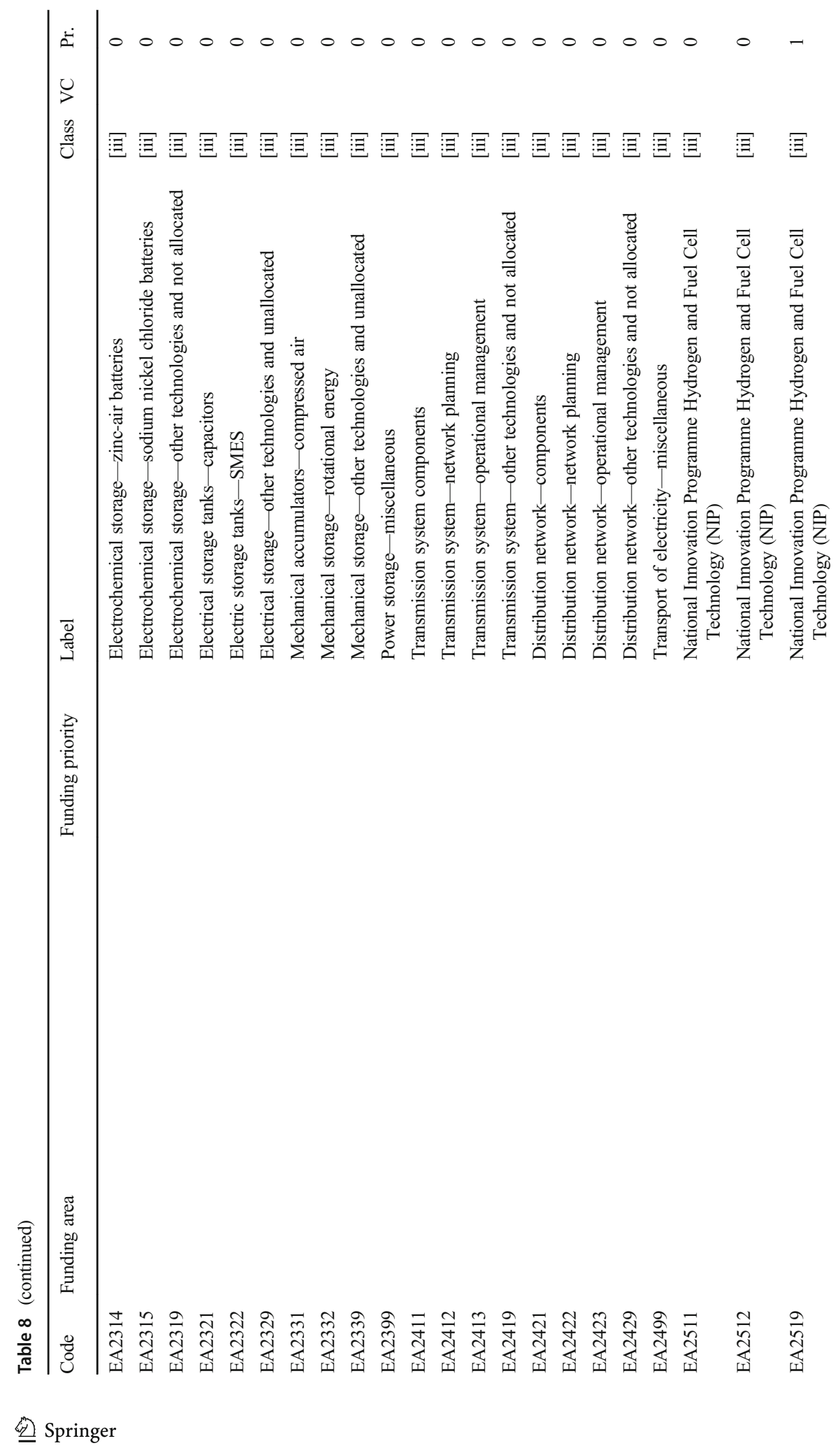




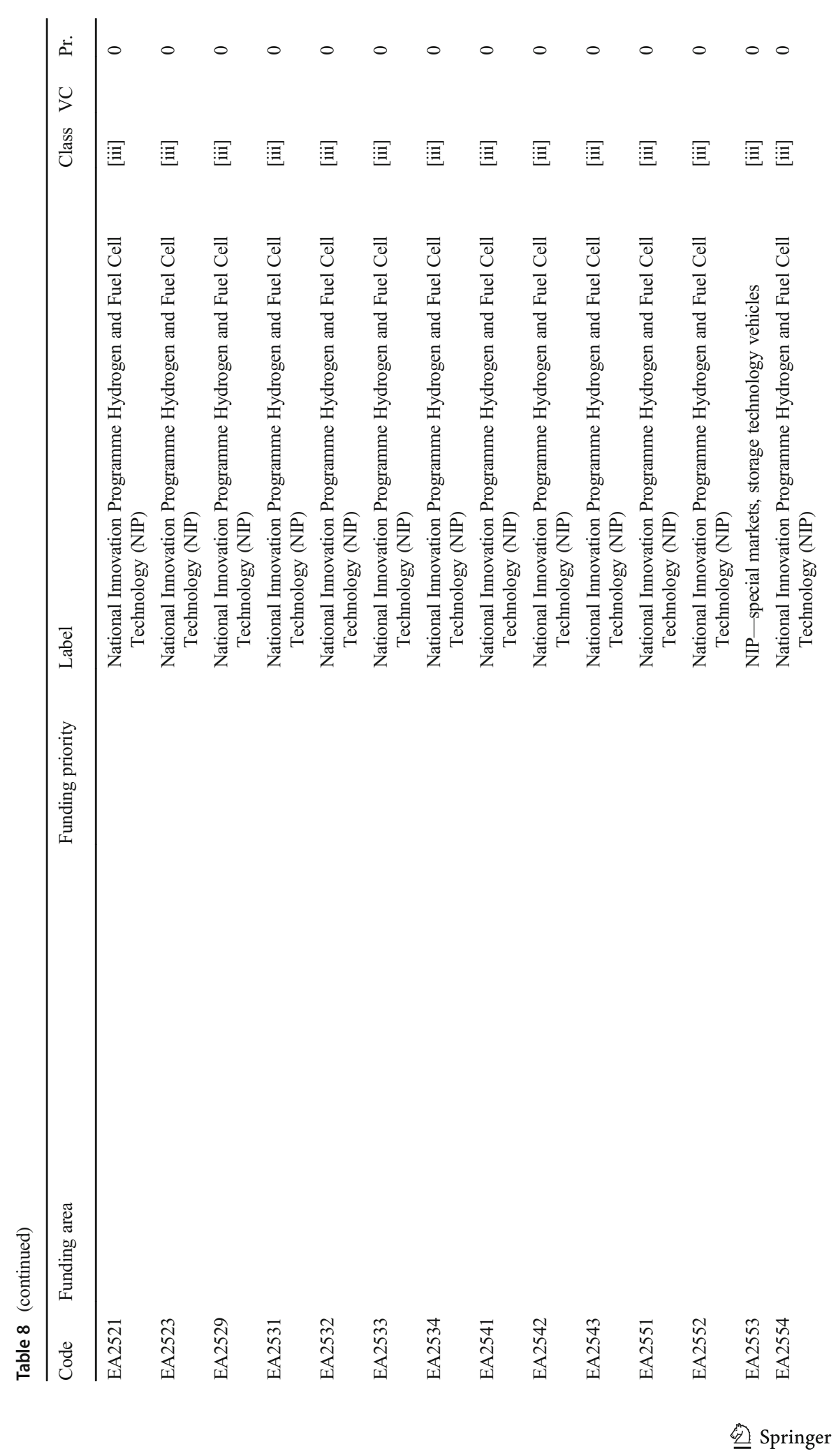




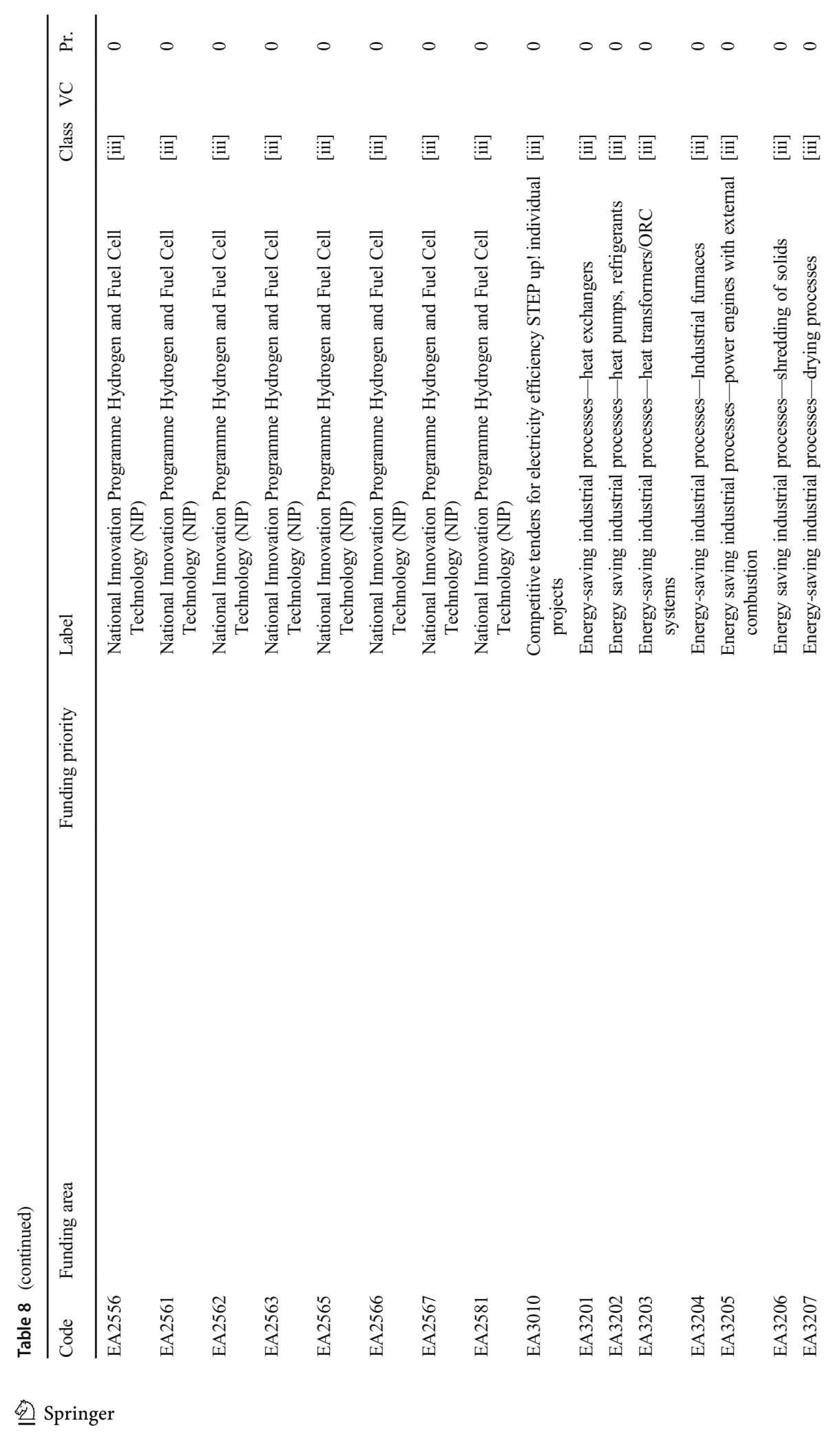




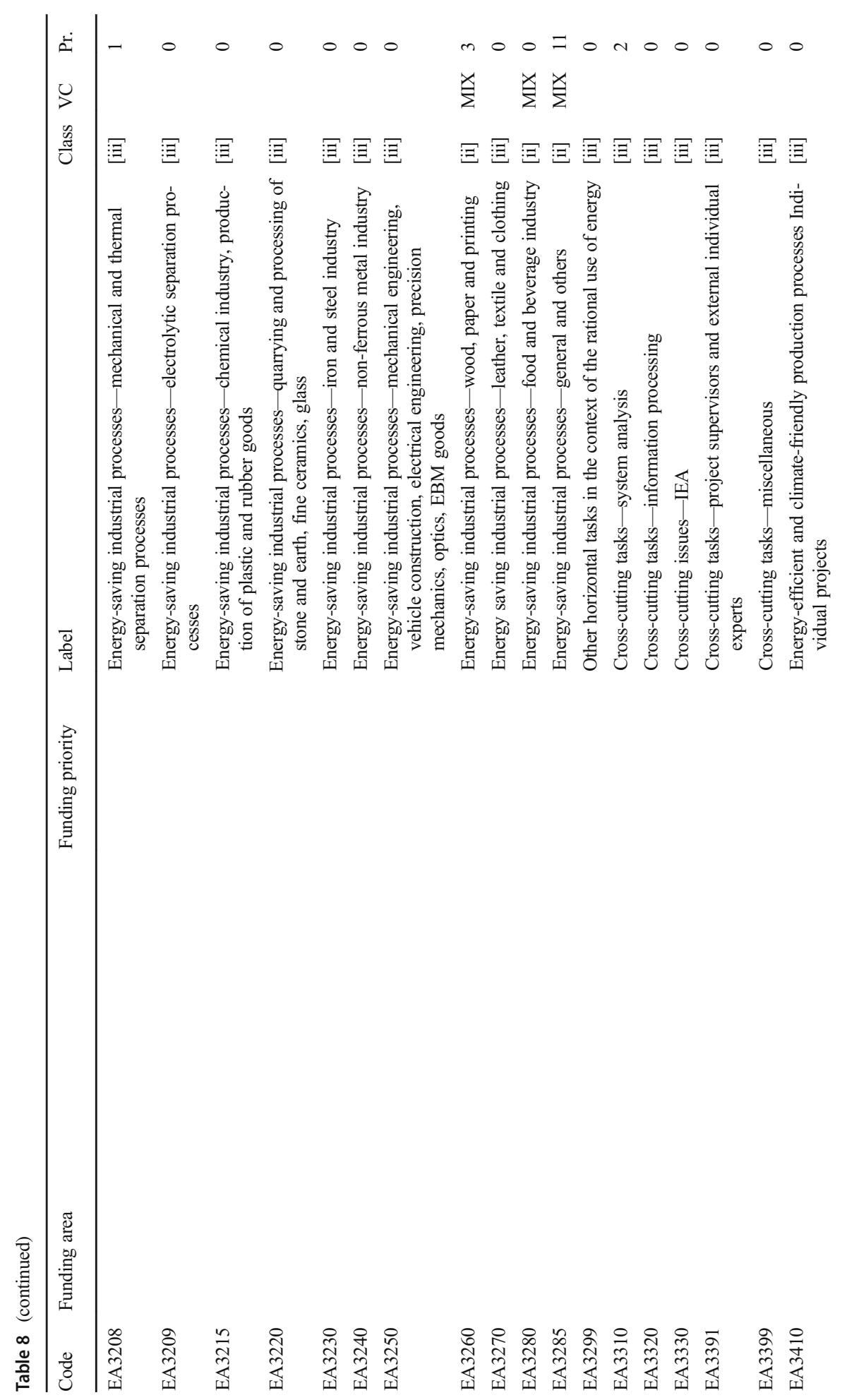




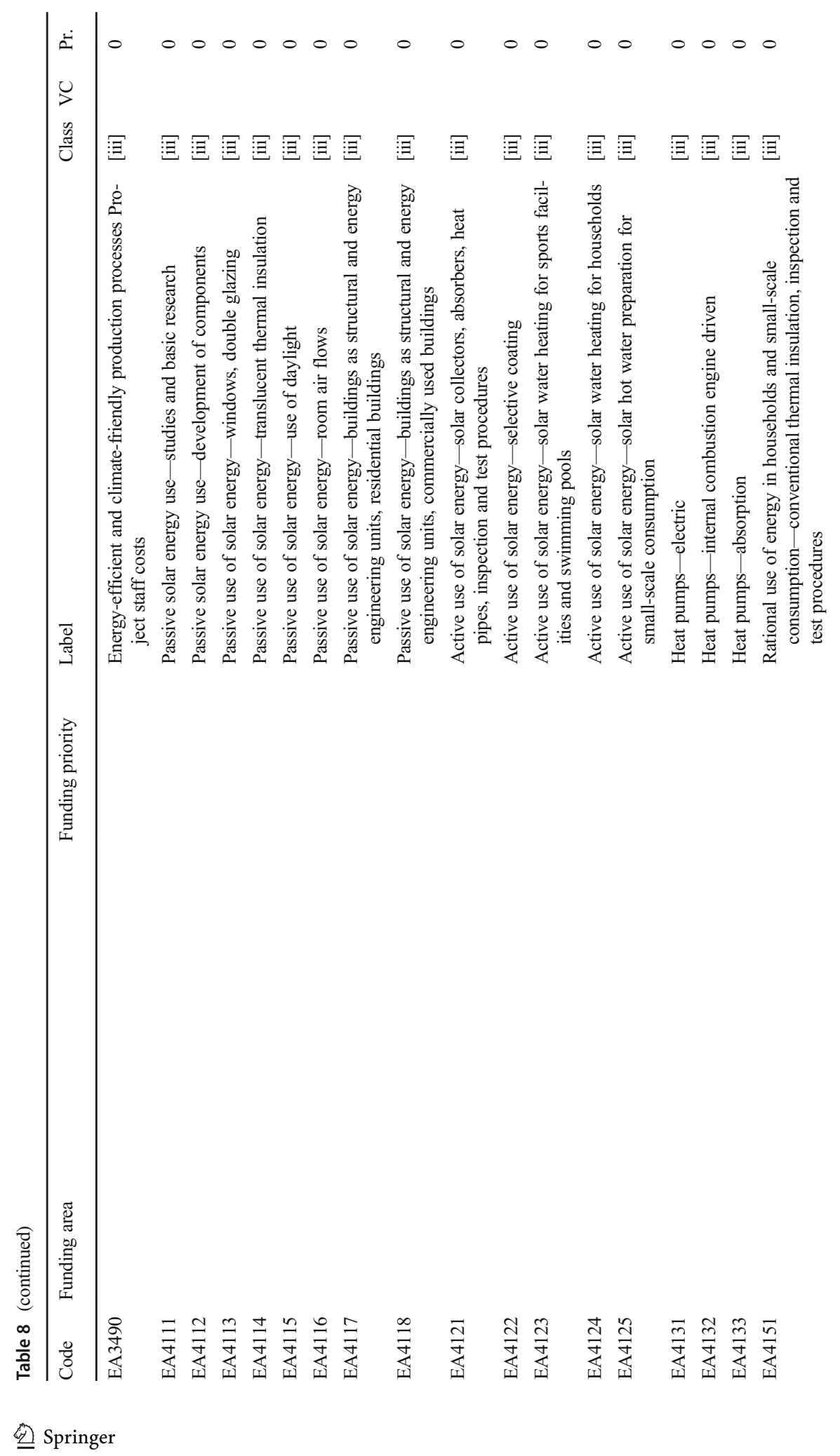




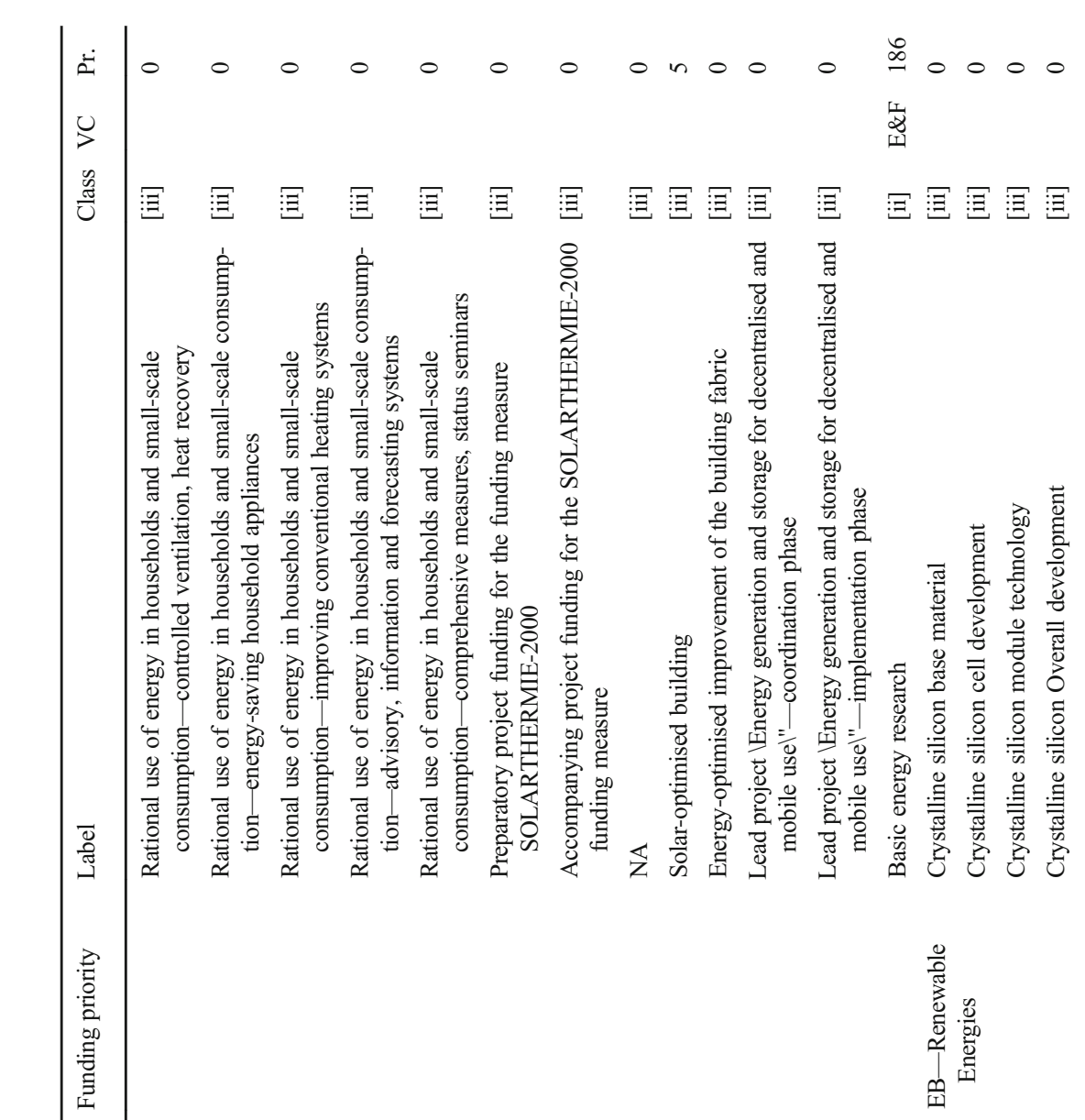




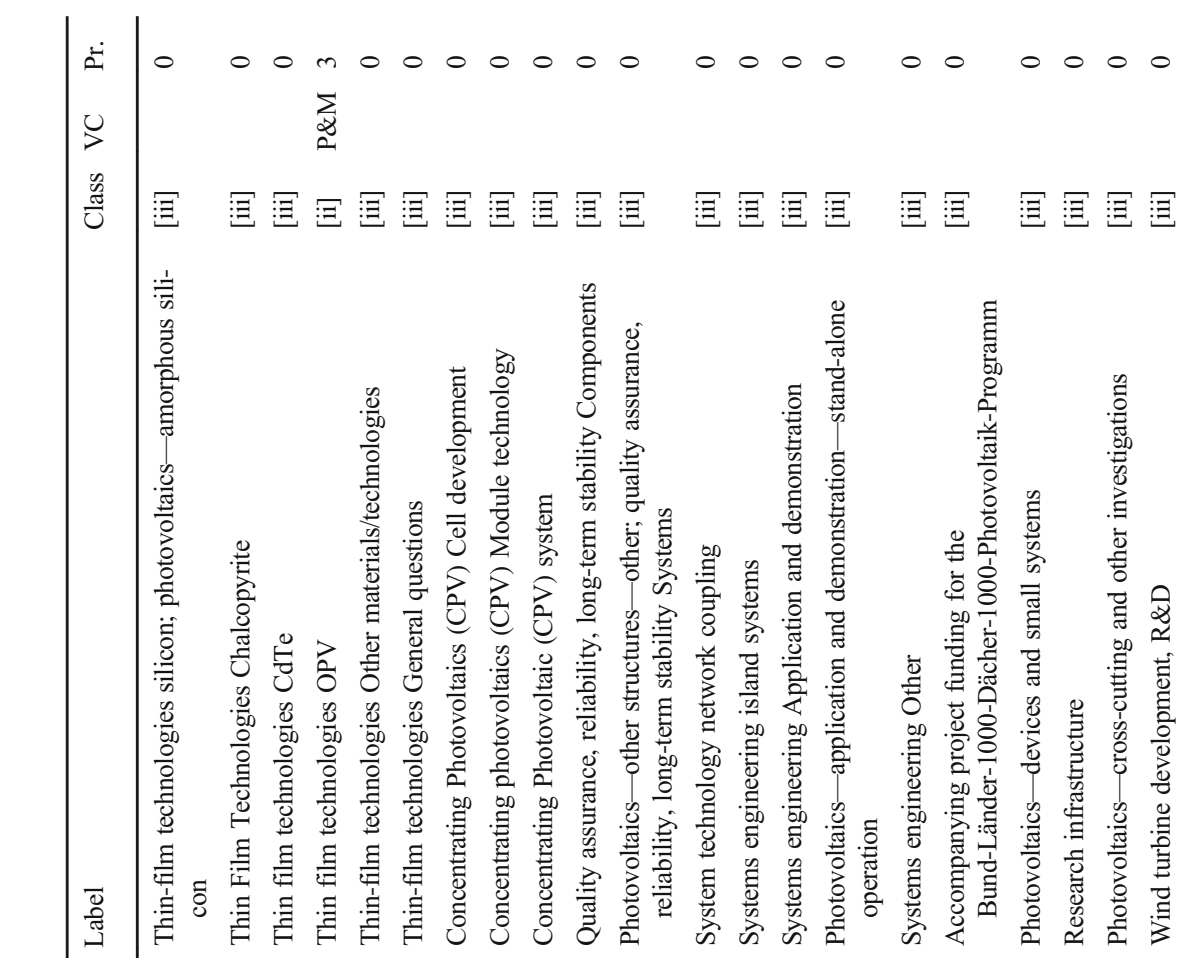




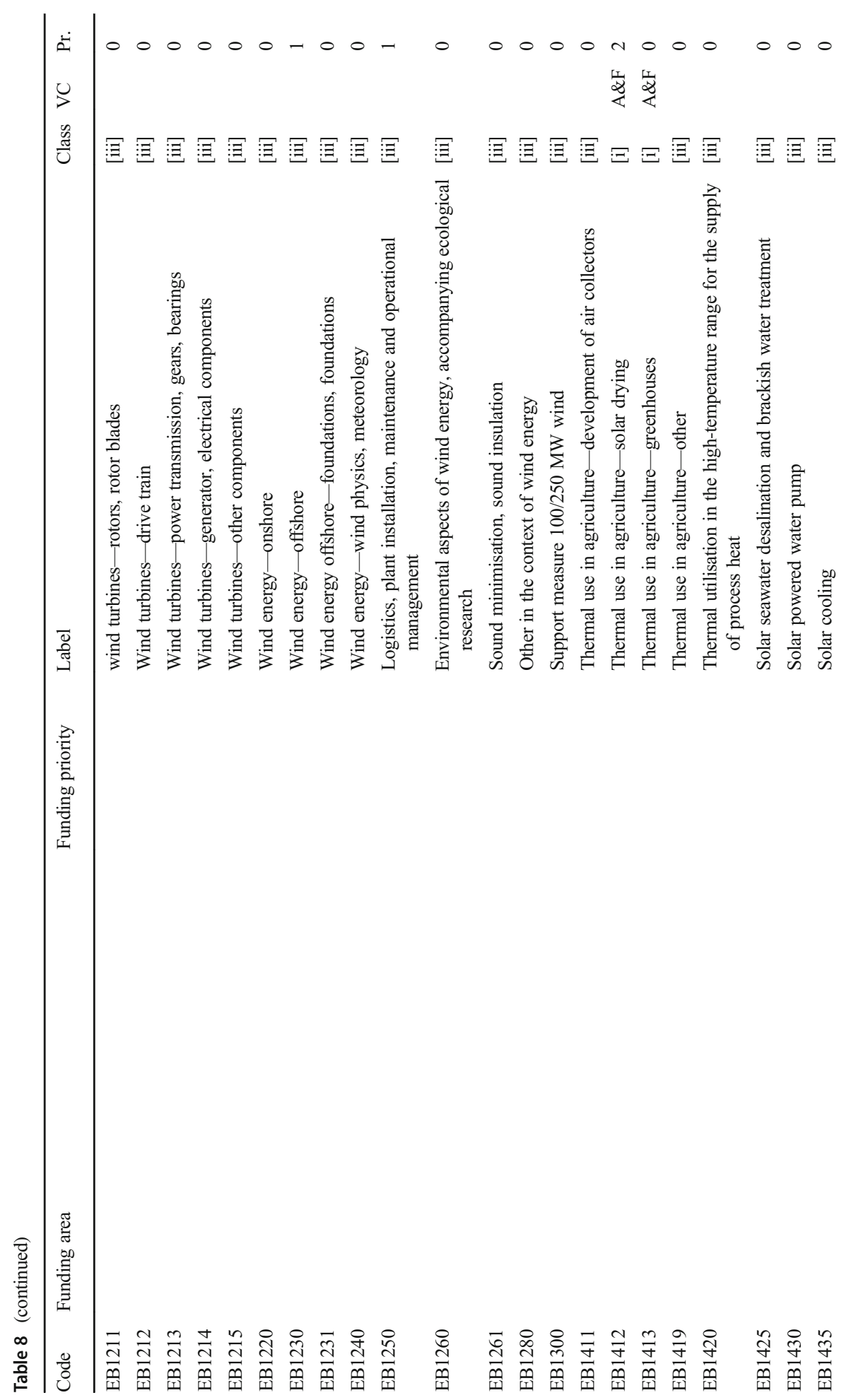




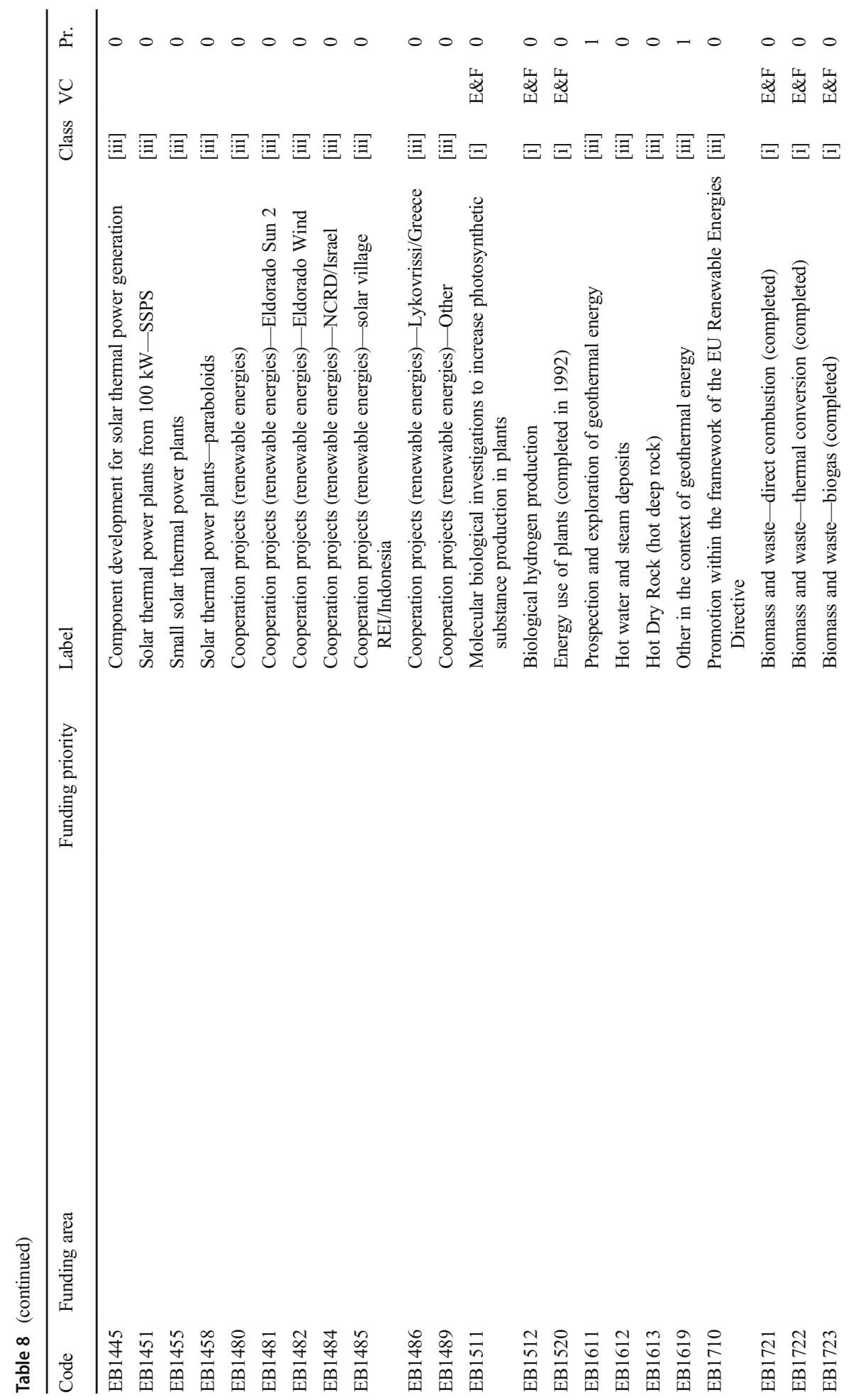




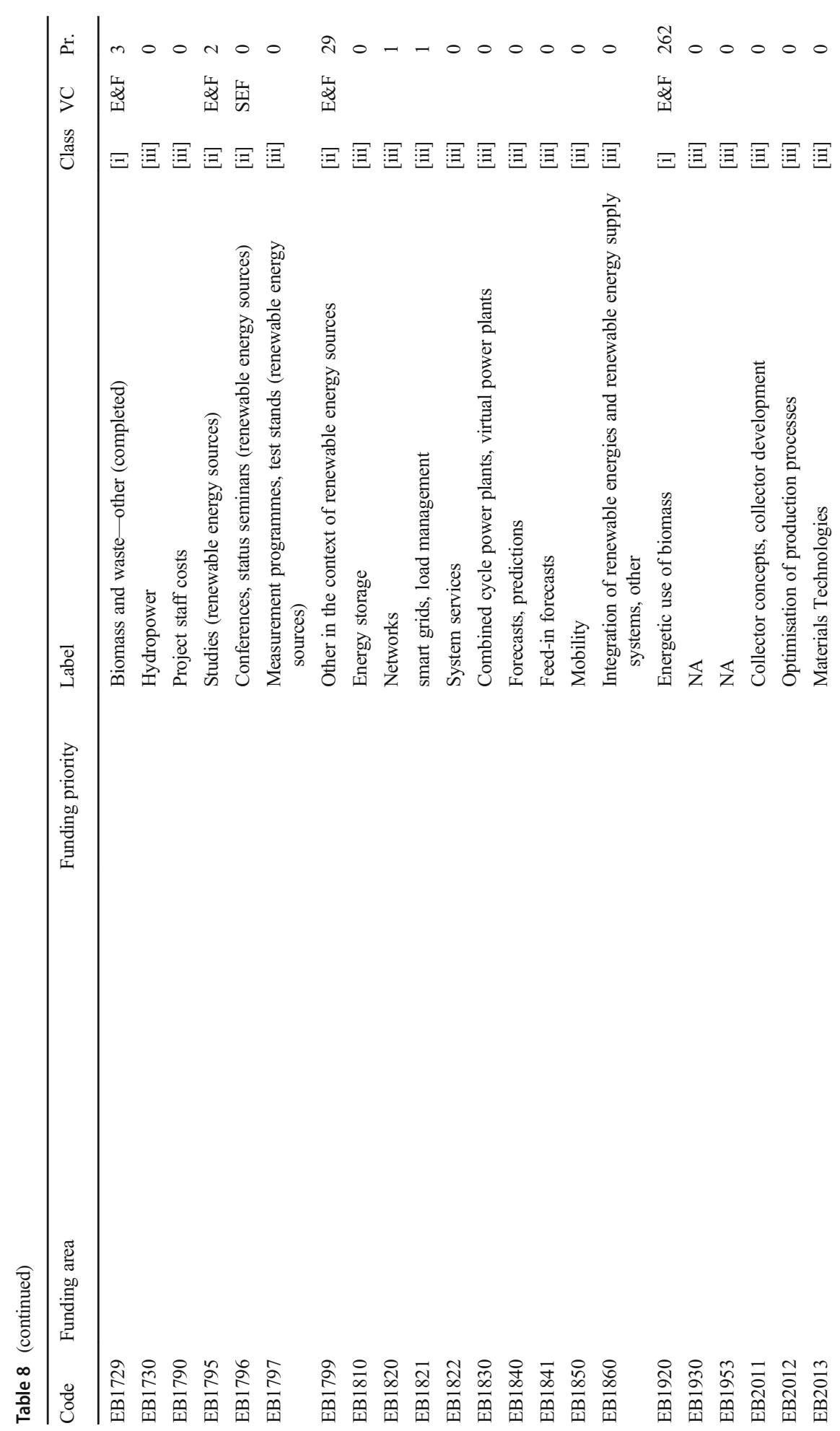




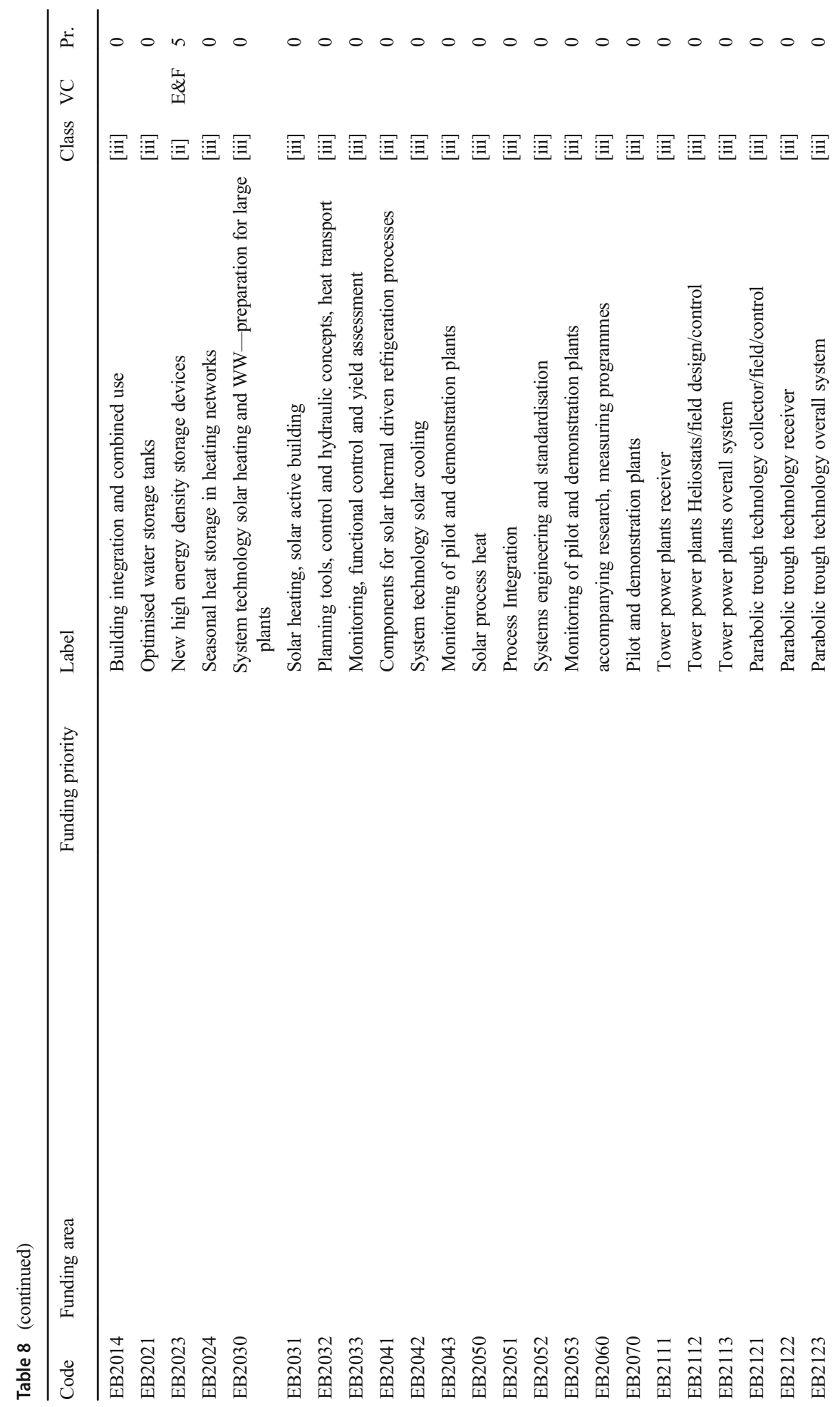




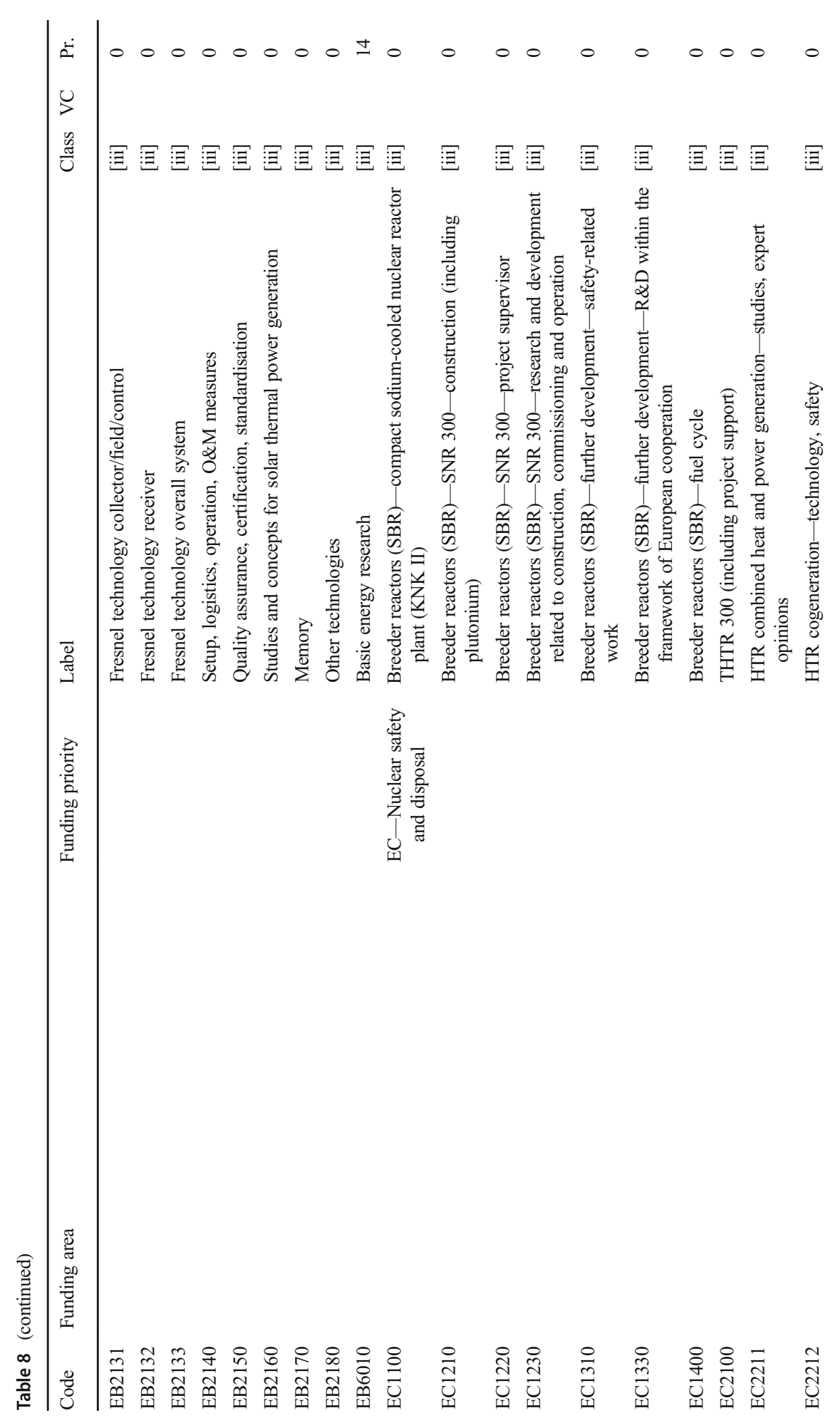




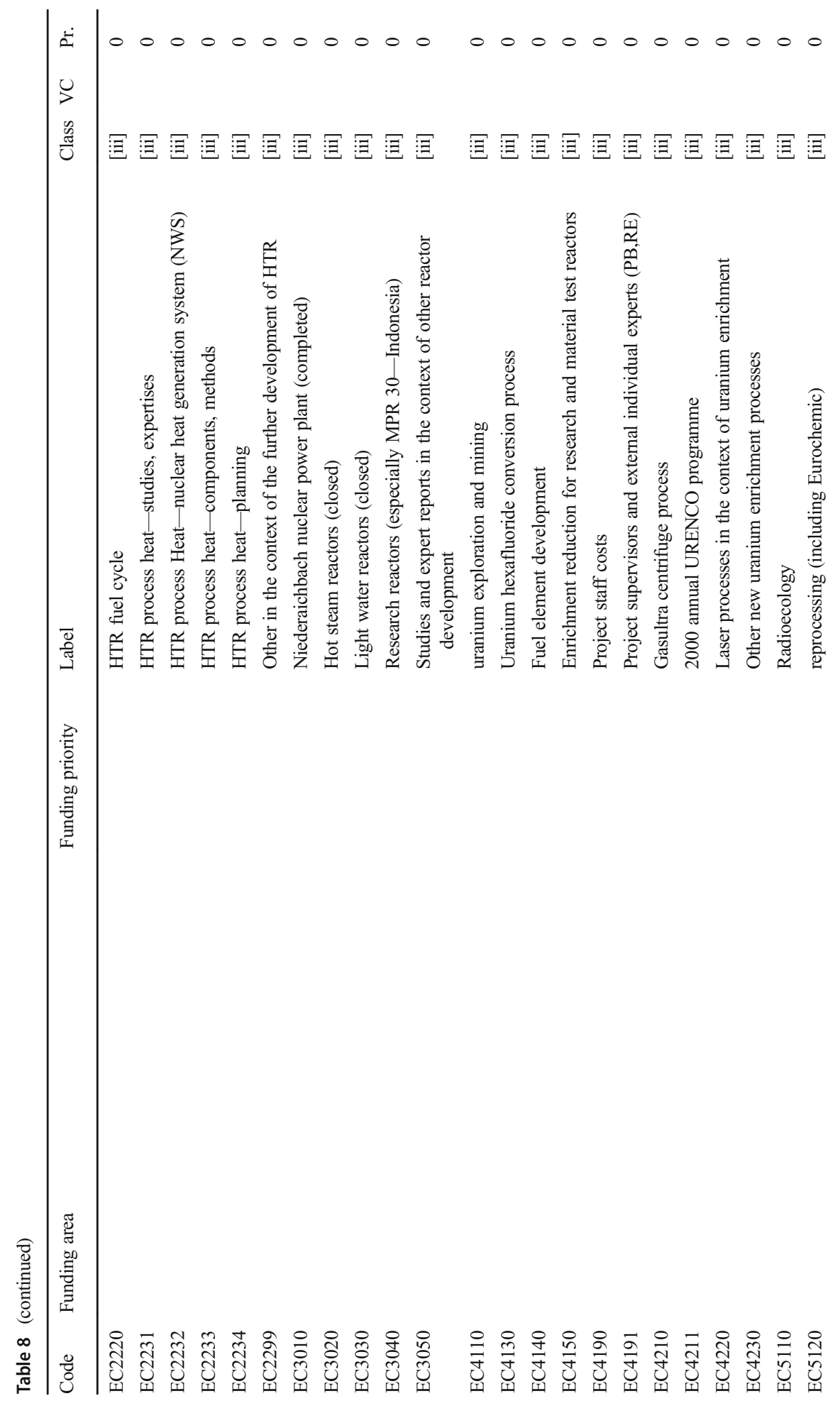




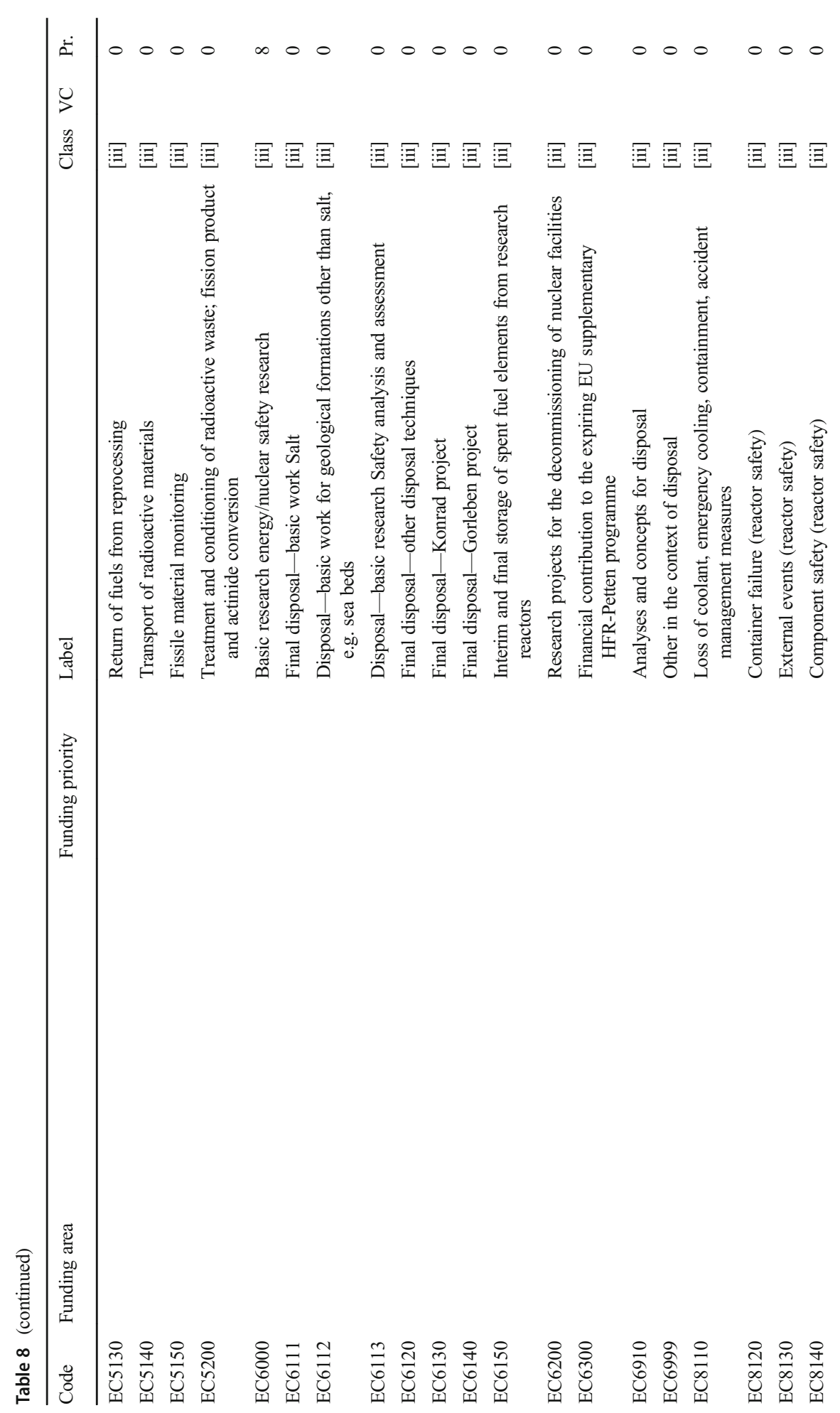




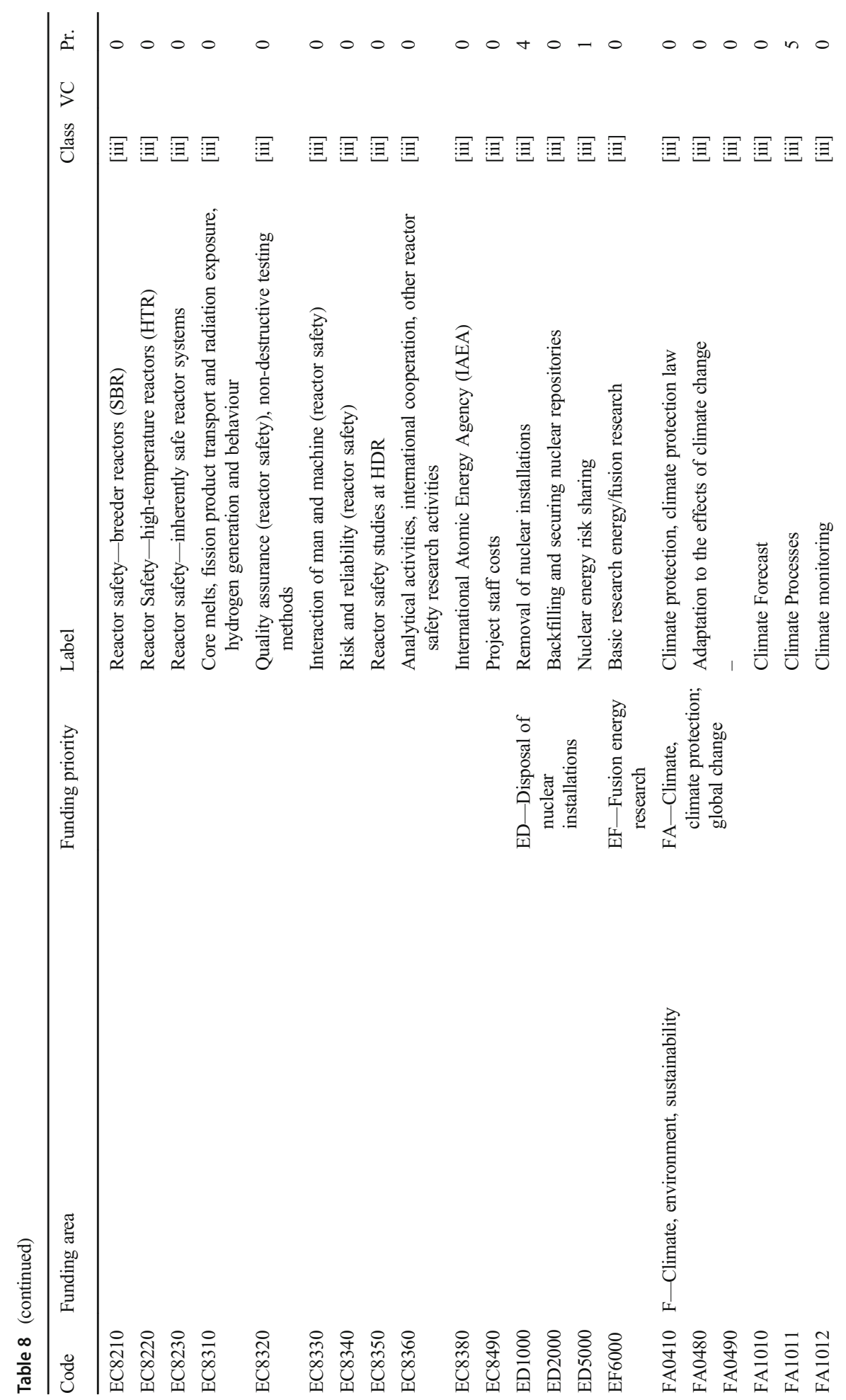




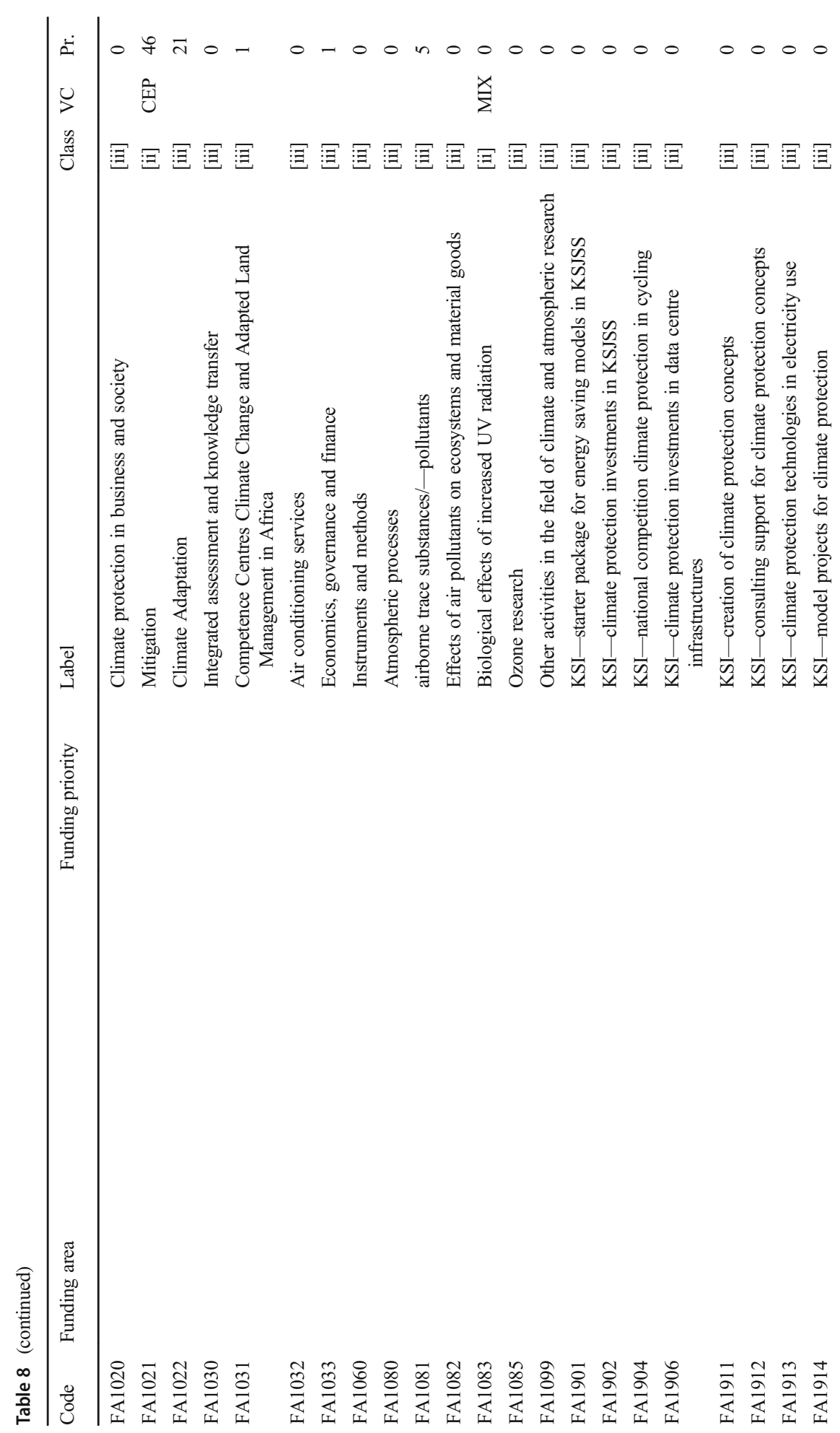




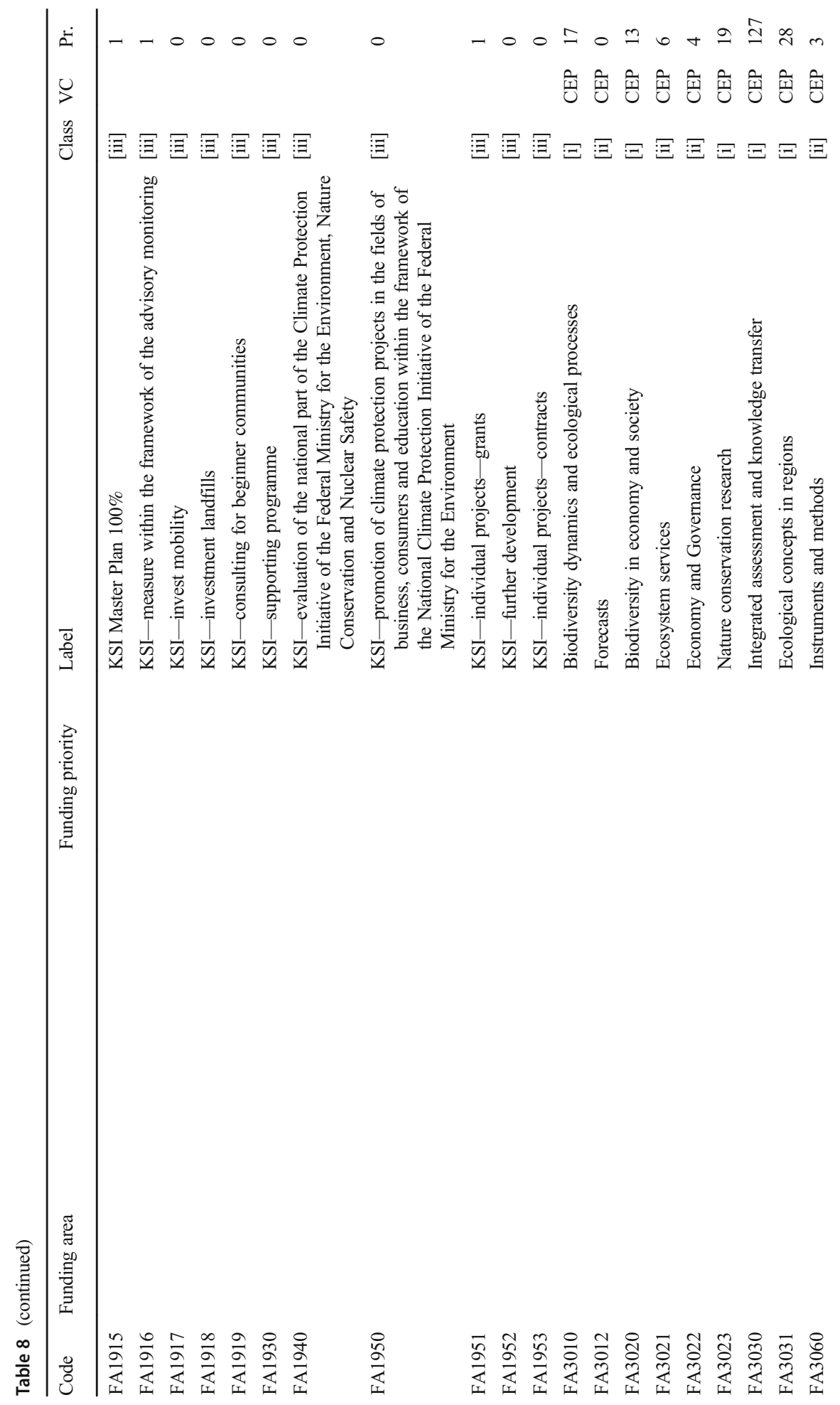




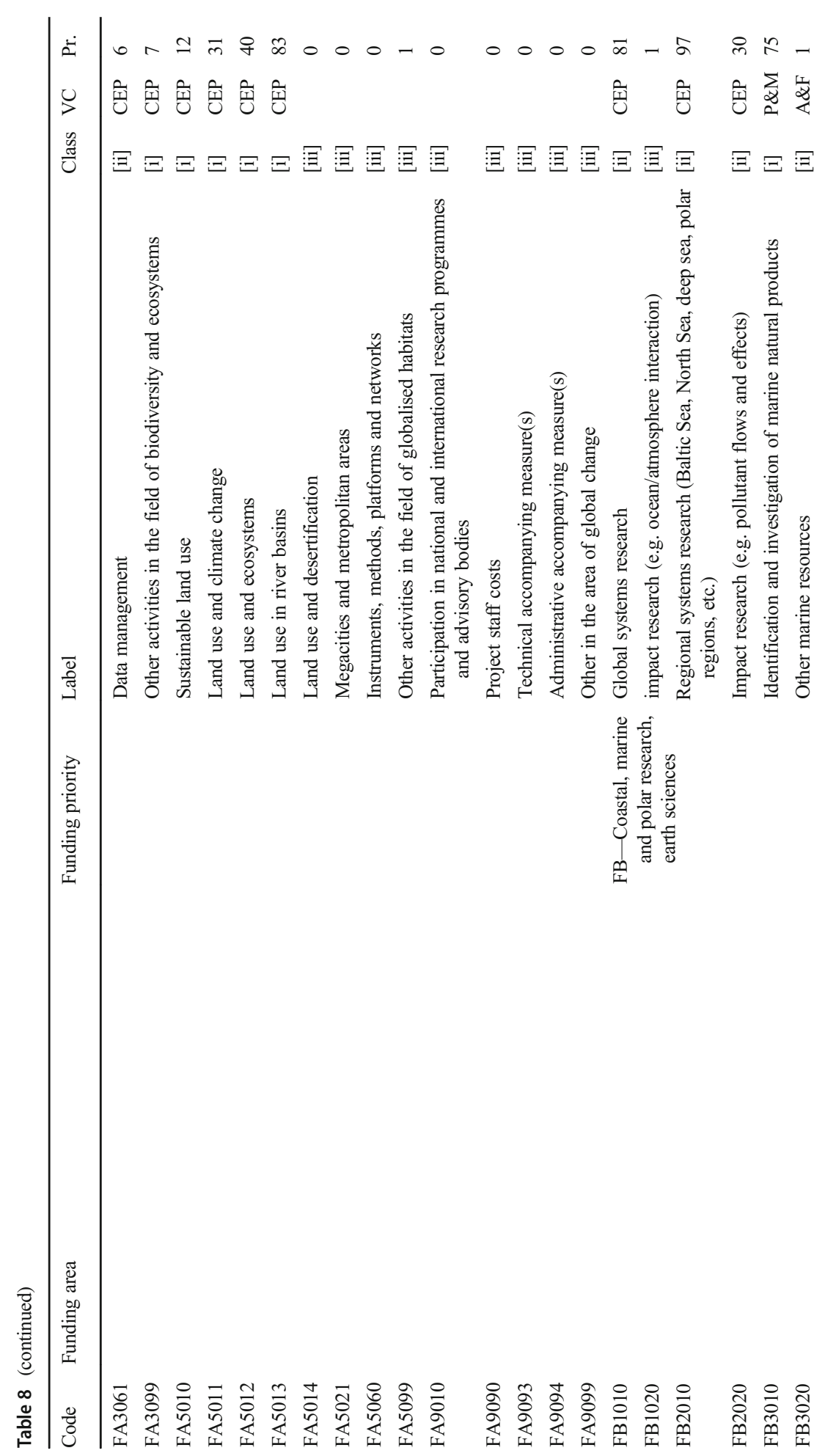




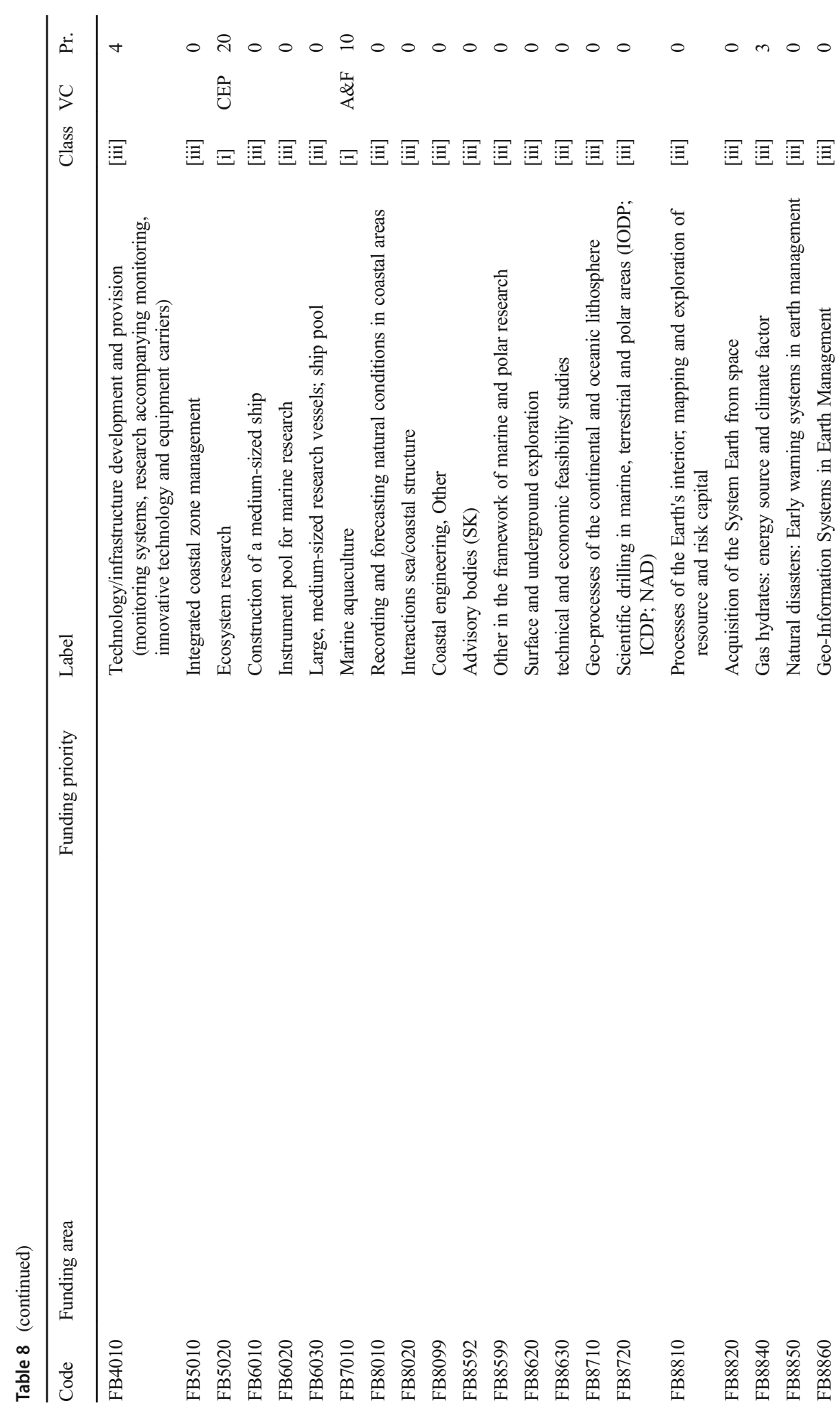




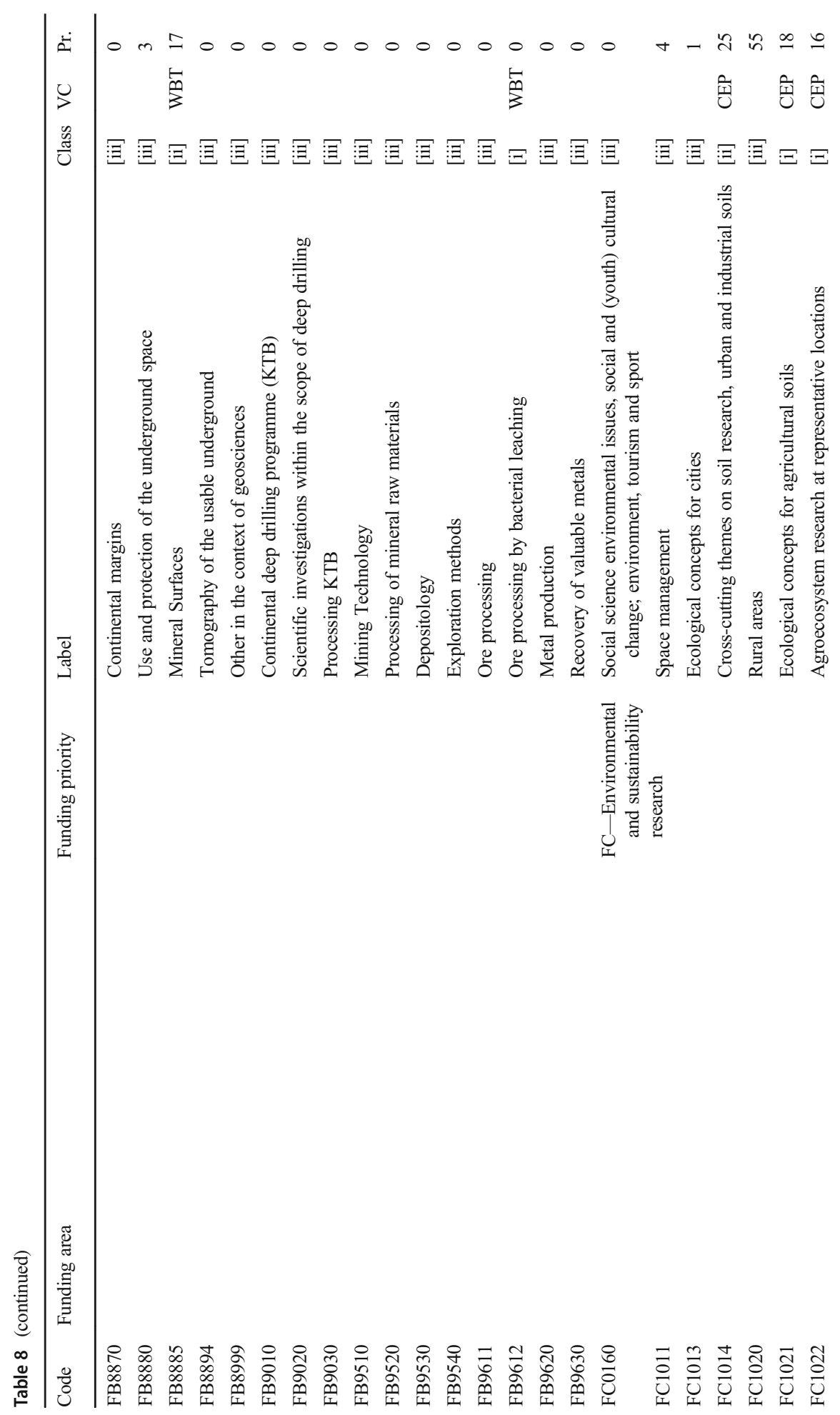




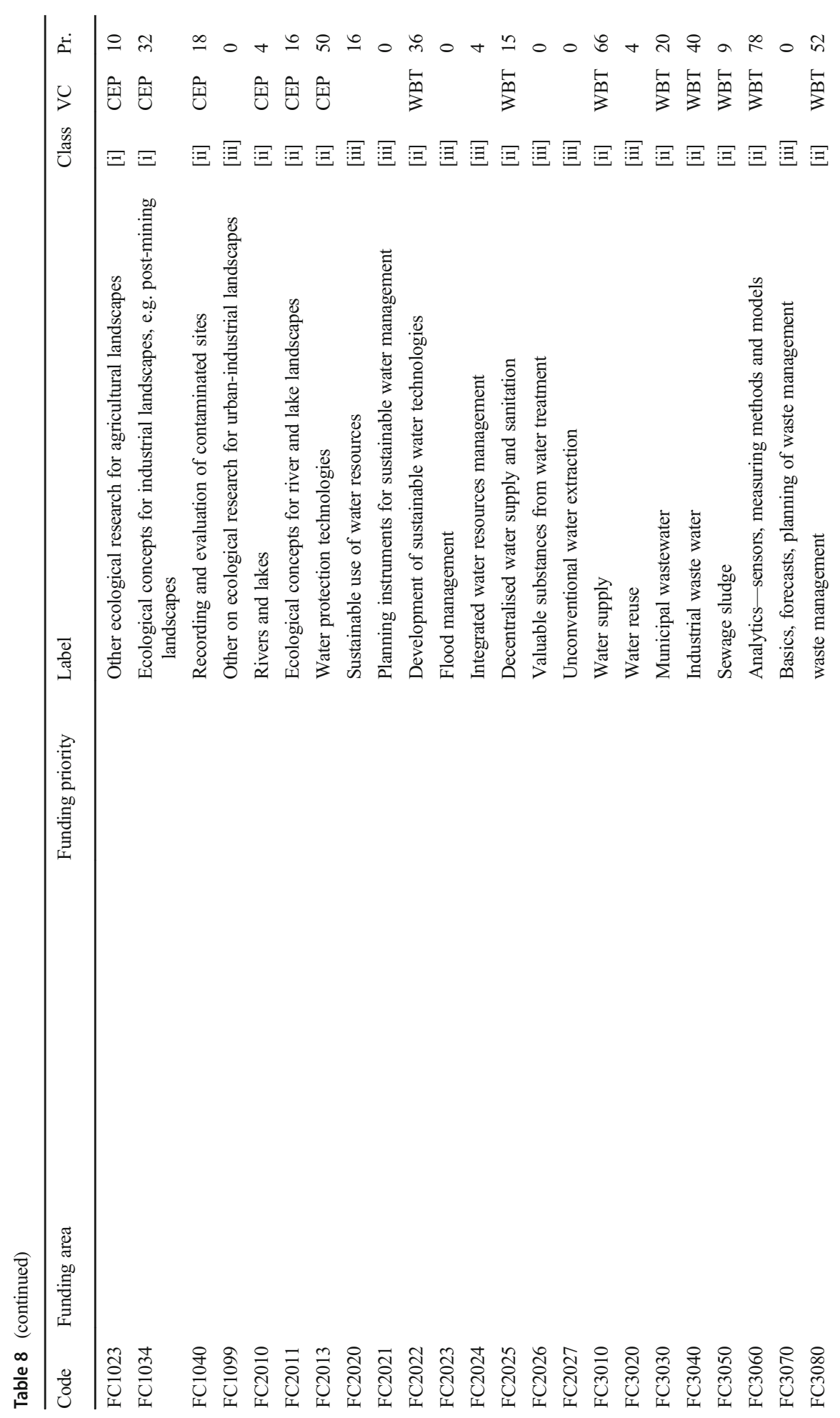




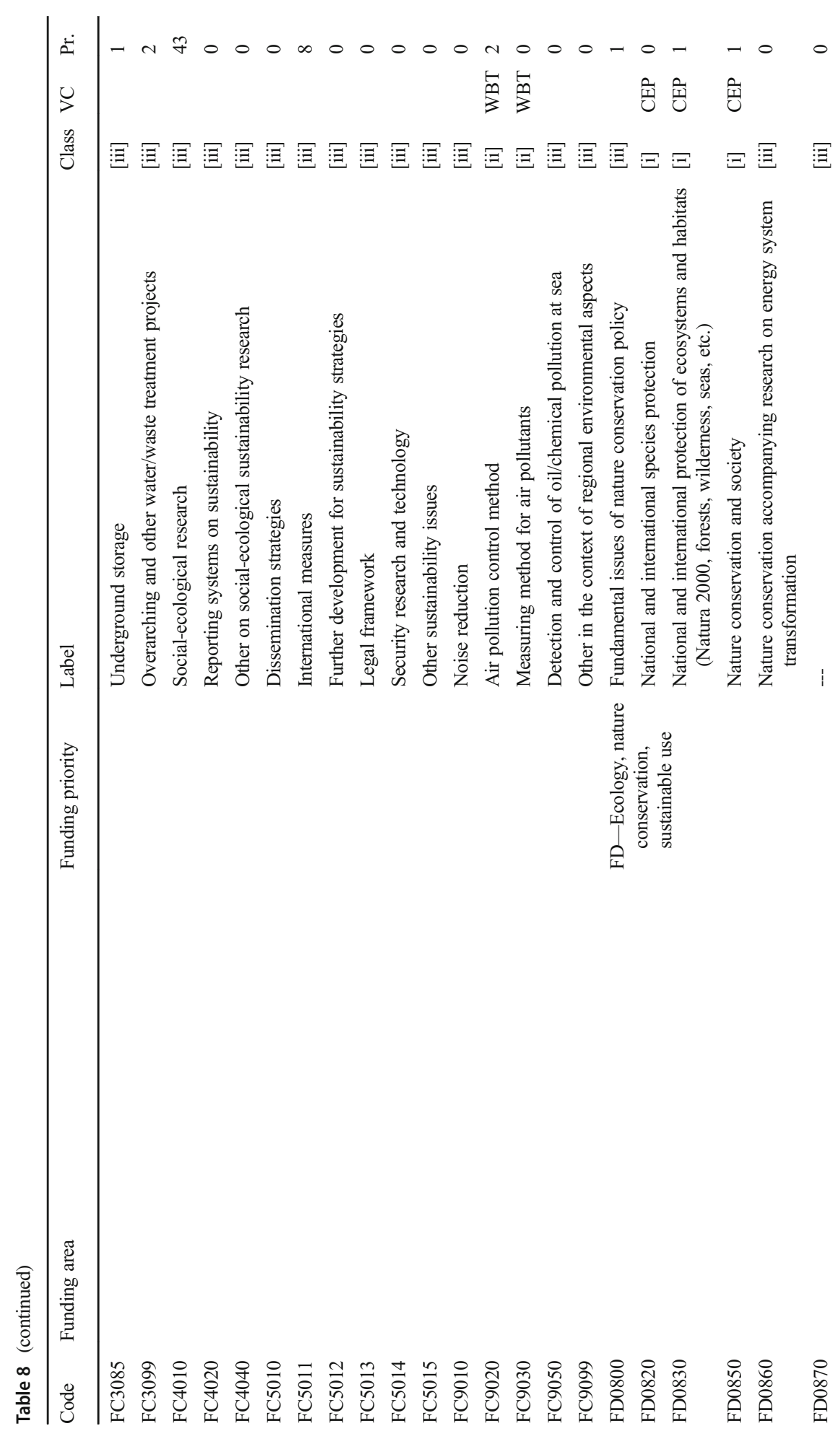




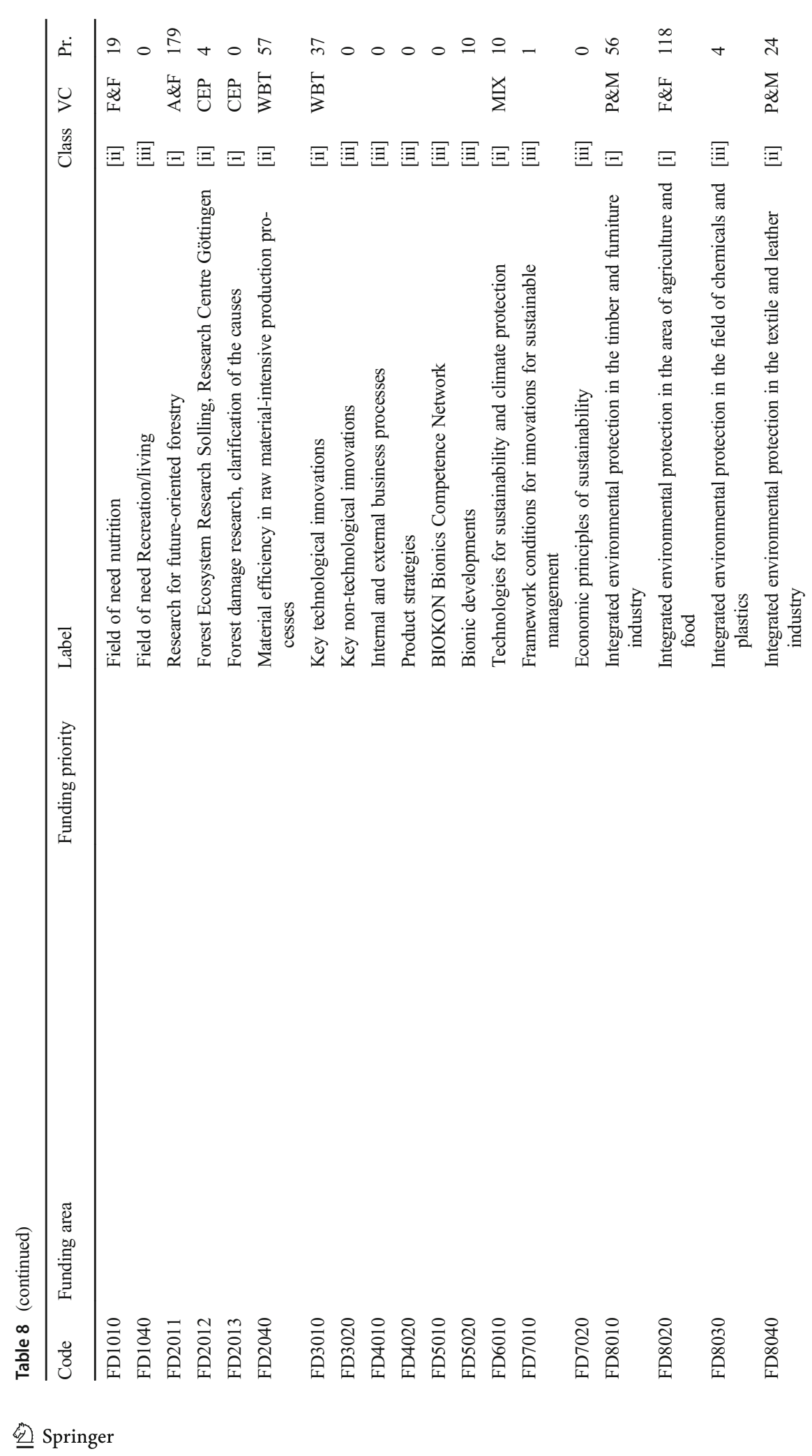




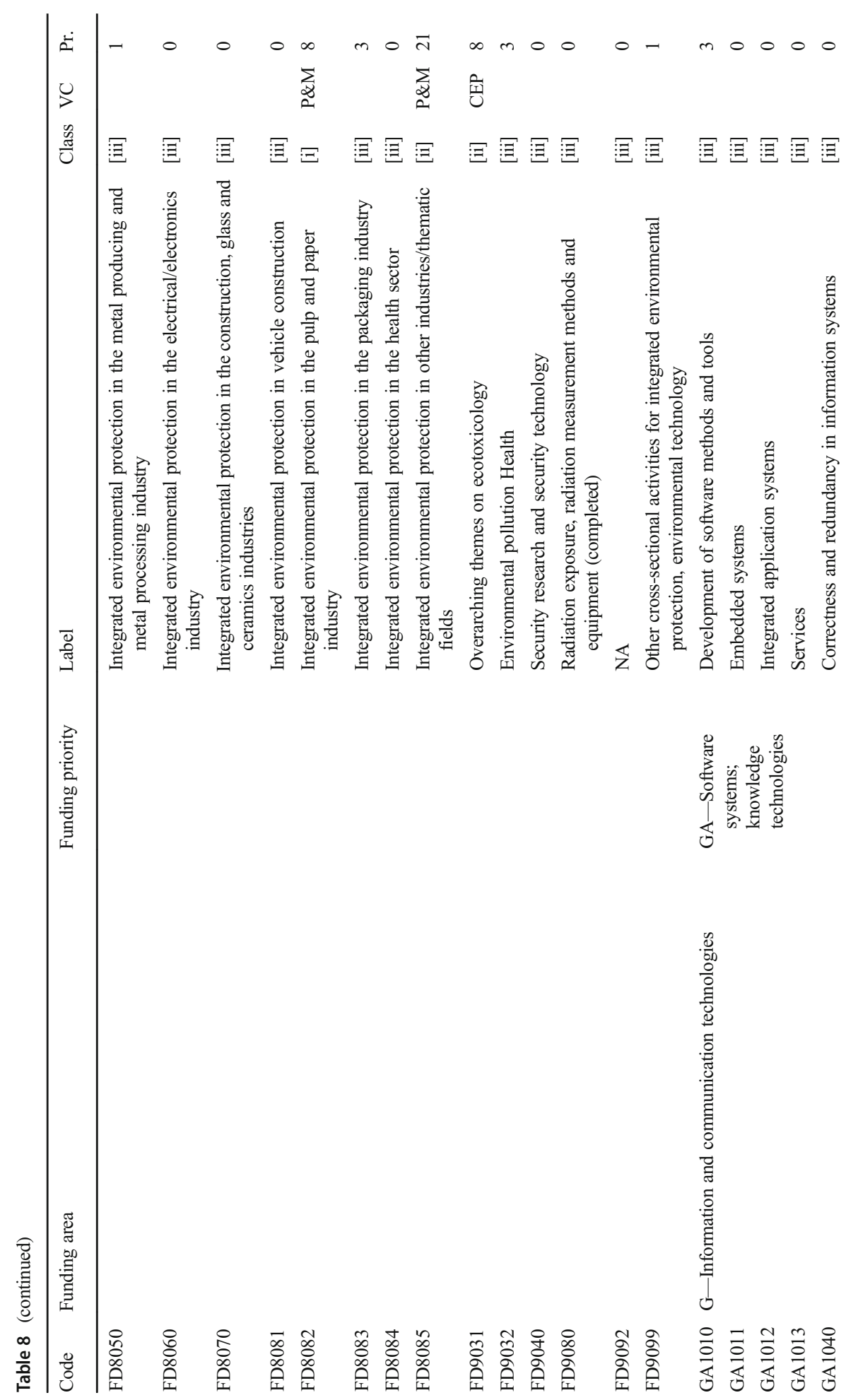




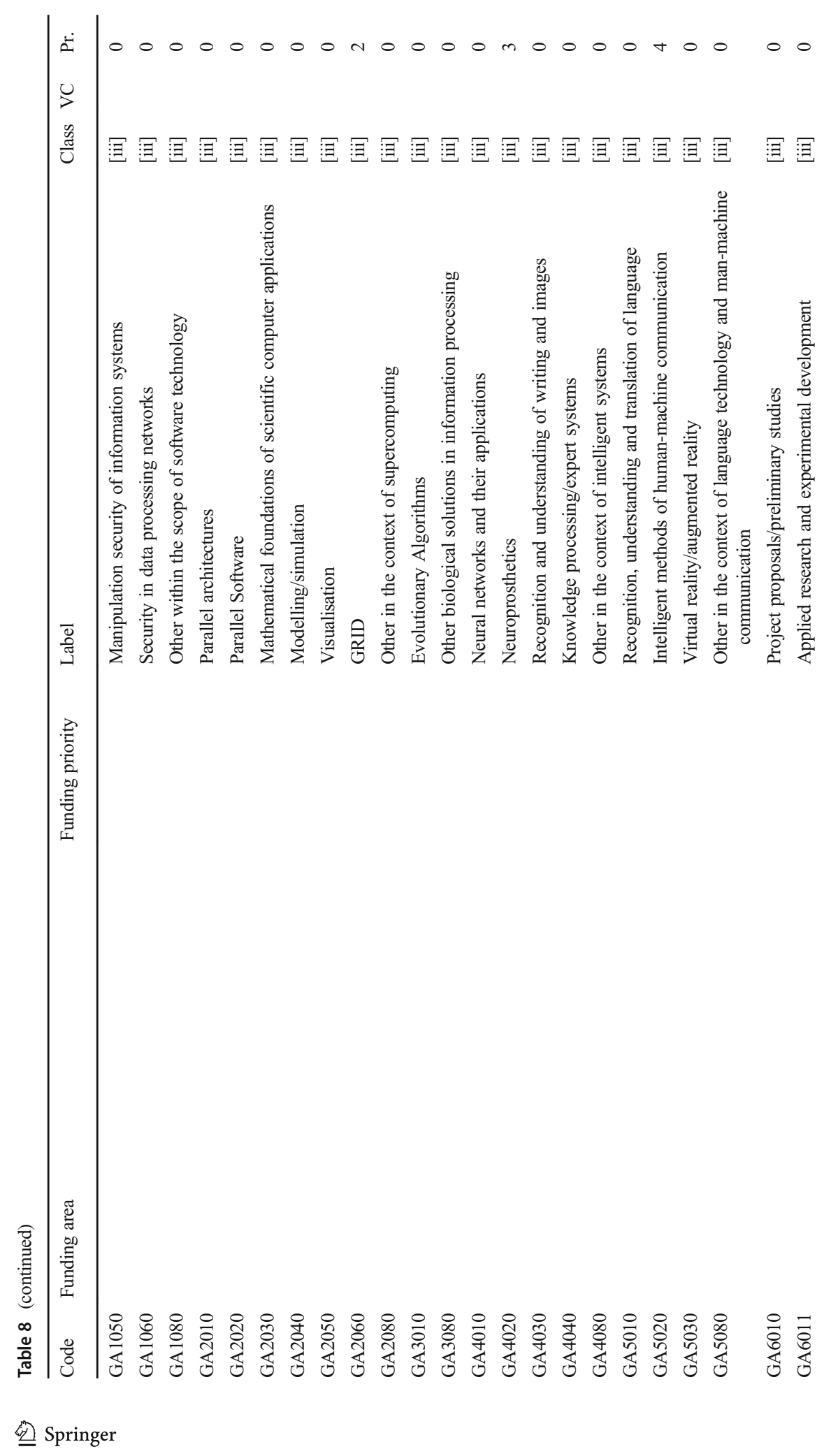




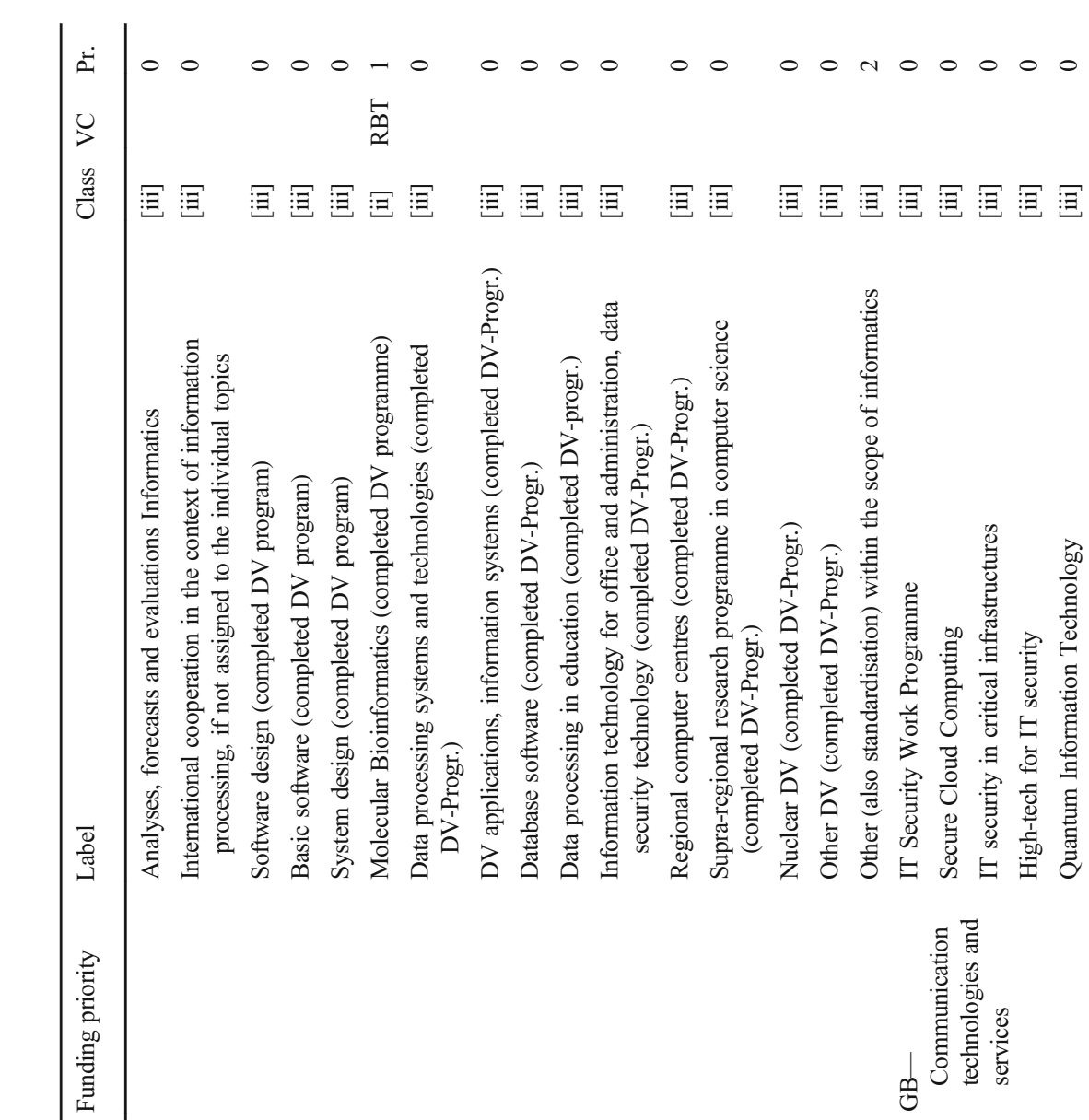




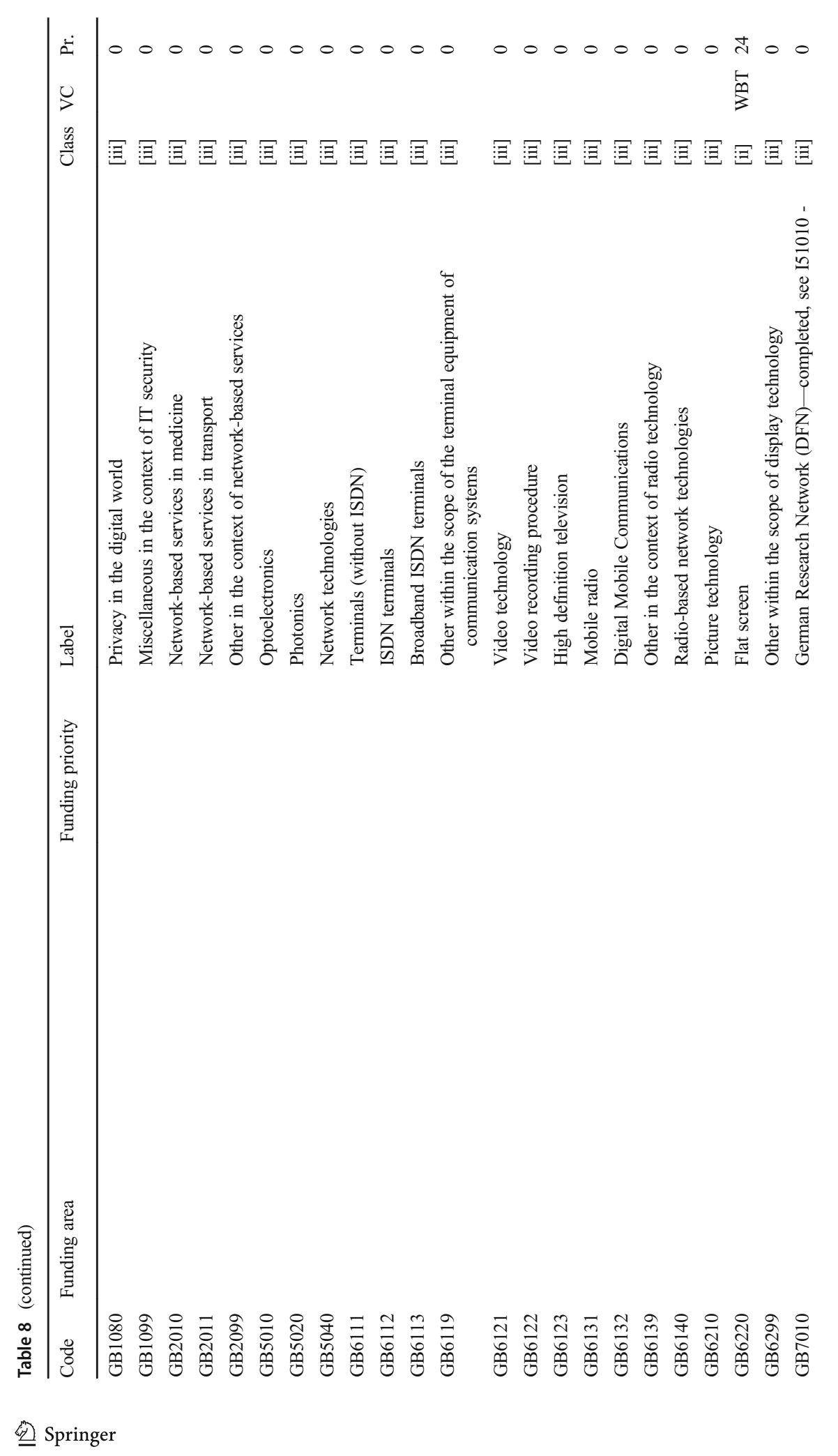




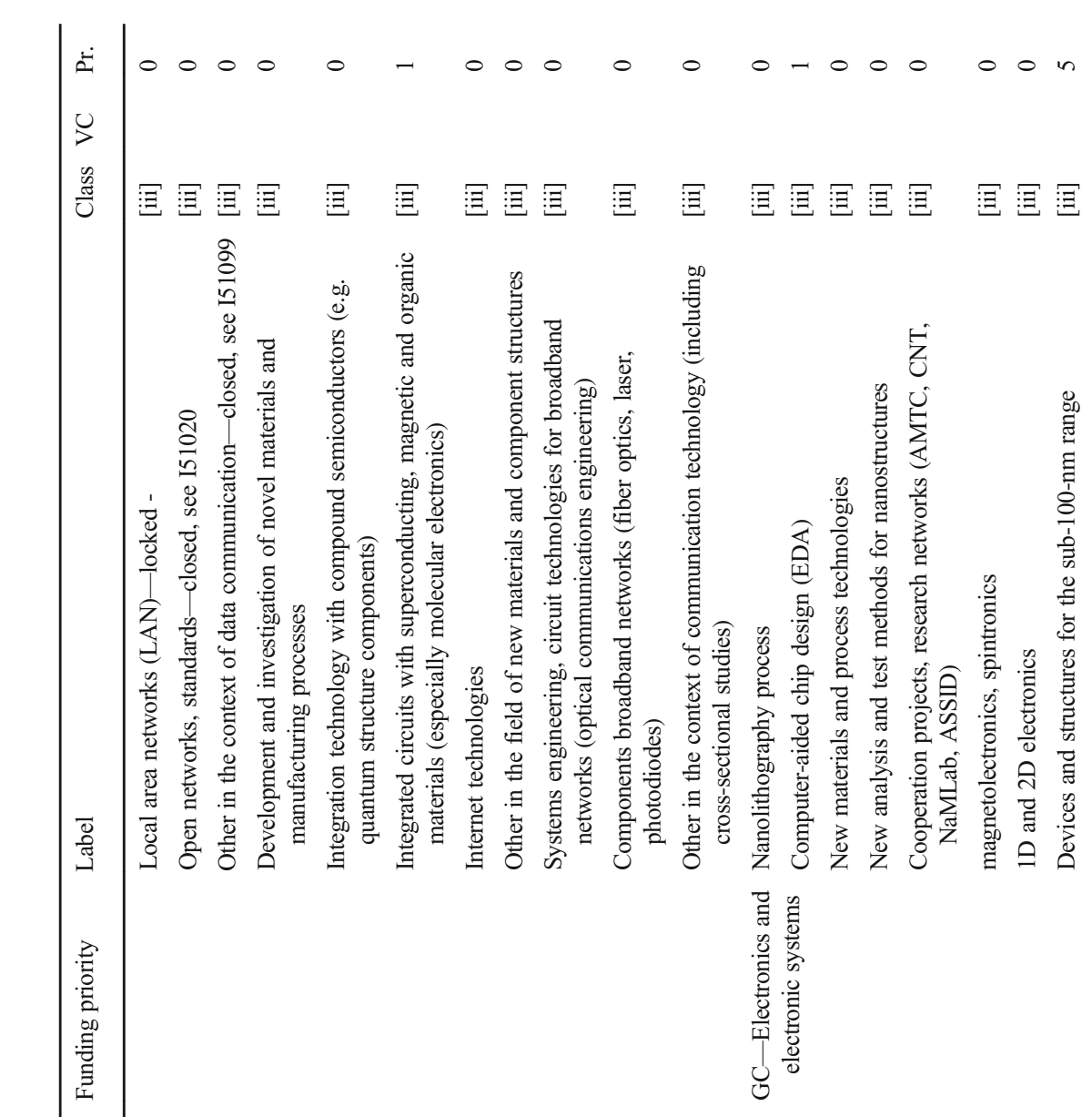




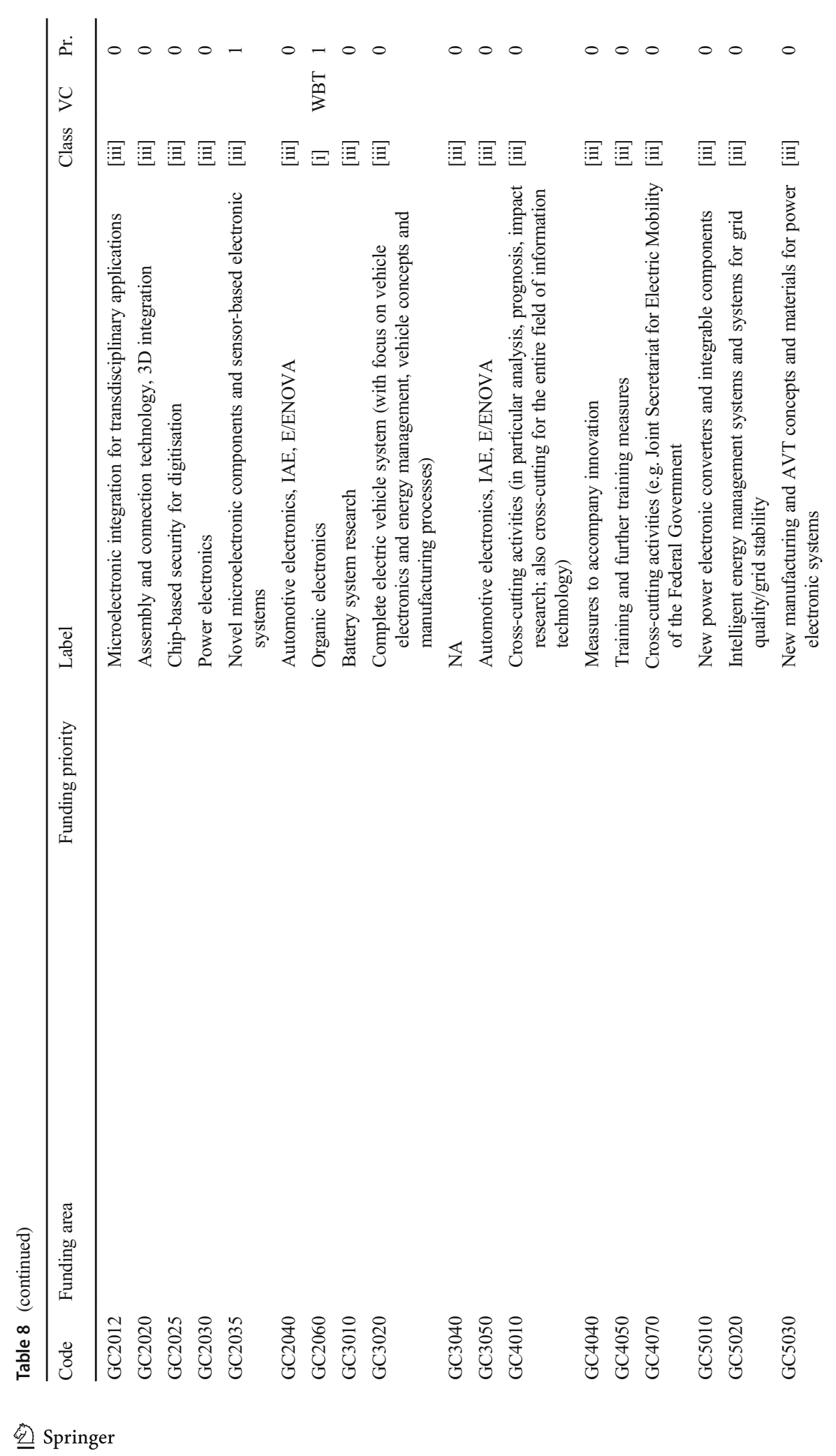




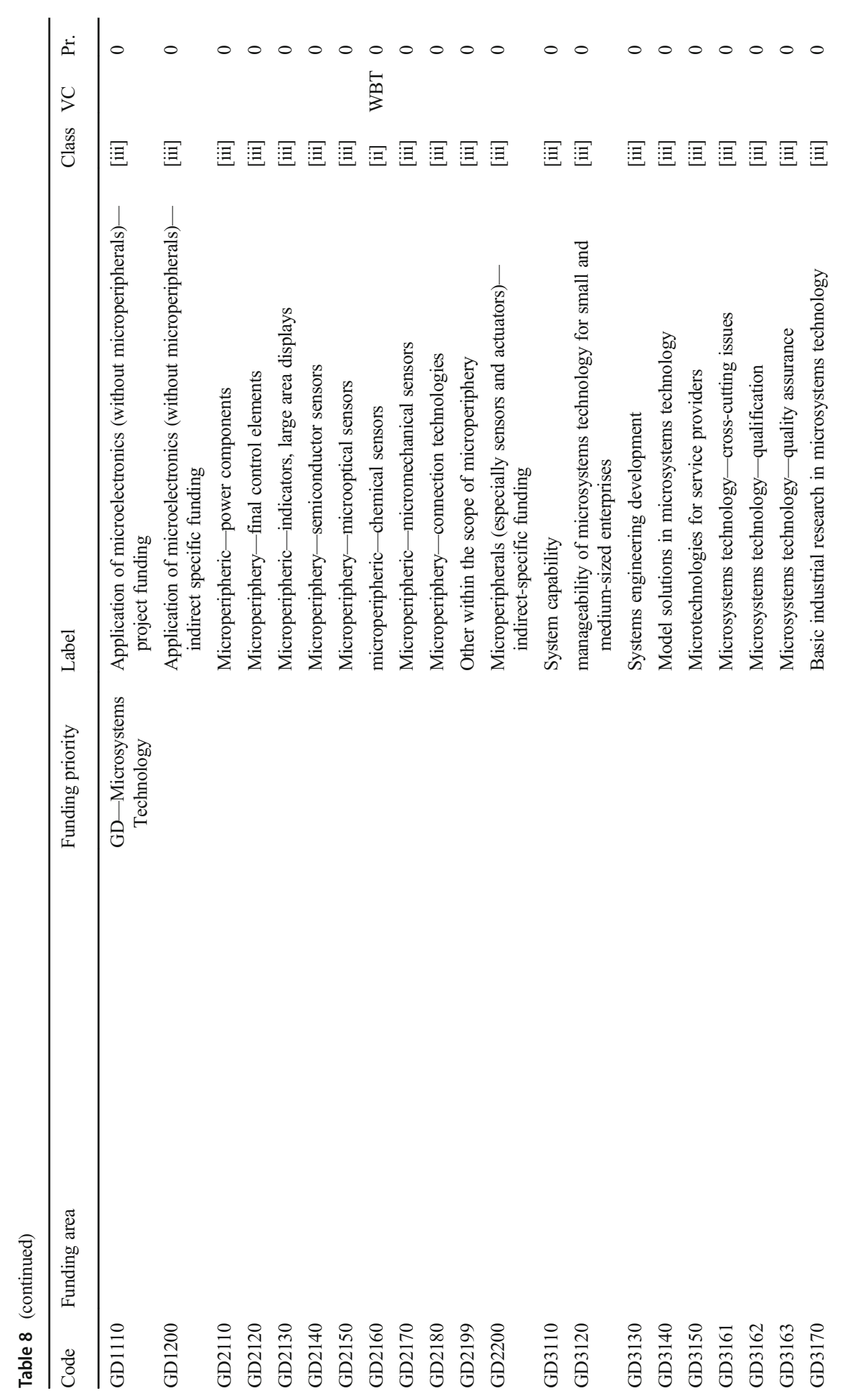




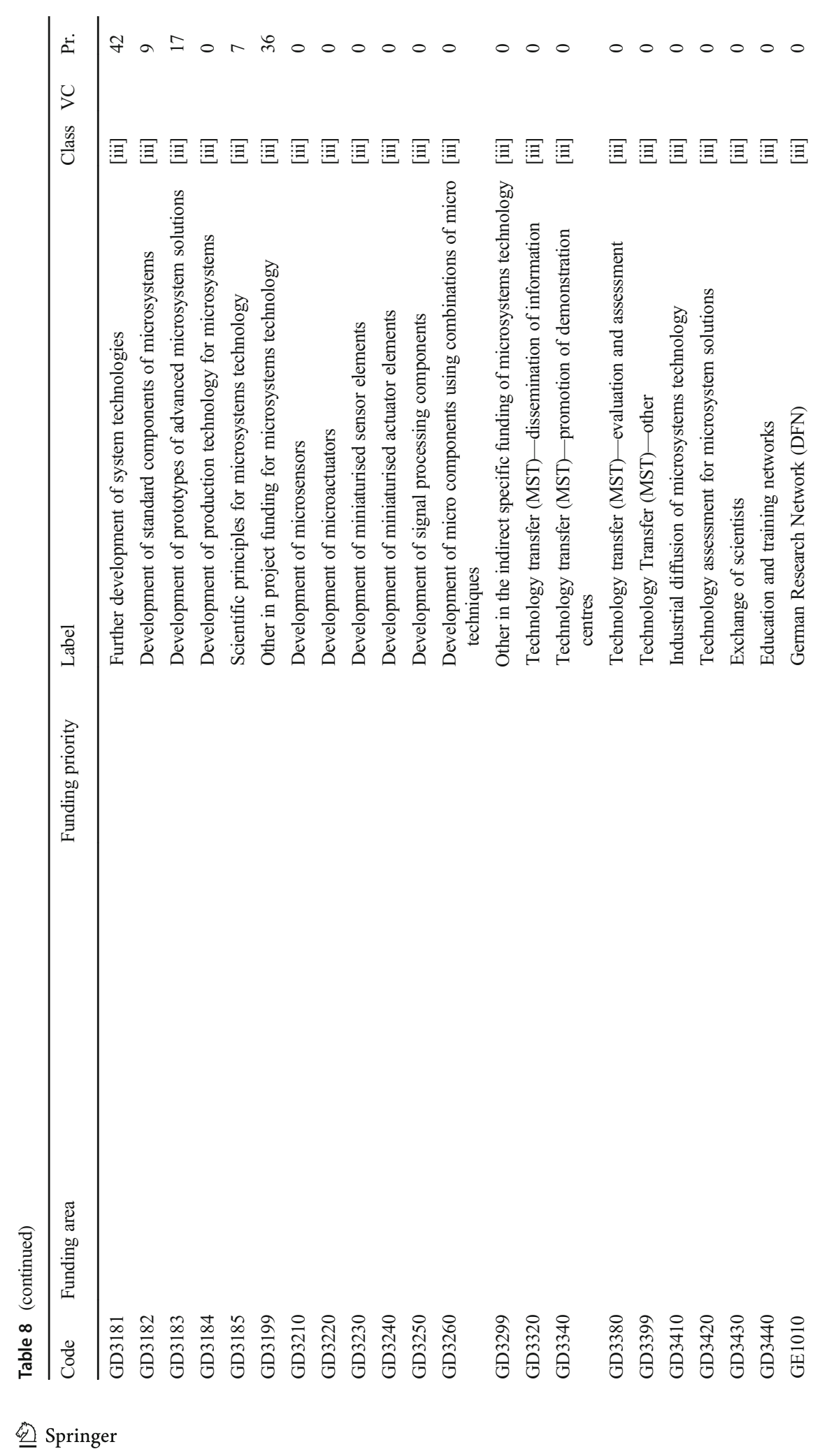




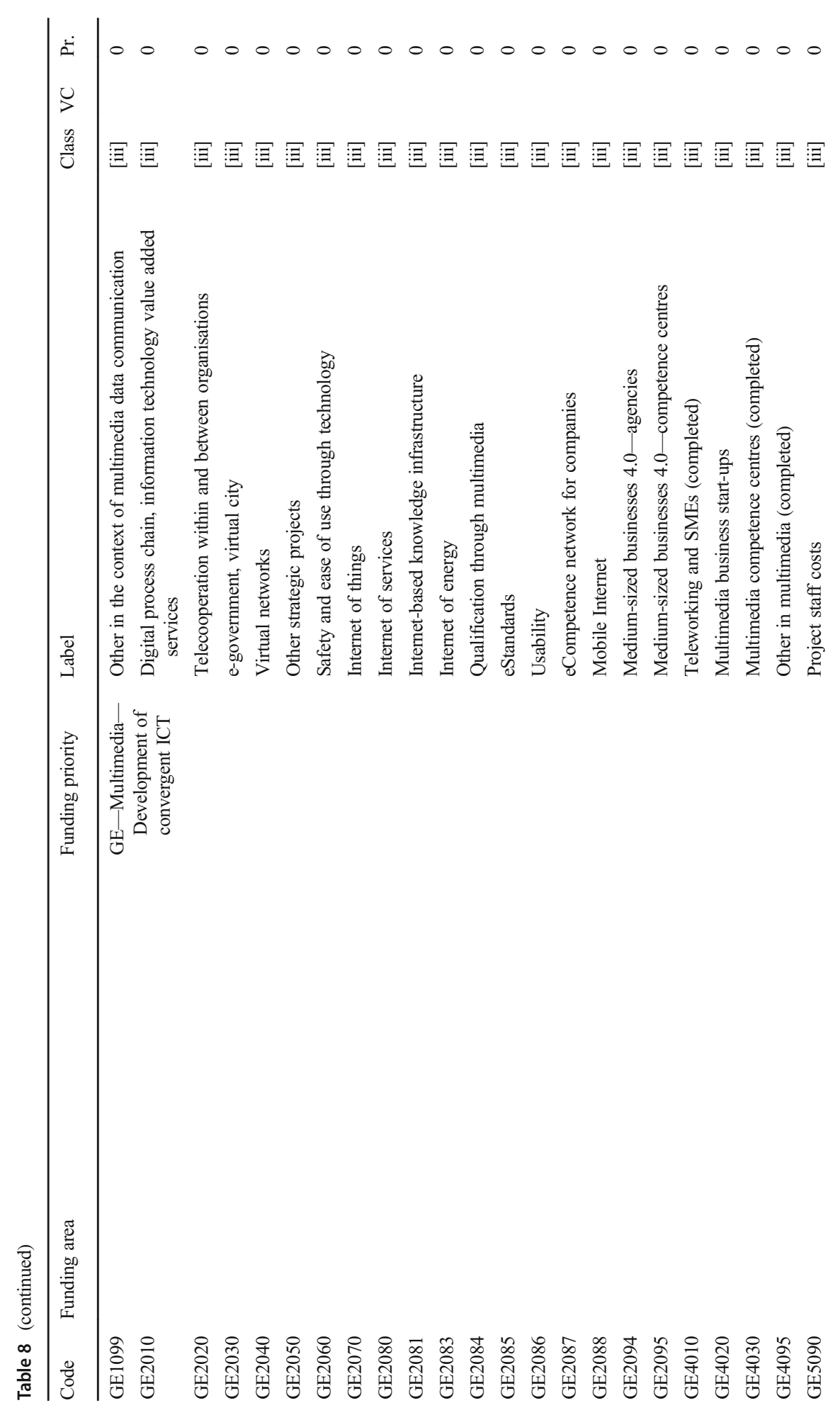




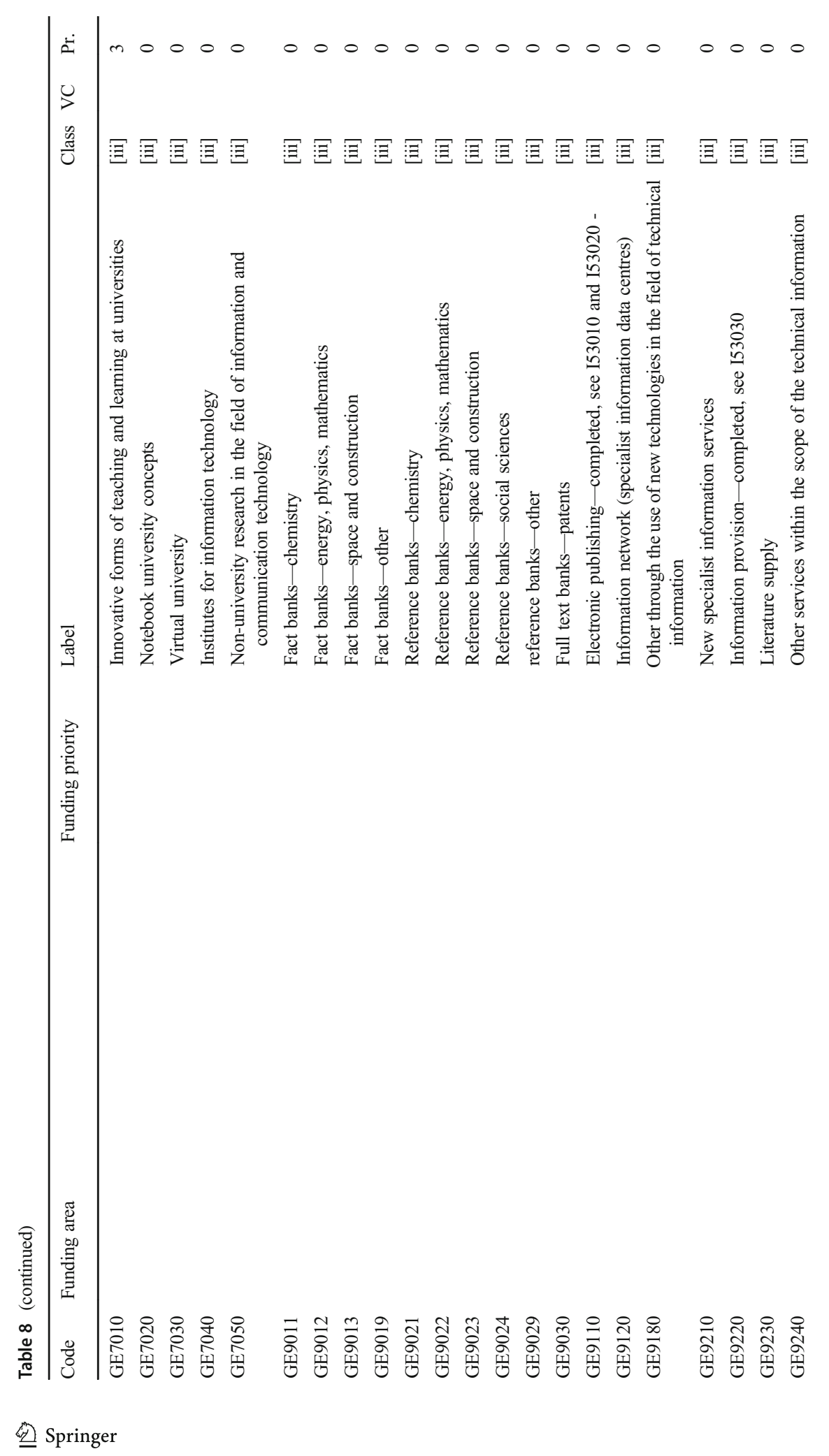




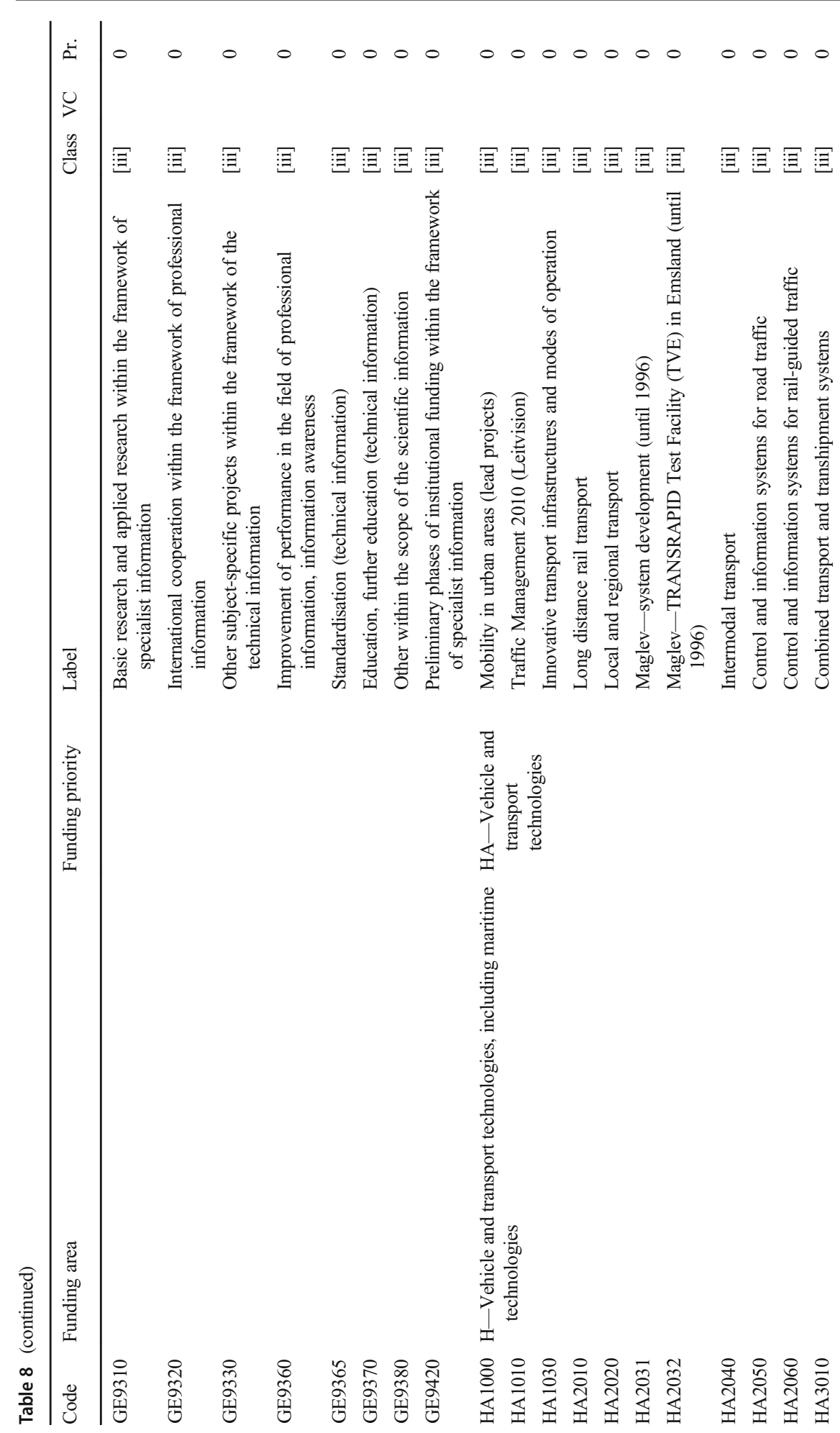




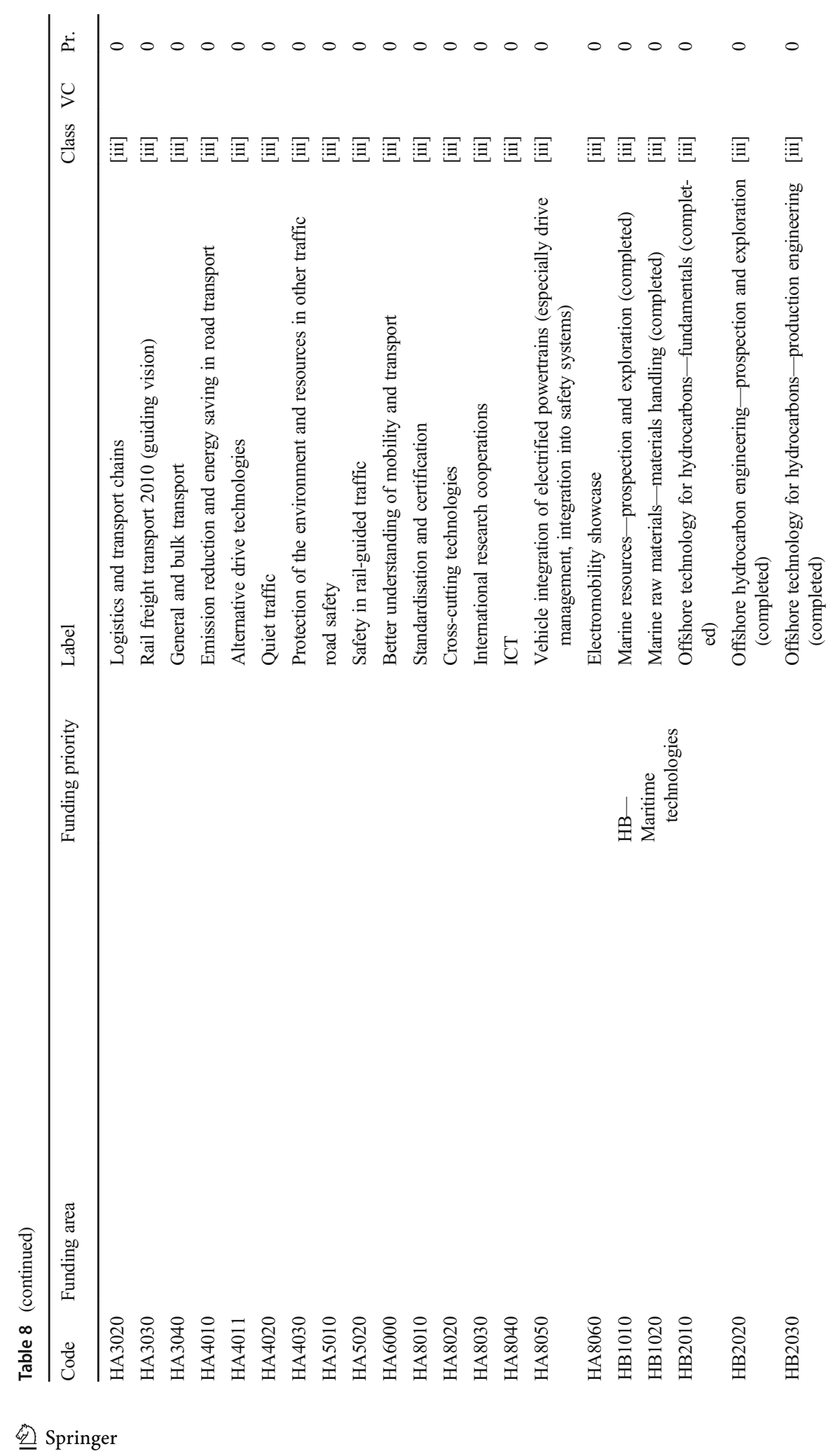




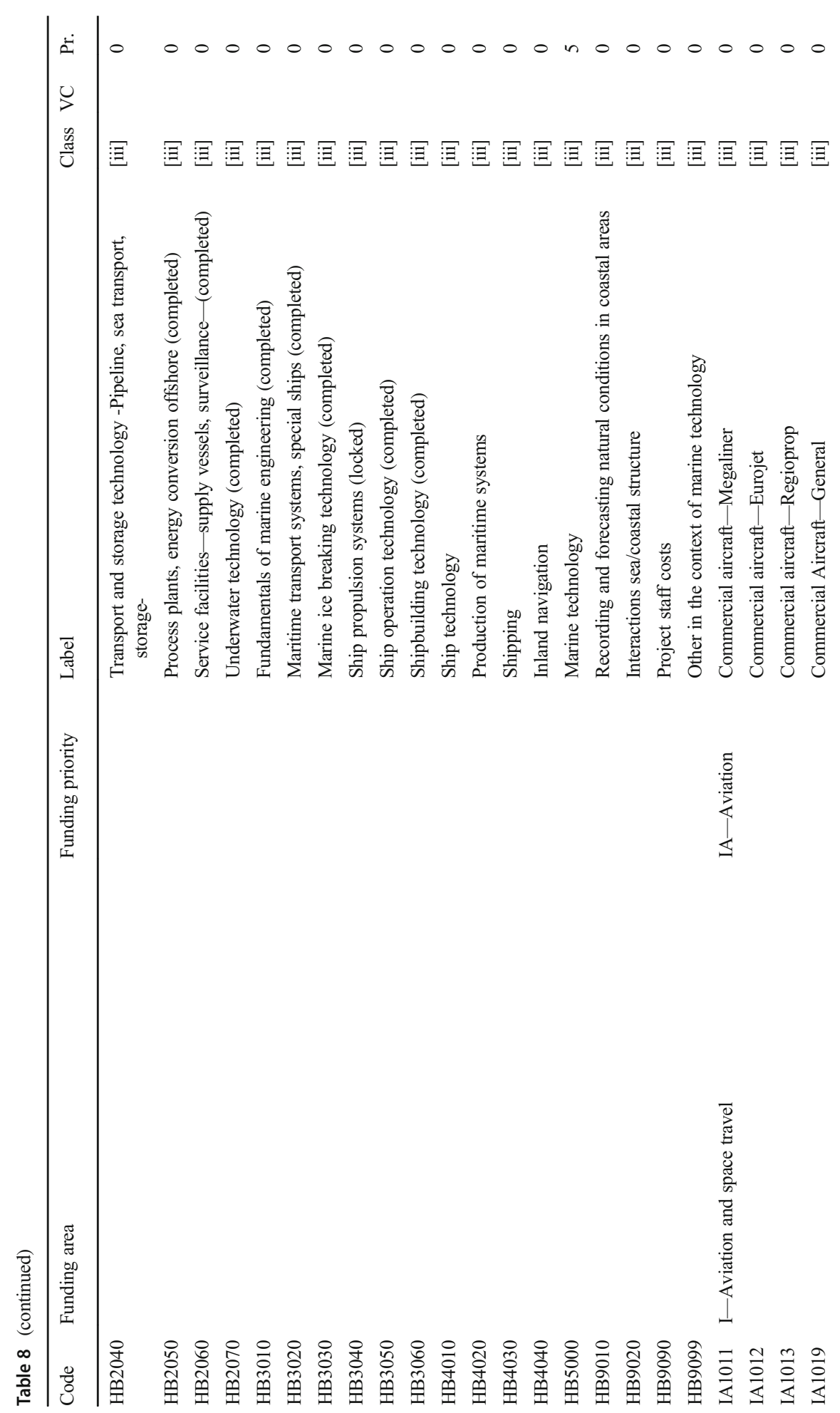




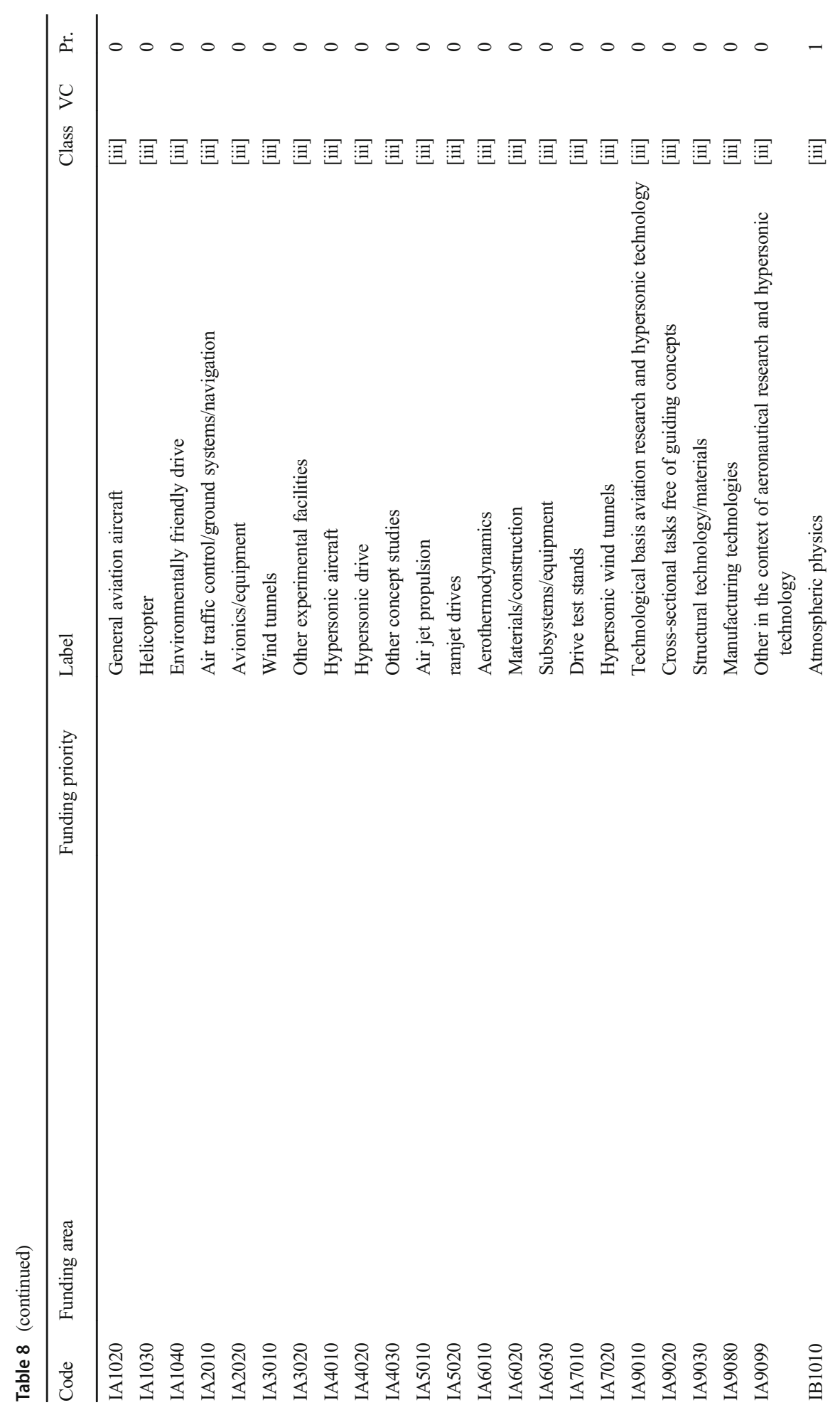




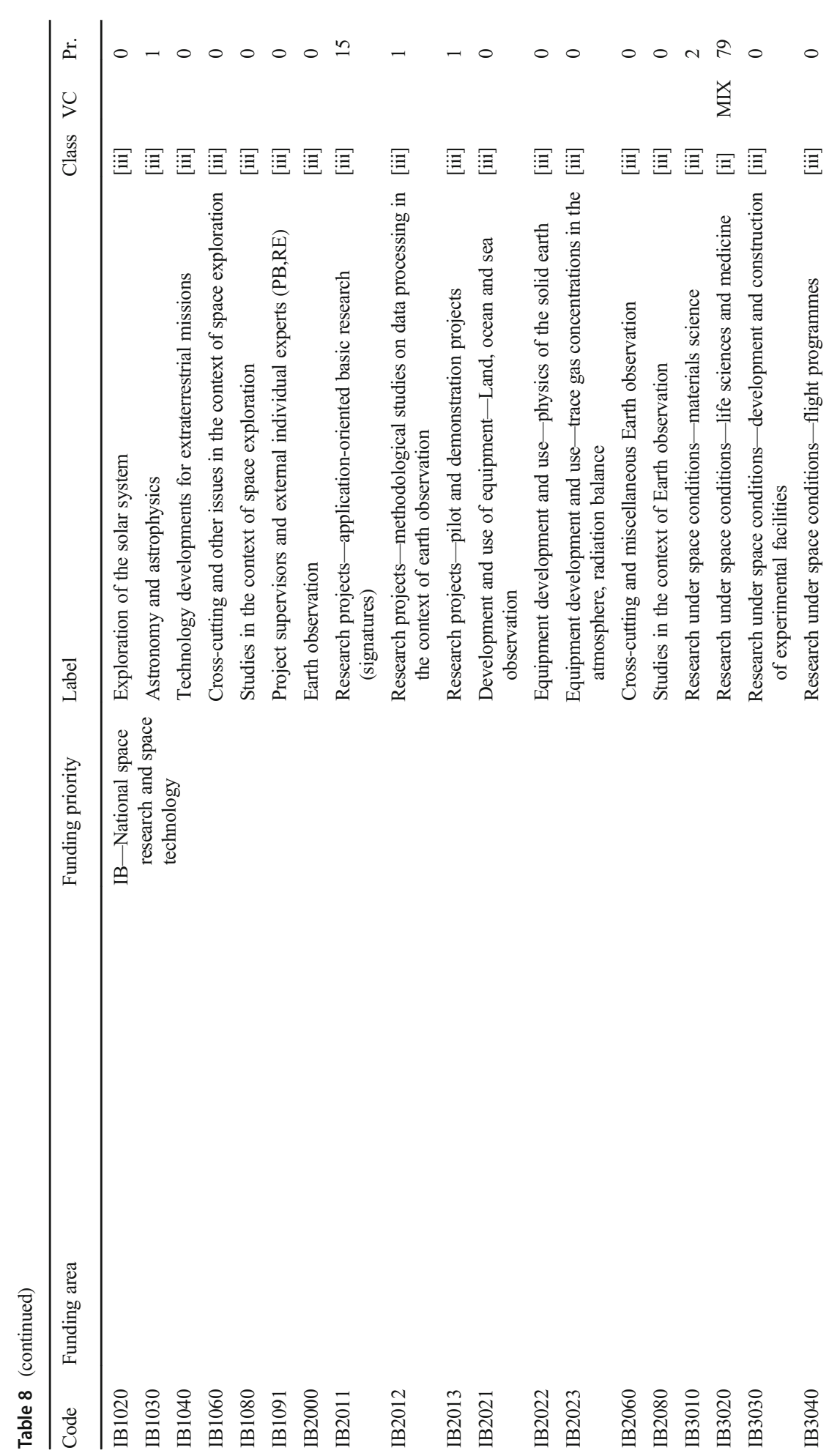




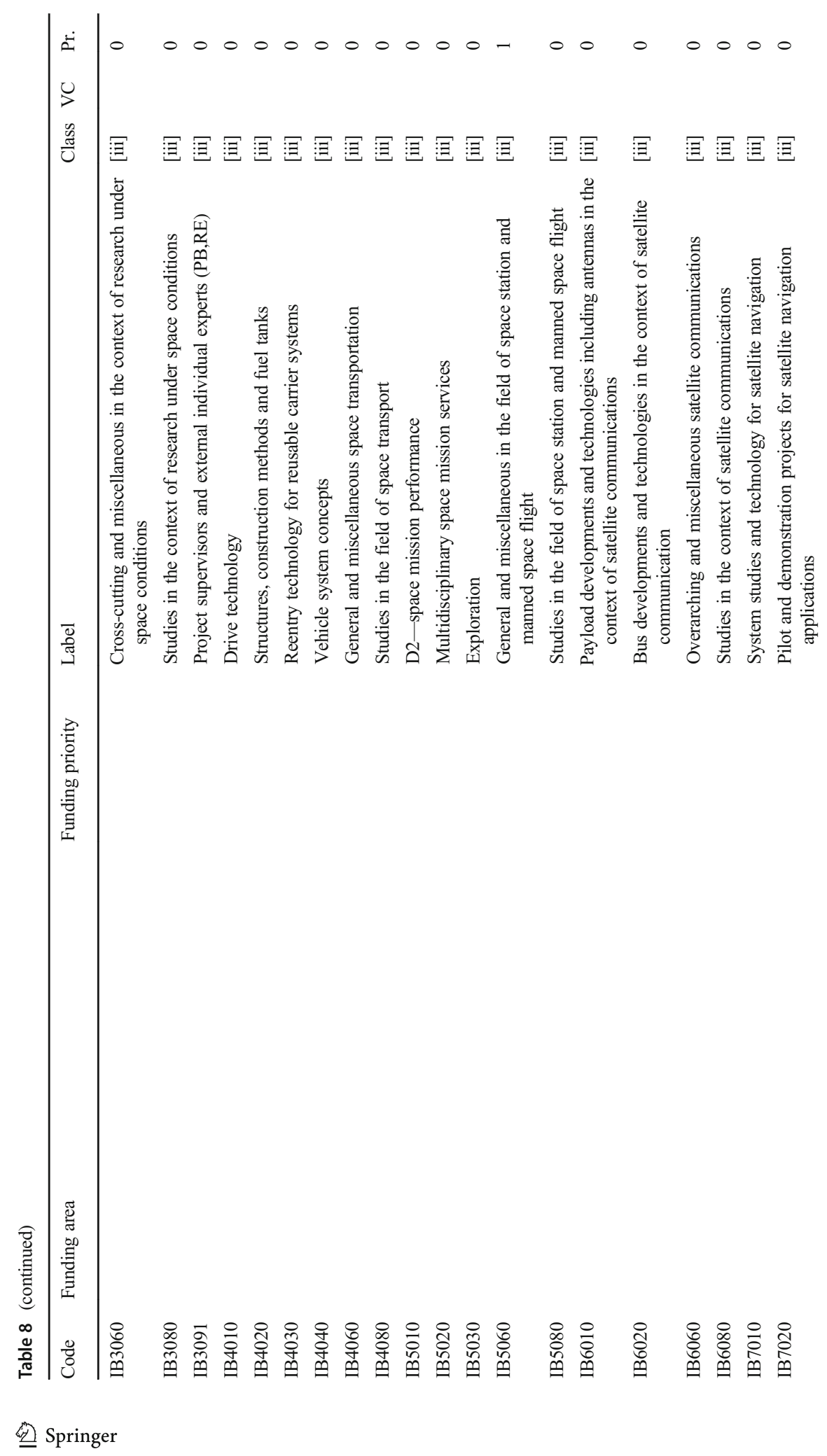




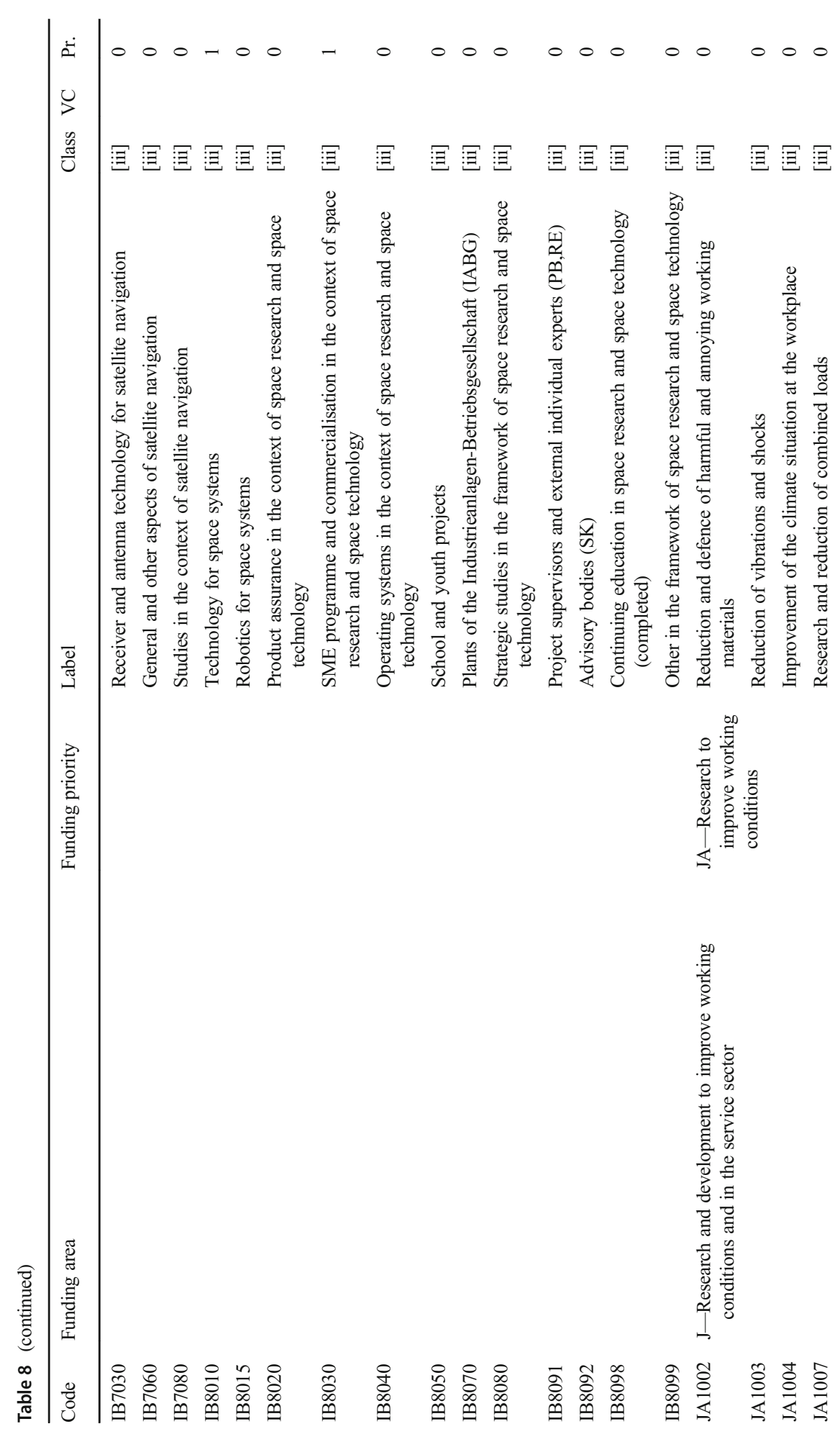




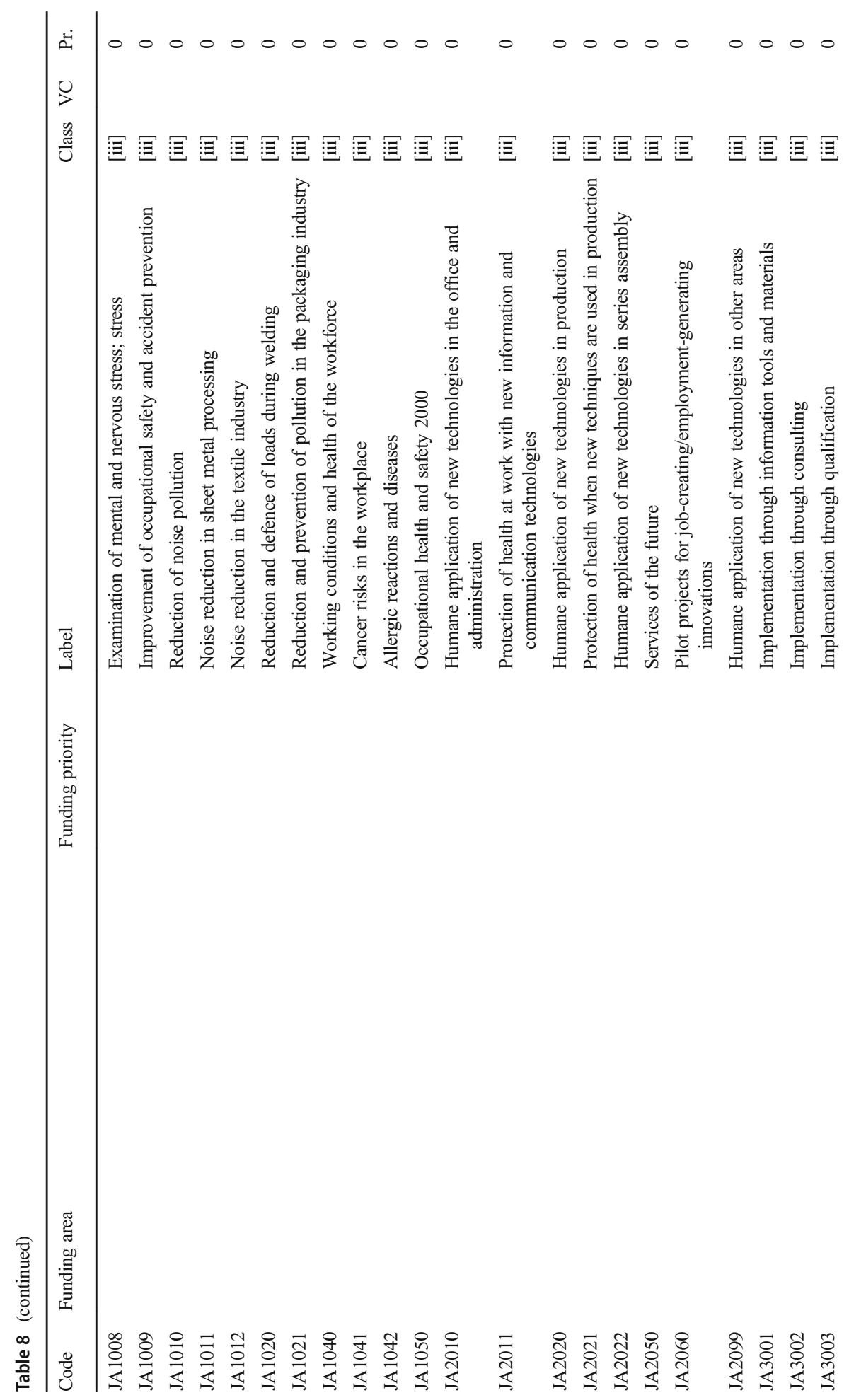




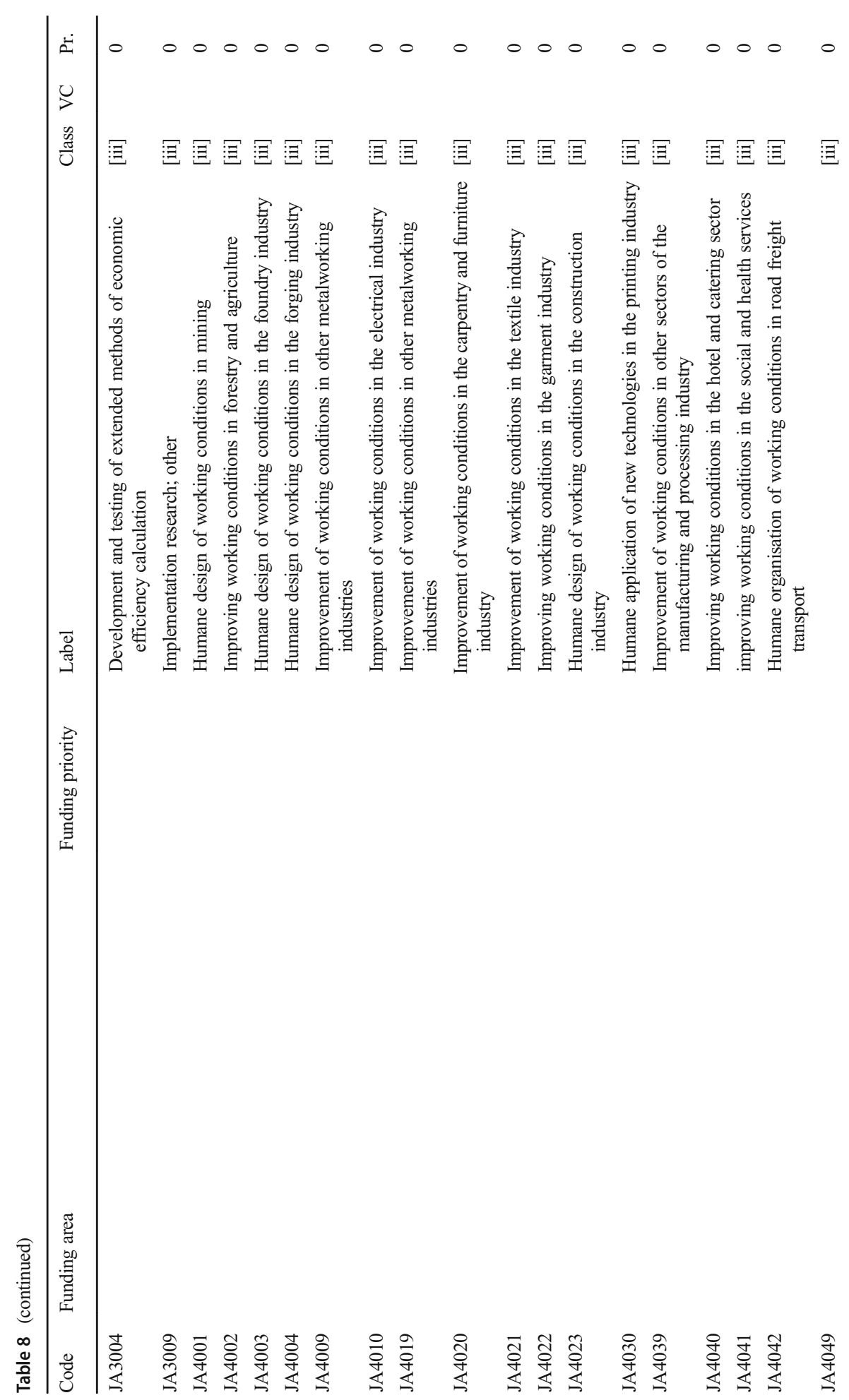




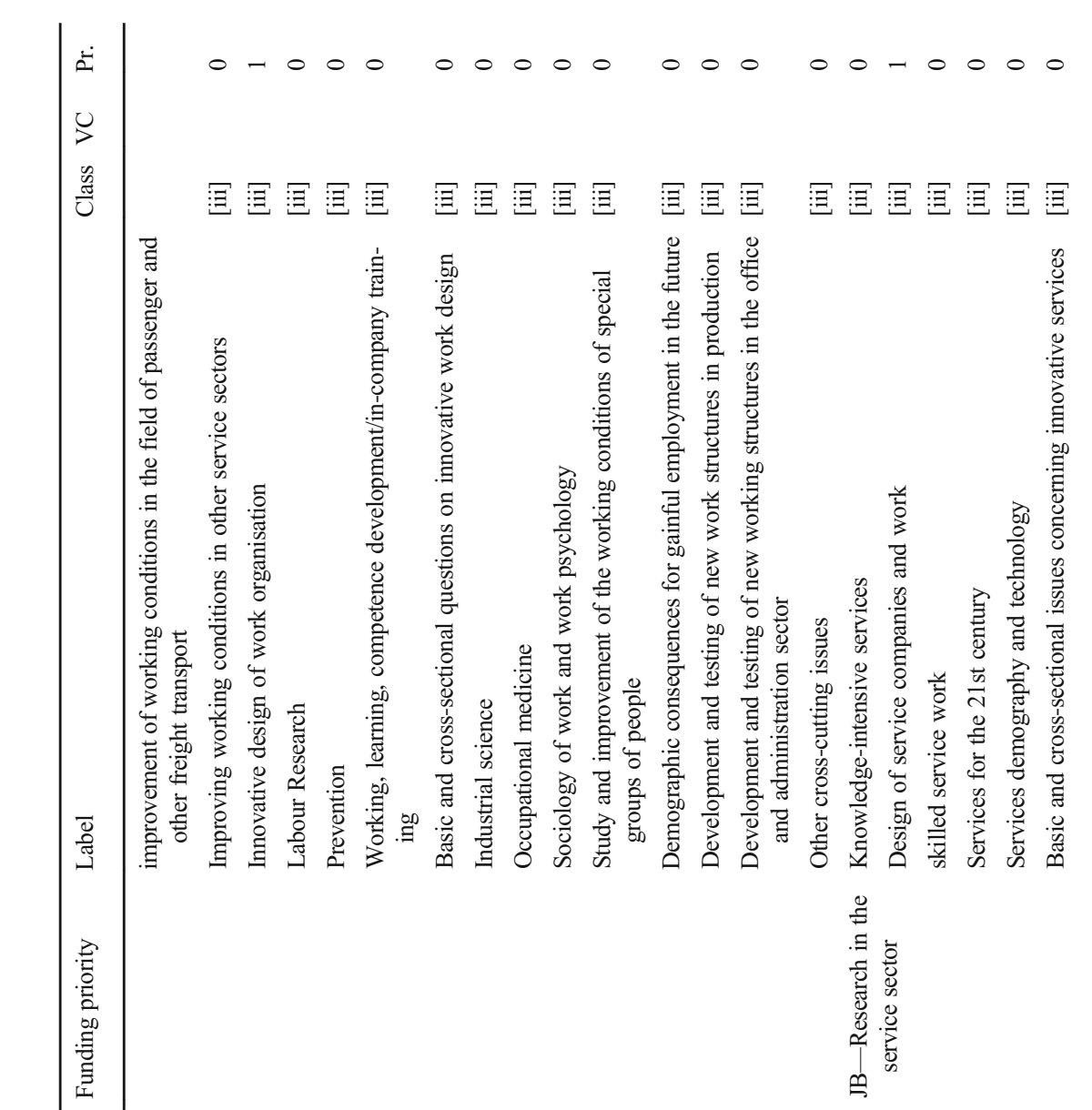




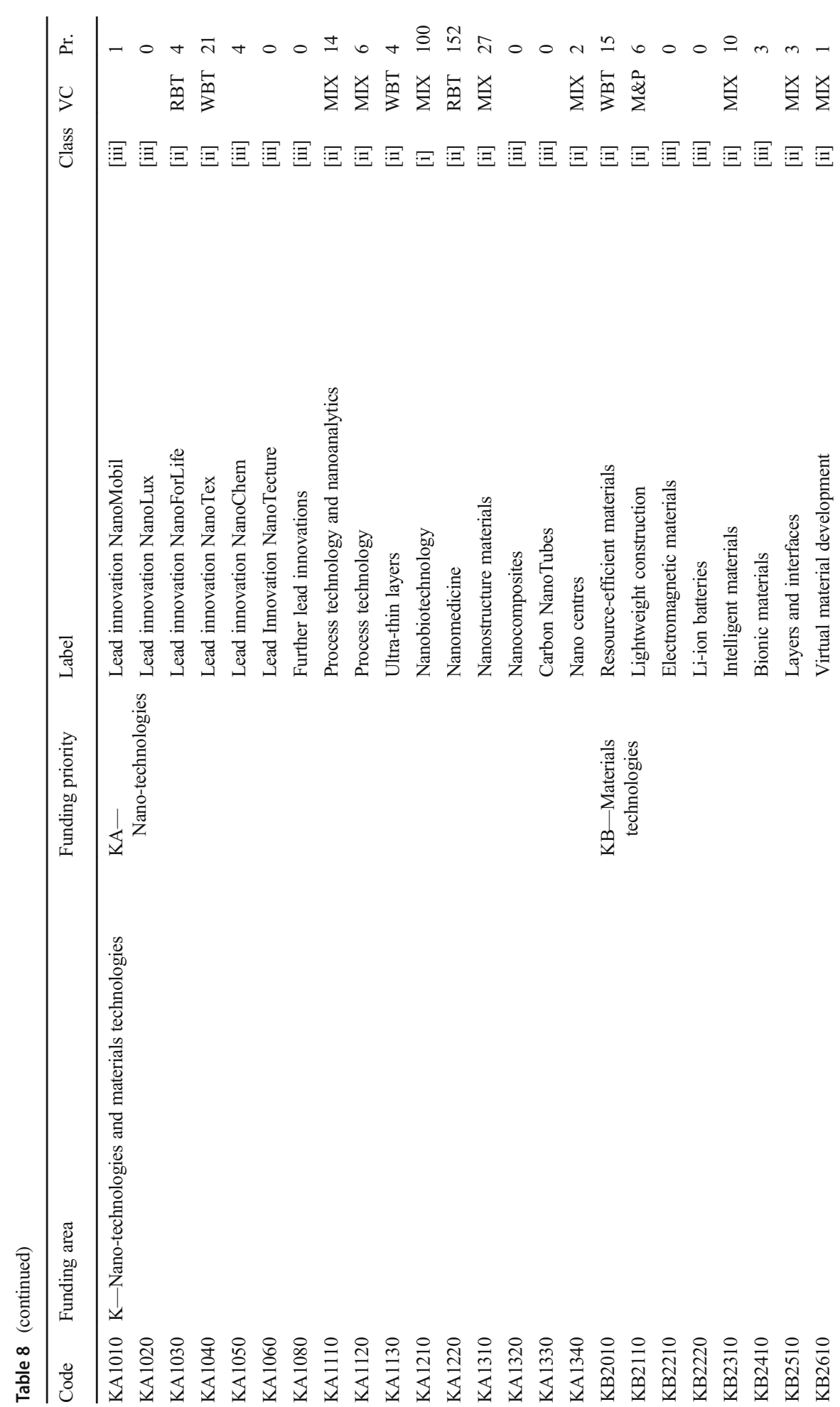




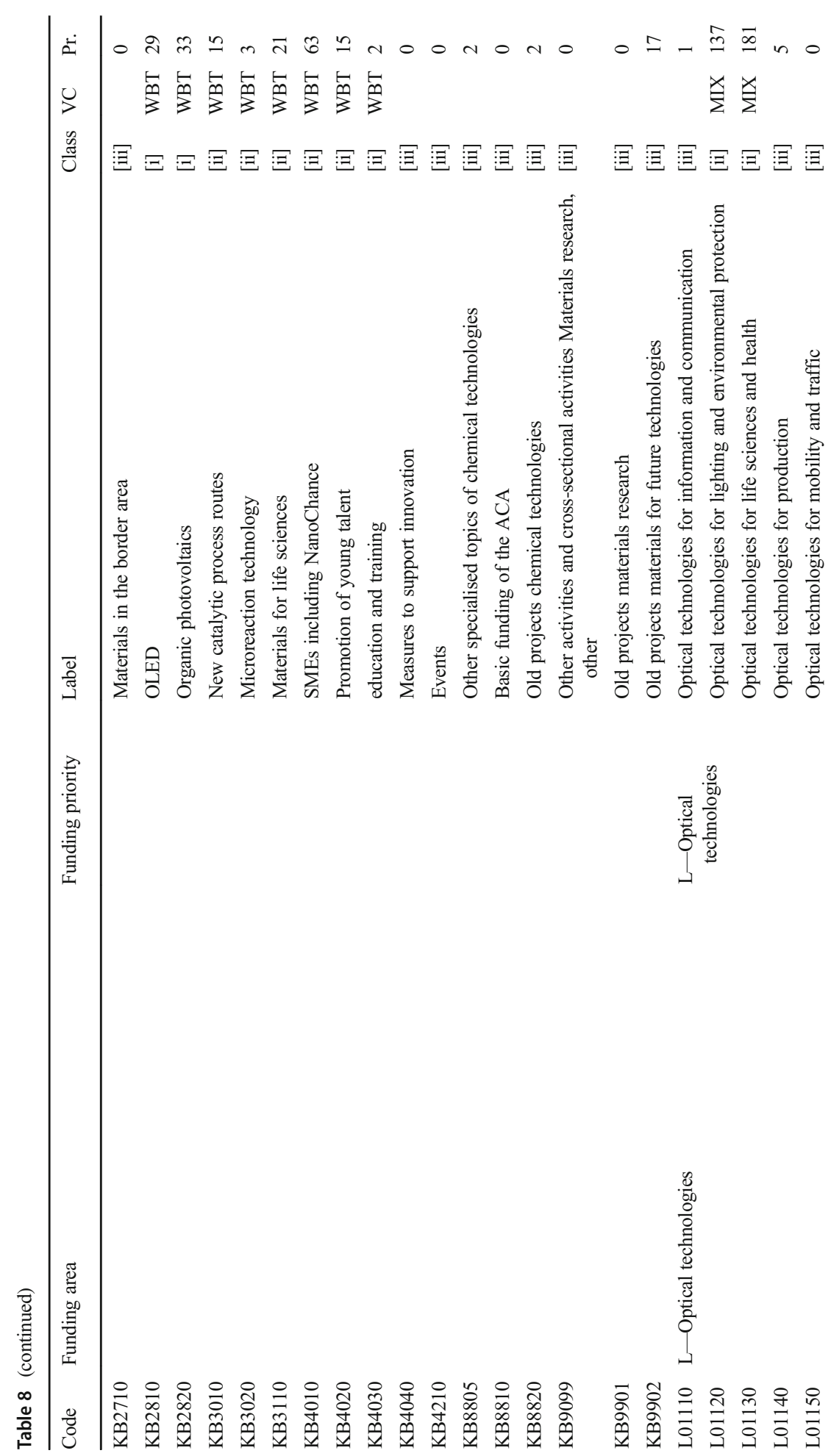




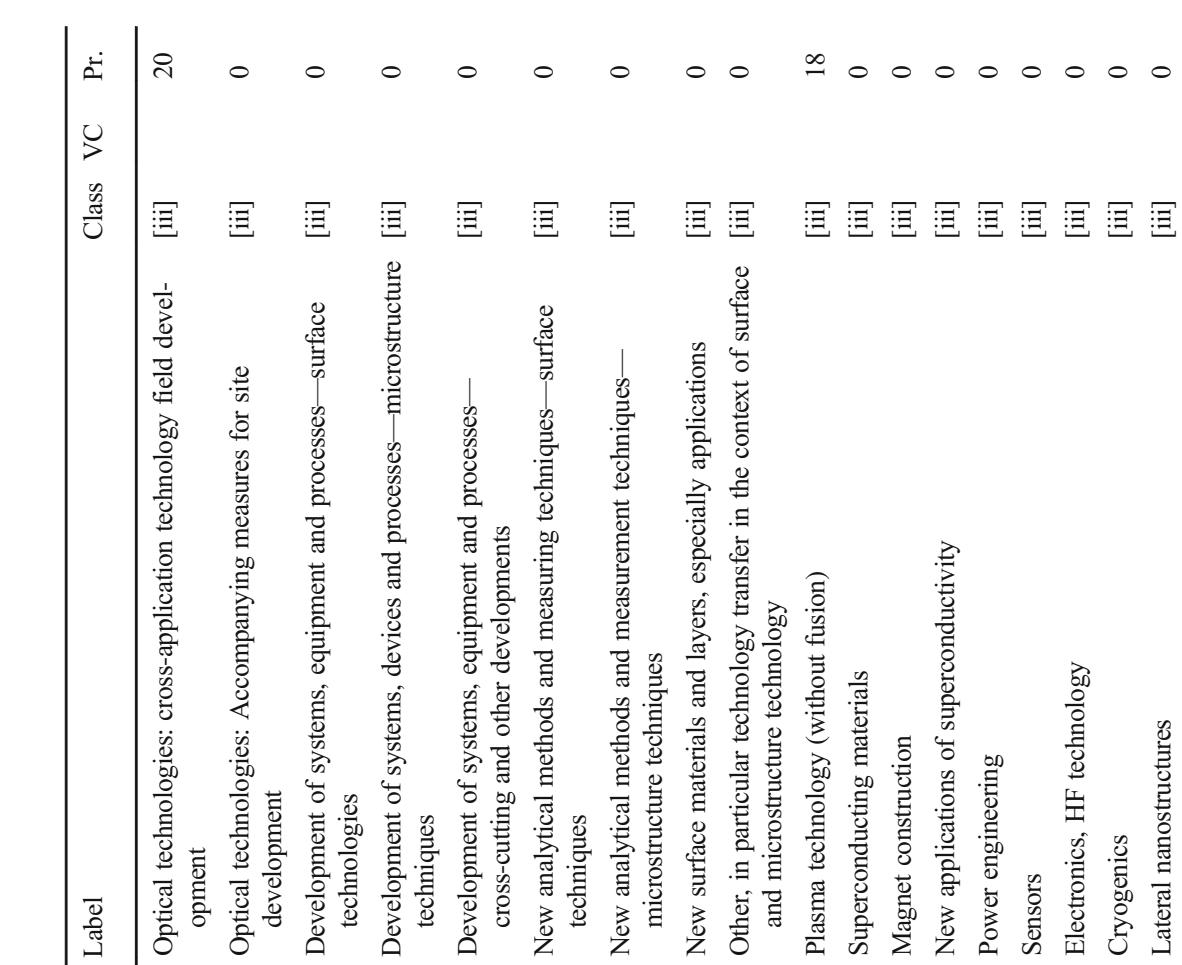




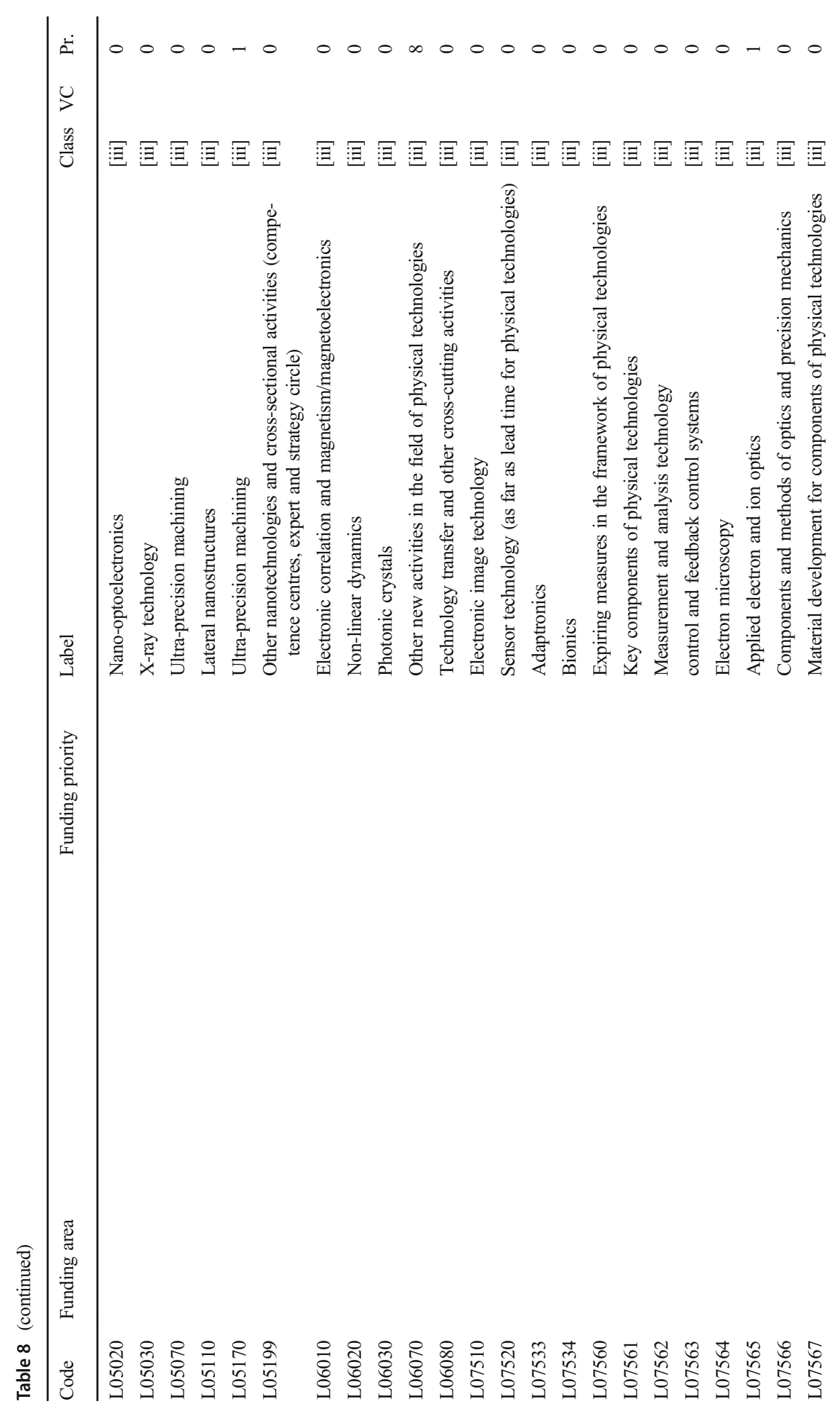




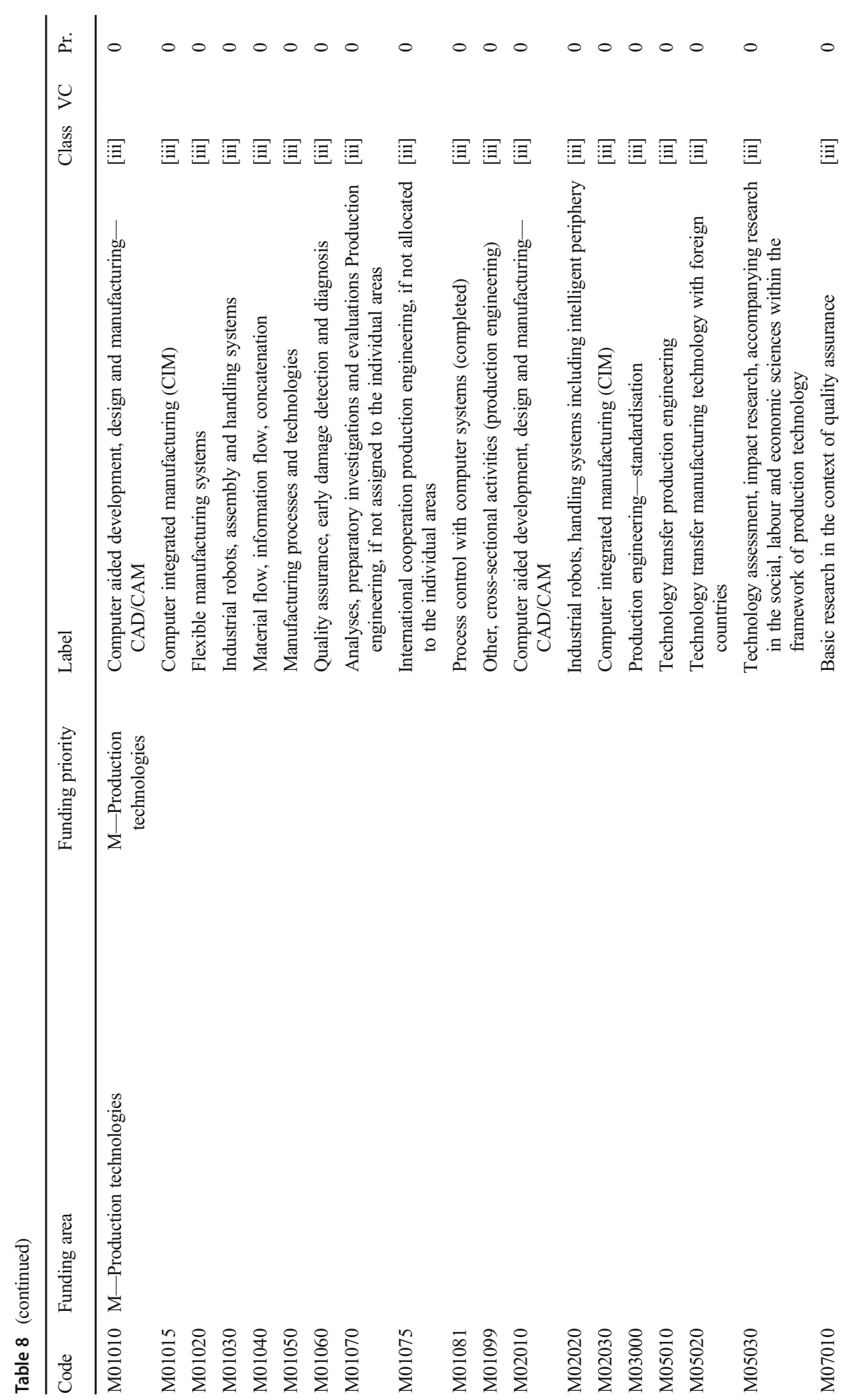




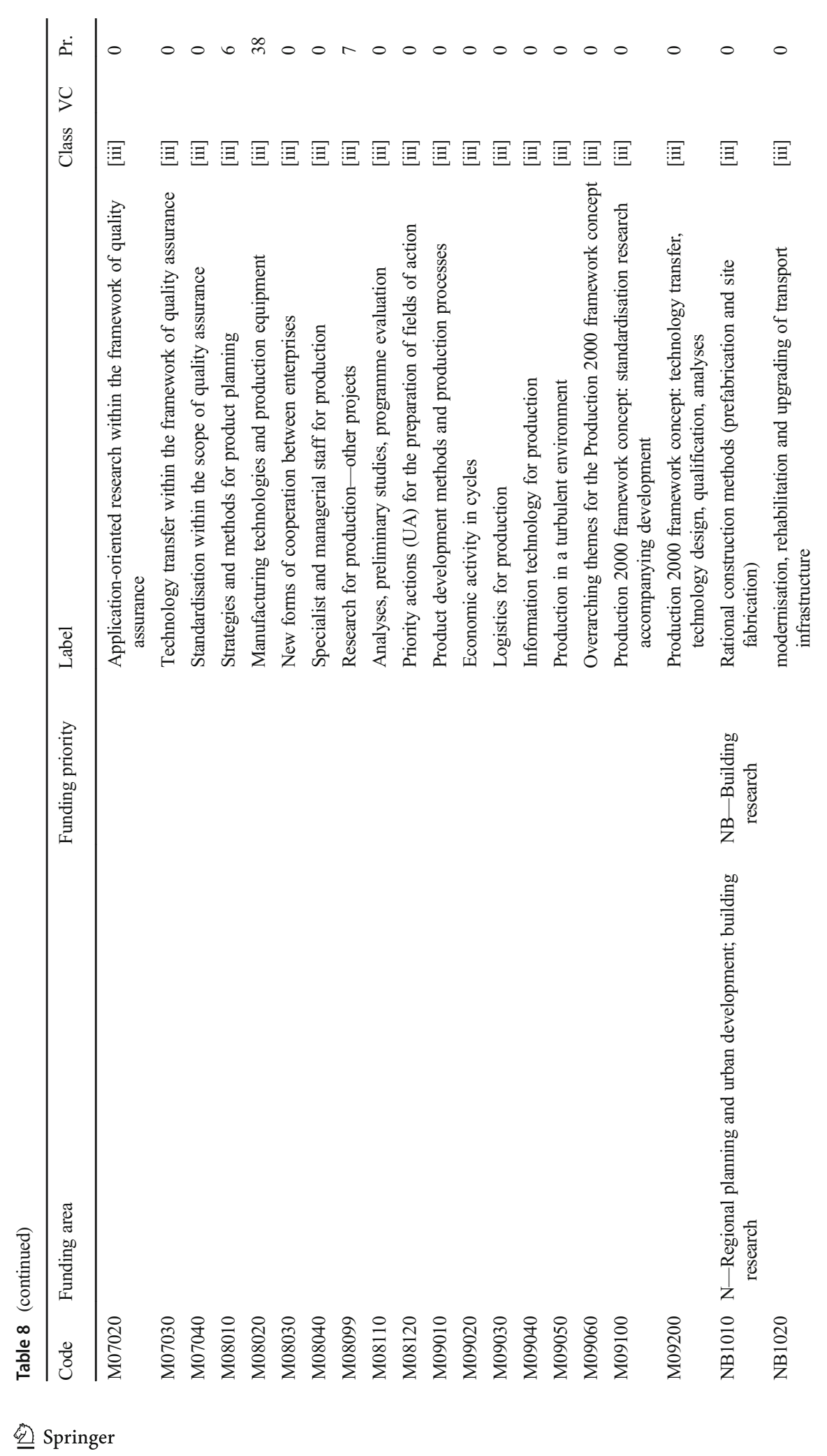




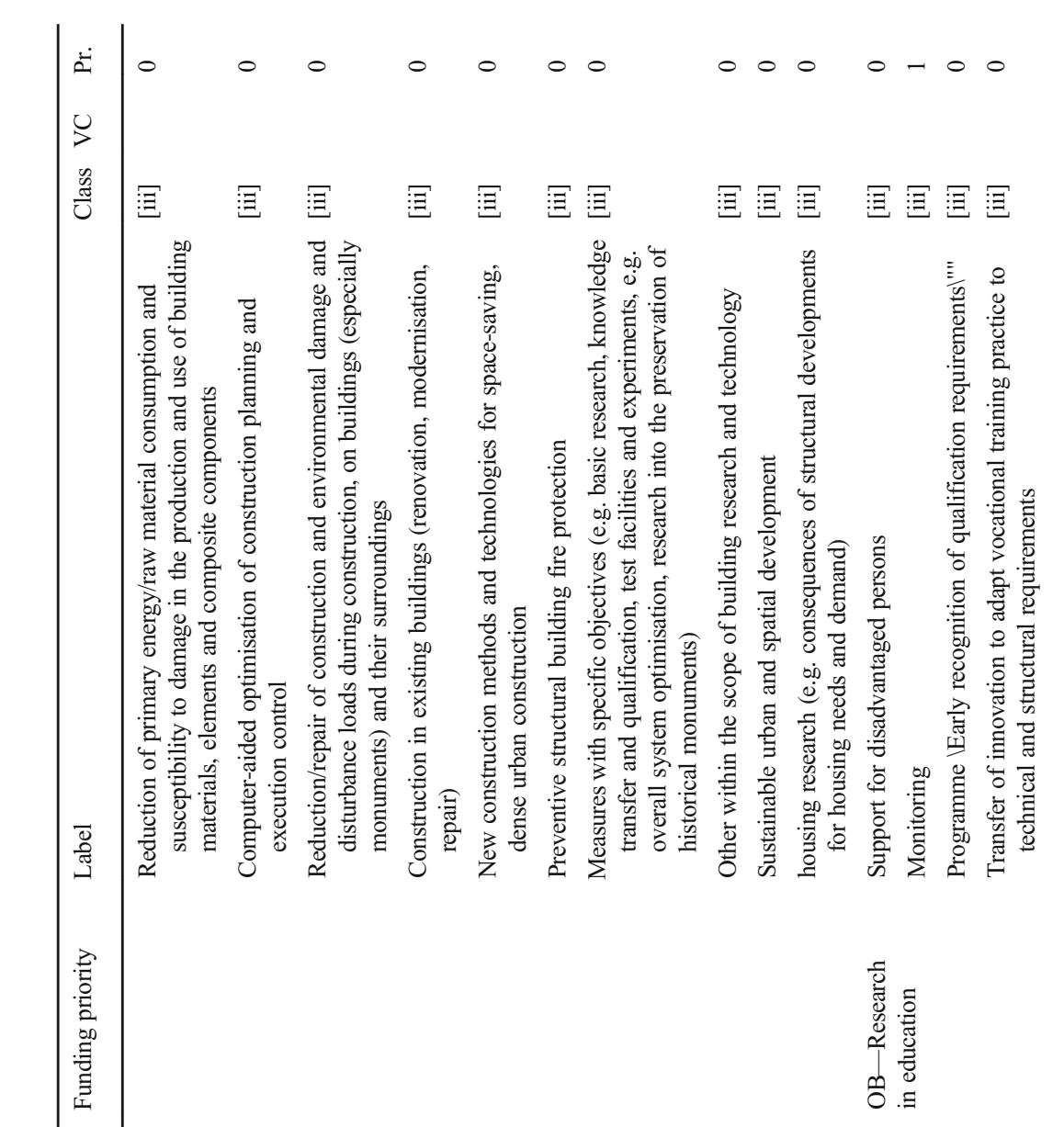

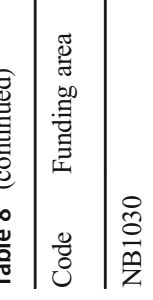
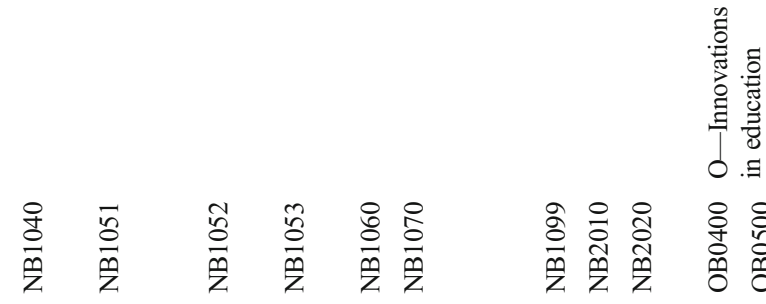


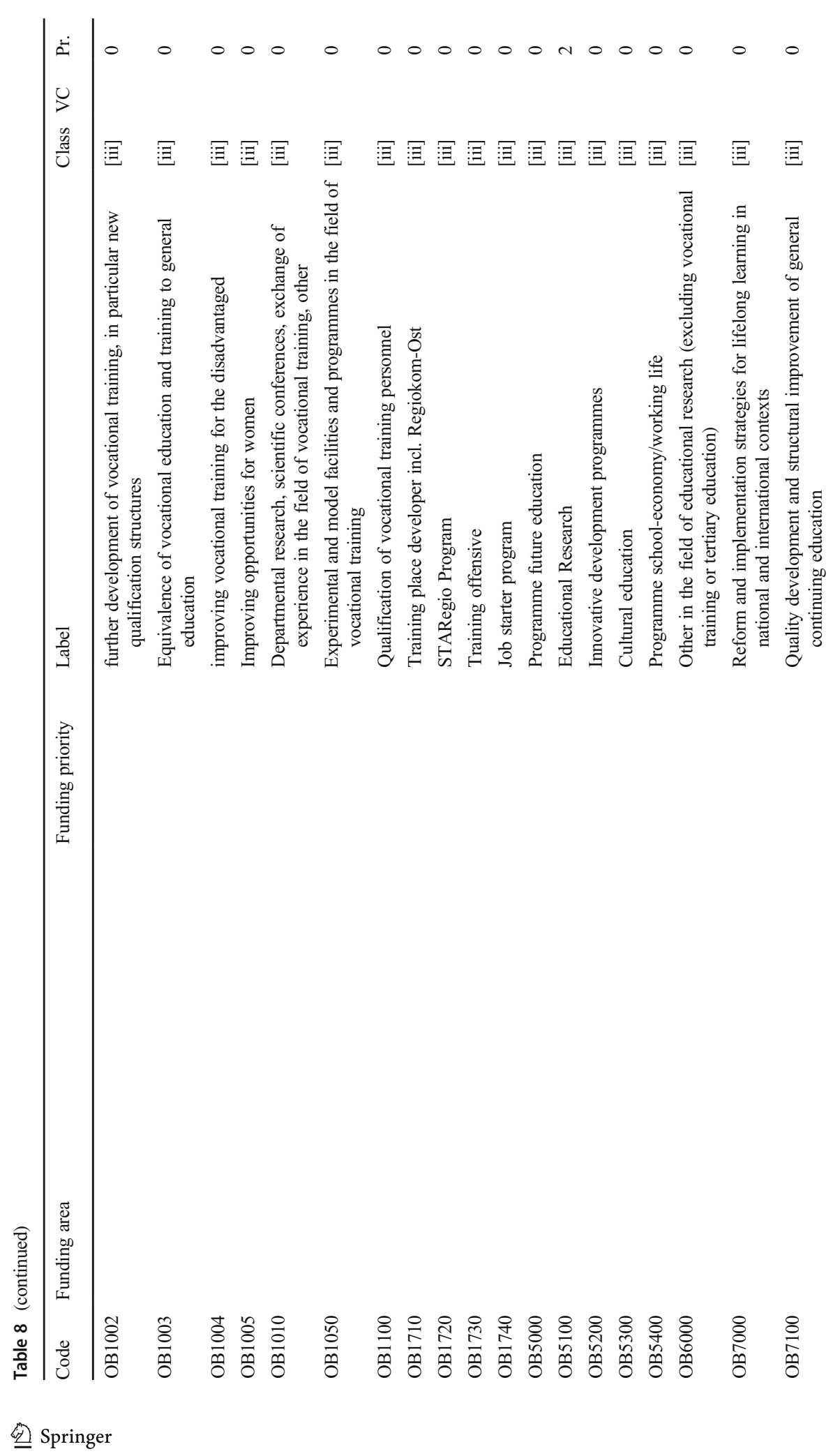




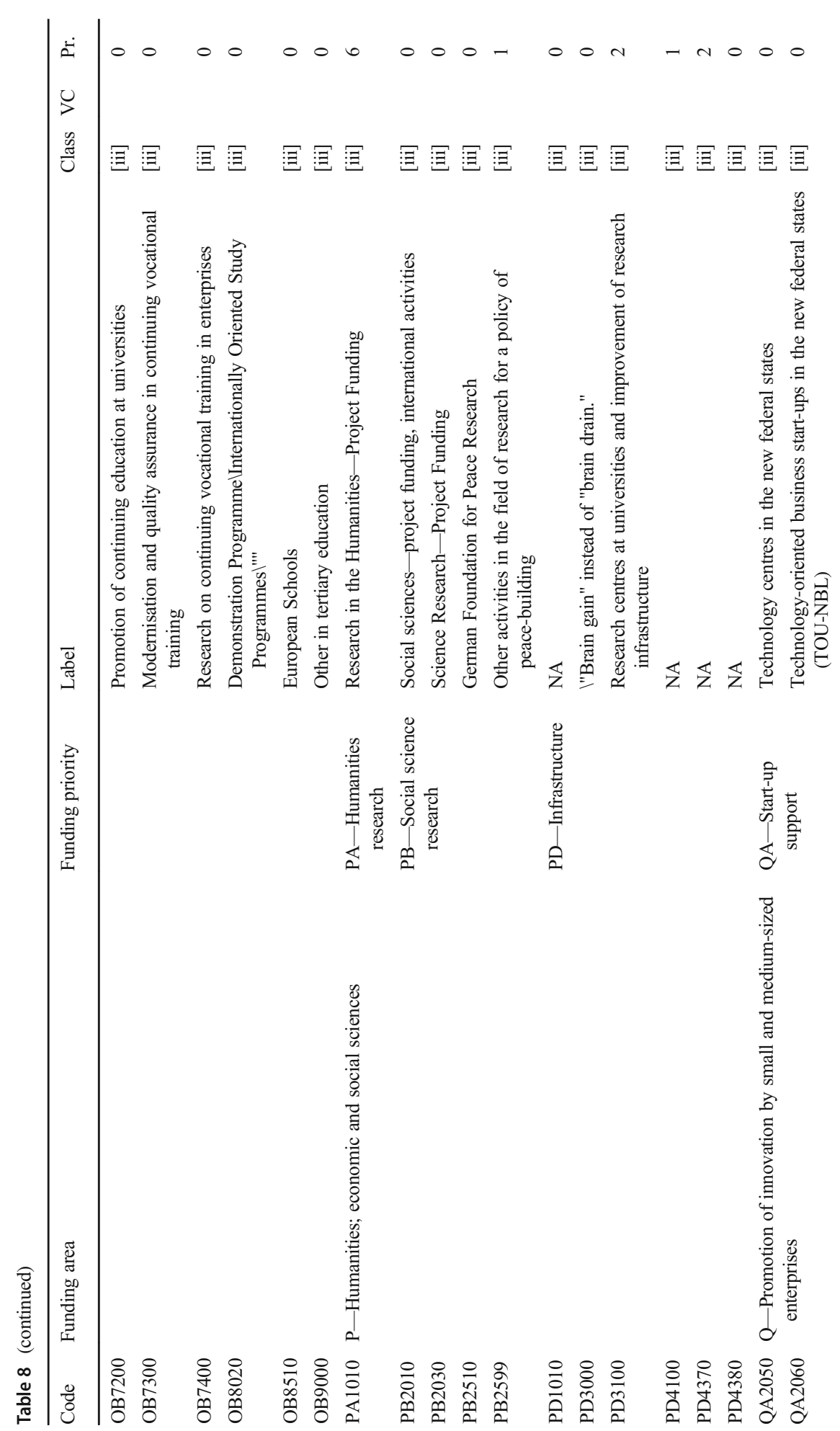




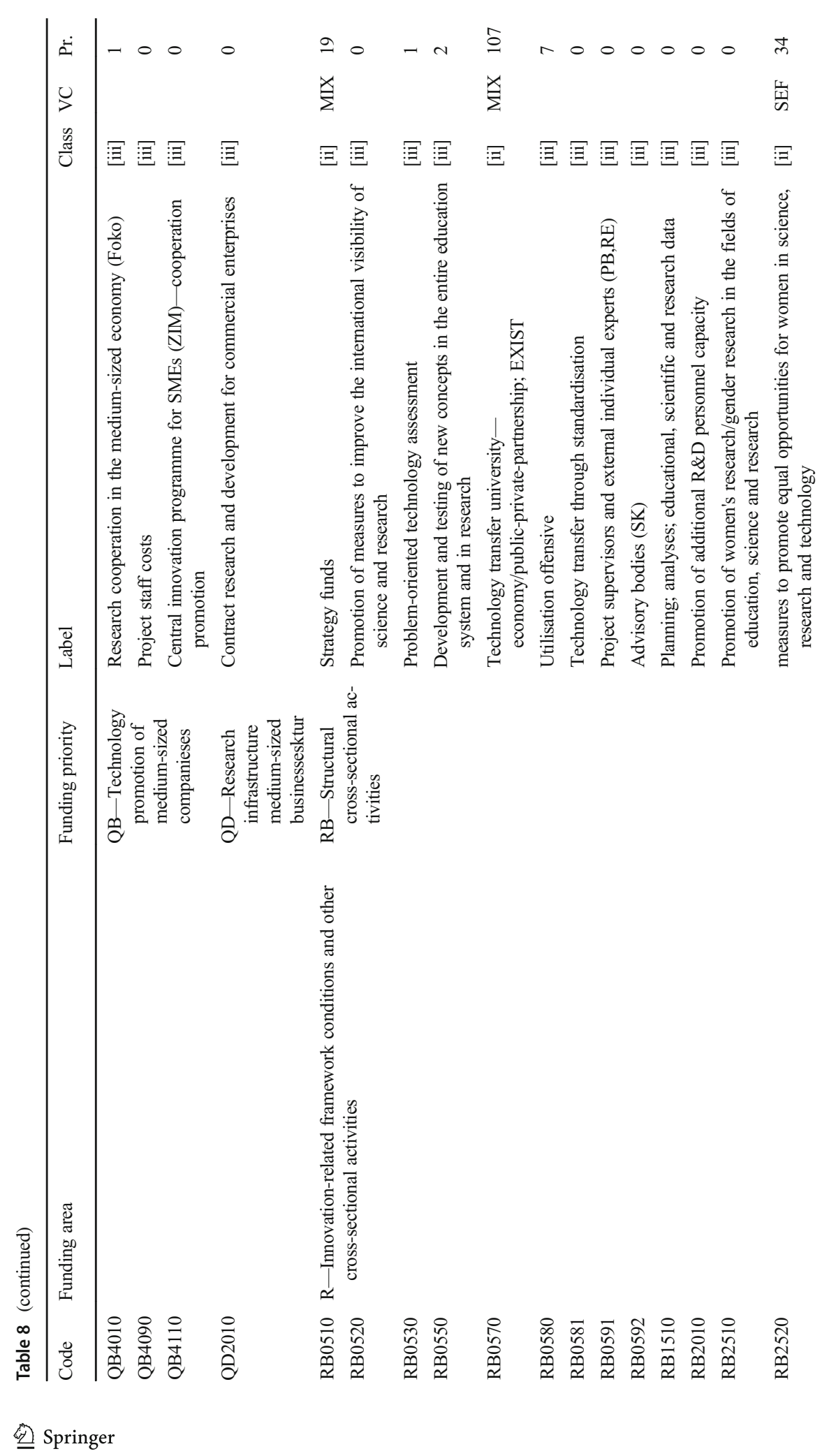



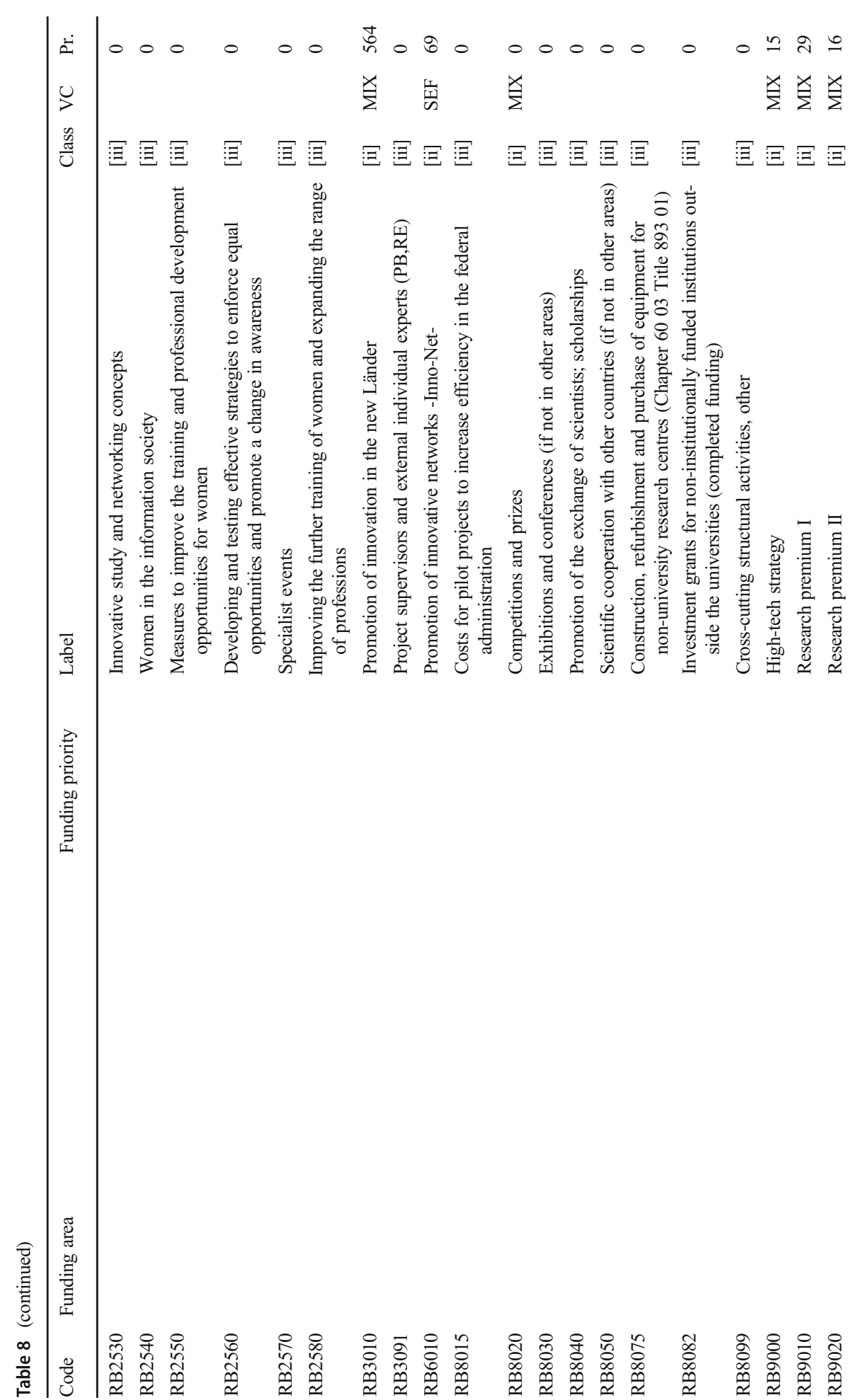

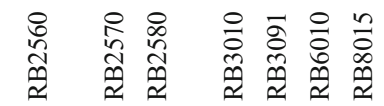




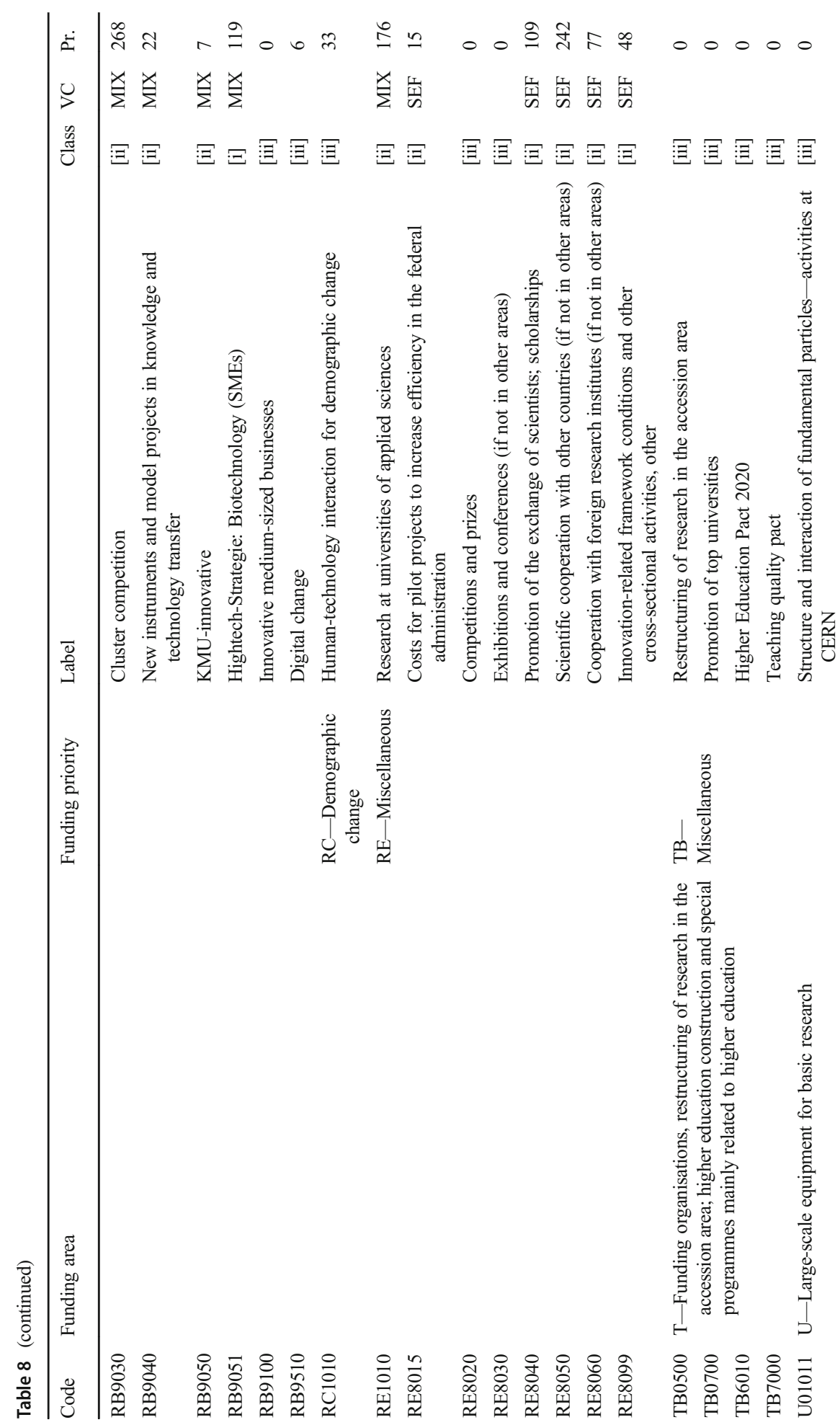




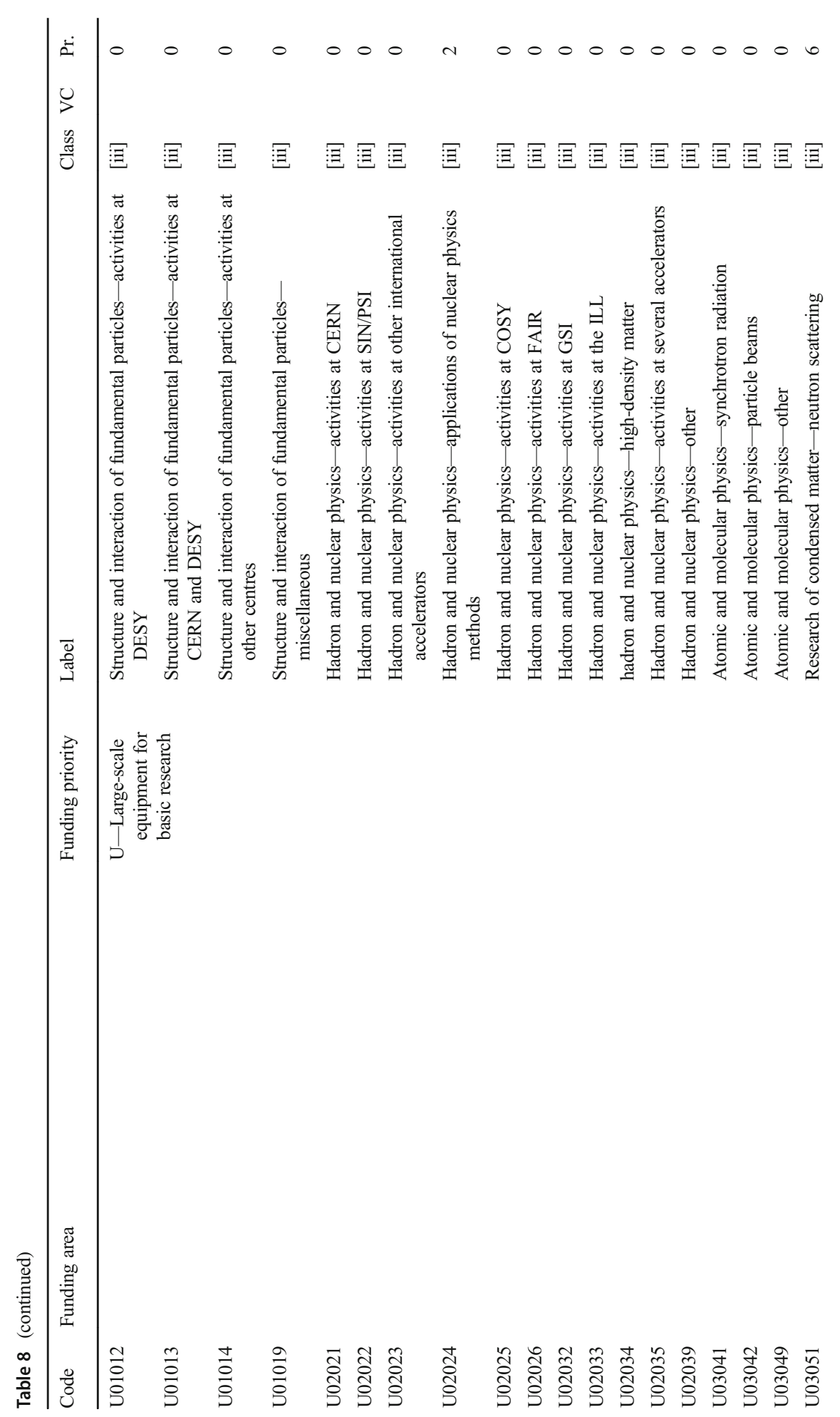




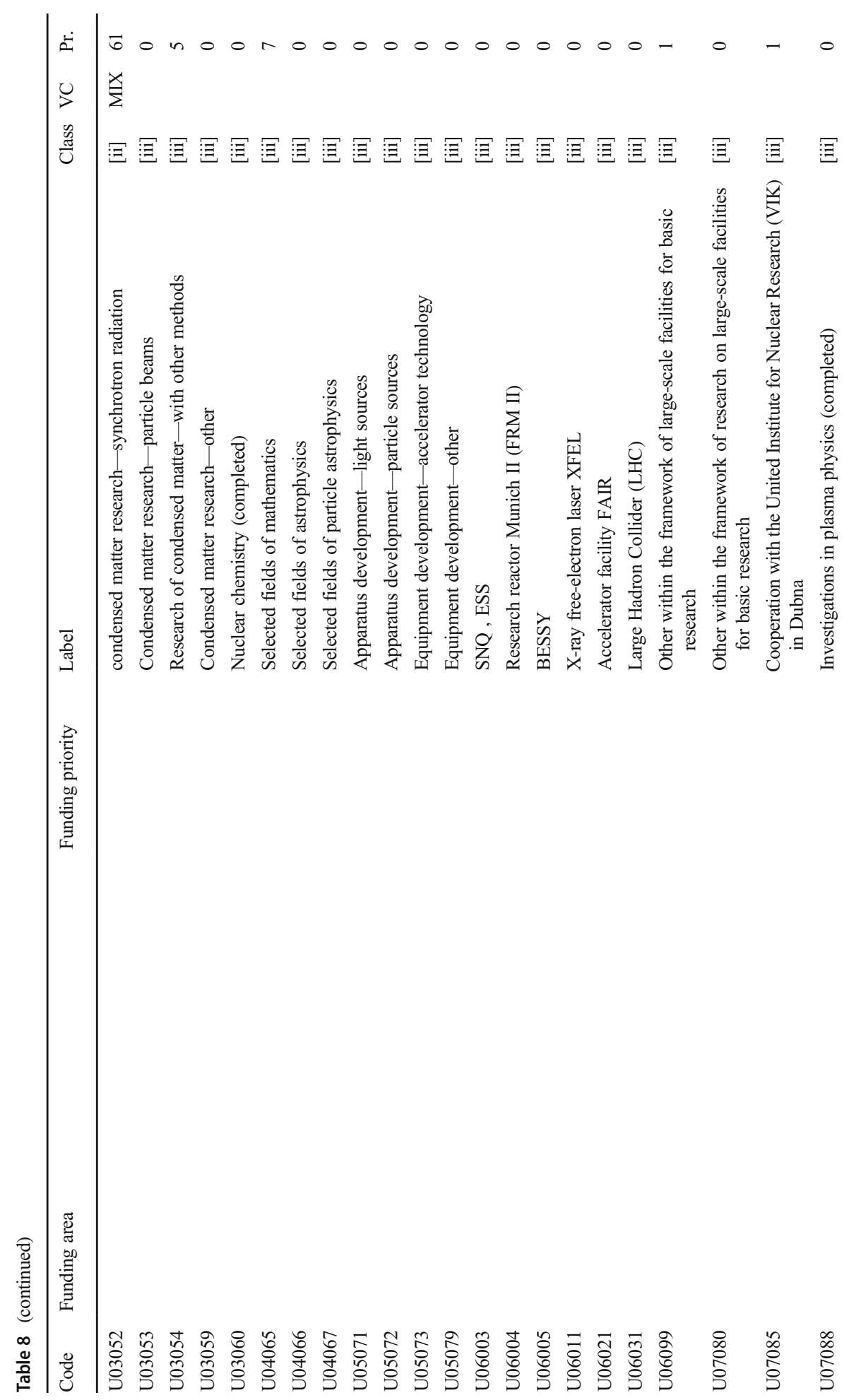




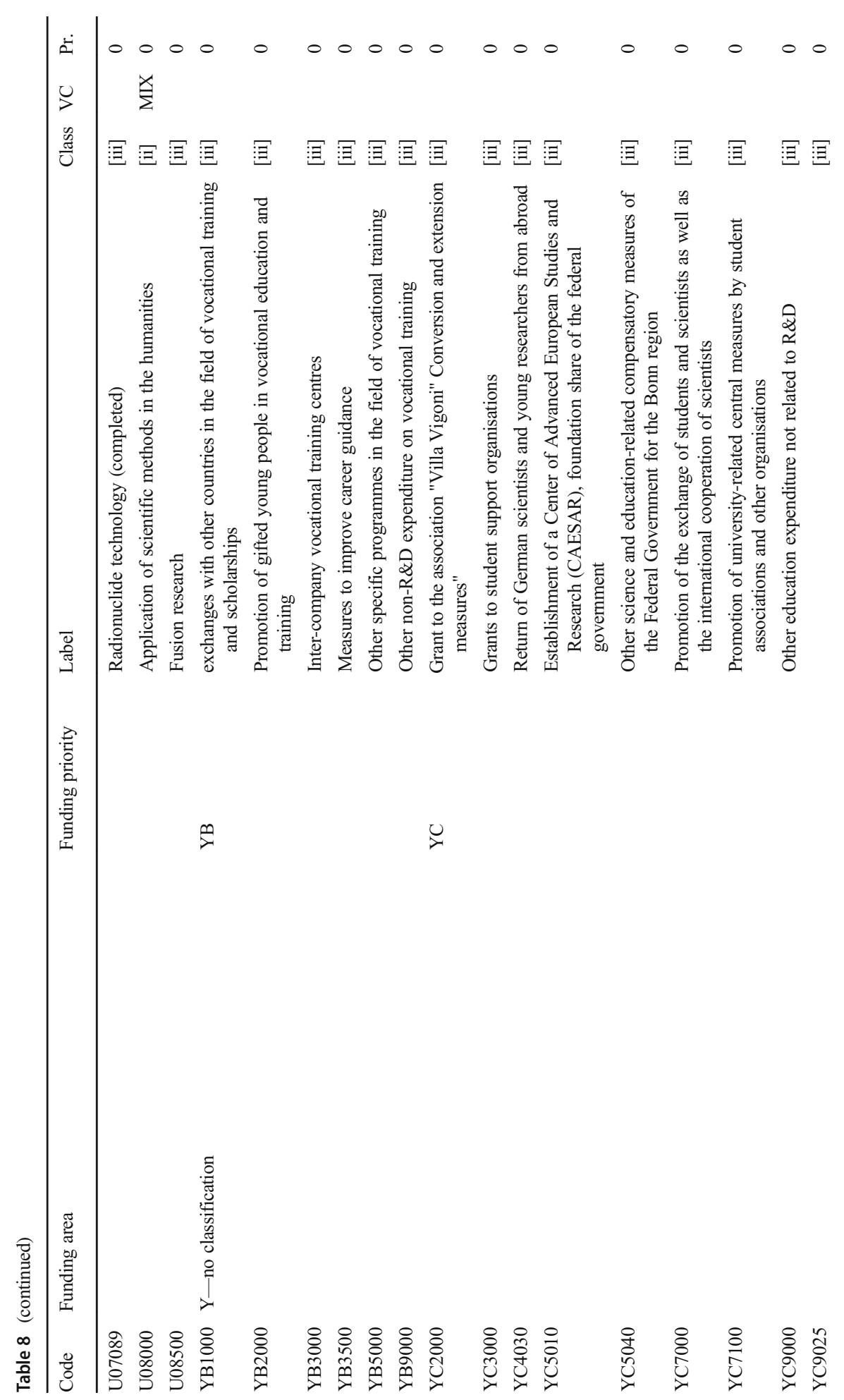




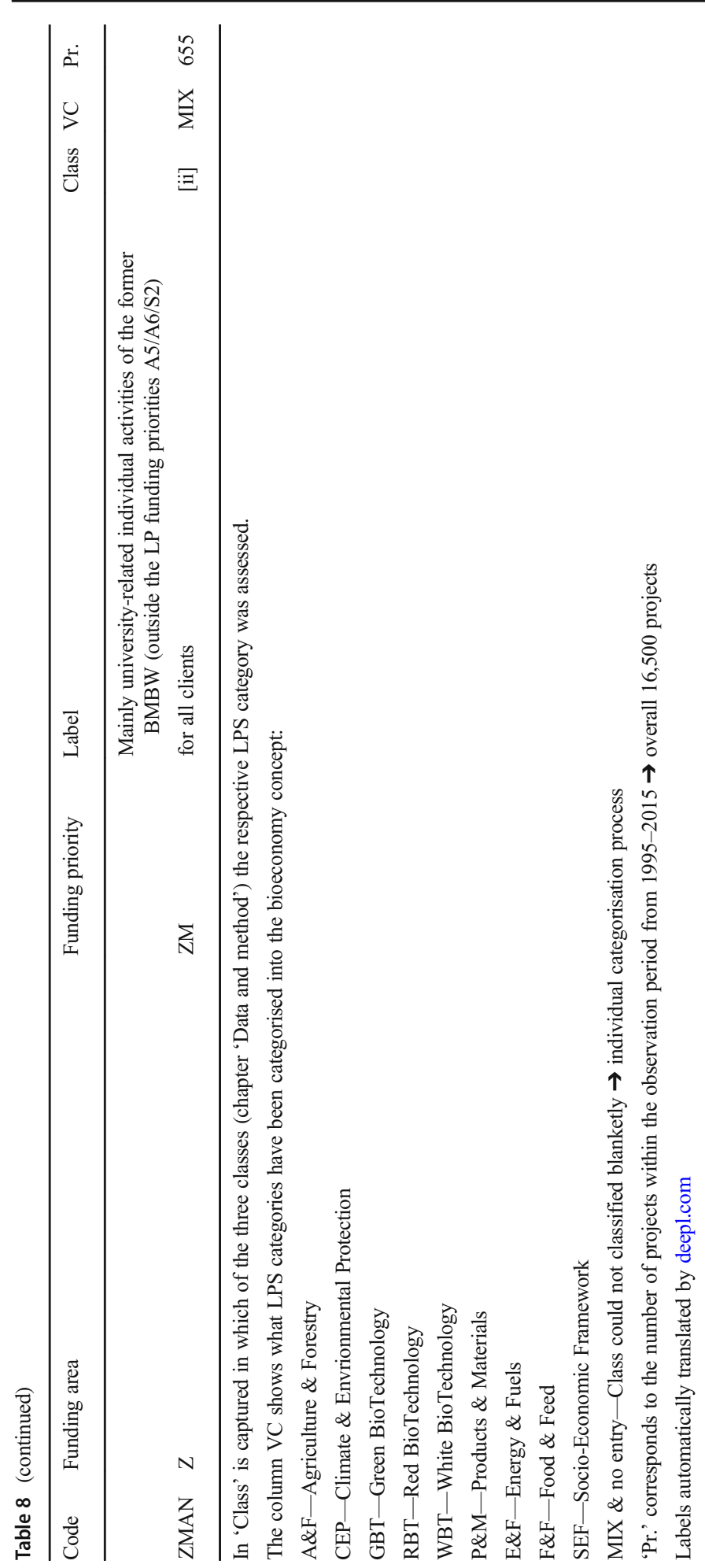


Open Access This article is licensed under a Creative Commons Attribution 4.0 International License, which permits use, sharing, adaptation, distribution and reproduction in any medium or format, as long as you give appropriate credit to the original author(s) and the source, provide a link to the Creative Commons licence, and indicate if changes were made. The images or other third party material in this article are included in the article's Creative Commons licence, unless indicated otherwise in a credit line to the material. If material is not included in the article's Creative Commons licence and your intended use is not permitted by statutory regulation or exceeds the permitted use, you will need to obtain permission directly from the copyright holder. To view a copy of this licence, visit http://creativecommons.org/licenses/by/4.0/.

\section{References}

Aghion P, David PA, Foray D (2009) Science, technology and innovation for economic growth - Linking policy research and practice in 'STIG Systems'. Research Policy 38(4):681-693. https://doi.org/10.1016/j. respol.2009.01.016

Aguilar A, Bochereau L, Matthiessen L (2009) Biotechnology as the engine for the Knowledge-Based BioEconomy. Biotechnology and Genetic Engineering Reviews 26(1):371-388. https://doi.org/10.5661/ bger-26-371

Albert S (2007) Transition to a bio-economy - A community development strategy discussion. Journal of Rural and Community Development 2(2):64-83

Bennett B (2007) Law and ethics for the bioeconomy and beyond. Journal of law and medicine 15(1):7-13

Biggi G, Giuliani E (2020) The noxious consequences of innovation: what do we know? Industry and Innovation 2(3):1-23. https://doi.org/10.1080/13662716.2020.1726729

BMBF (Bundesministerium für Bildung und Forschung) (2010) Nationale Forschungsstrategie BioÖkonomie 2030 - Unser Weg zu einer bio-basierten Wirtschaft. https://www.bmbf.de/pub/Nationale_ Forschungsstrategie_Biooekonomie_2030.pdf. Accessed 15.05.2017.

BMBF (Bundesministerium für Bildung und Forschung) (2011) Ergebnisbericht: Evaluation des Rahmenprogramms Biotechnologie. https://www.bmbf.de/pub/evaluation_rahmenprogramm_ biotechnologie.pdf. Accessed 18.08.2020.

BMBF (Bundesministerium für Bildung und Forschung) (2017a) Förderkatalog. https://foerderportal.bund.de/ foekat/jsp/StartAction.do?actionMode=list. Accessed 05.04.2017.

BMBF (Bundesministerium für Bildung und Forschung) (2017b) Fortschritt durch Forschung und Innovation - Bericht zur Umsetzung der Hightech-Strategie. https://www.kmc-chemnitz.de/files/cto_layout/img/ Inhalt/download/2017_Fortschritt_durch_Forschung_und_Innovation.pdf. Accessed 18.08.2020.

BMBF (Bundesministerium für Bildung und Forschung) (2017c) FuE-Ausgaben der Bundesrepublik Deutschland und ihre Finanzierung - Zeitreihe: 1965 - 2015. http://www.datenportal.bmbf.de/portal/1.1. 2. Accessed 18.08.2020.

BMBF (Bundesministerium für Bildung und Forschung) (2017d) Innovation durch Biotechnologie - Zehn Jahre KMU-innovativ: Biotechnologie - BioChance. https://www.bmbf.de/pub/Innovation_durch_ Biotechnologie.pdf. Accessed 18.08.2020.

BMBF (Bundesministerium für Bildung und Forschung) (2020) Bioökonomie - Biobasierte Ressourcen und biologisches Wissen für eine nachhaltige Wirtschaft. https://www.bmbf.de/de/biooekonomie-neuekonzepte-zur-nutzung-natuerlicher-ressourcen-726.html. Accessed 18.08.2020.

BMBF (Bundesministerium für Bildung und Forschung), BMEL (Bundesministerium für Ernährung und Landwirtschaft) (2020) Nationale Bioökonomiestrategie. https:/www.bmel.de/SharedDocs/Downloads/ DE/Broschueren/nationale-biooekonomiestrategie-langfassung.pdf?_blob=publicationFile \&v=3. Accessed 18.08.2020.

BMEL (Bundesministerium für Ernährung und Landwirtschaft) (2014) Nationale Politikstrategie Bioökonomie - Nachwachsende Ressourcen und biotechnologische Verfahren als Basis für Ernährung, Industrie und Energie. https://www.bmel.de/SharedDocs/Downloads/DE/Broschueren/ Biooekonomiestrategie.pdf?_blob=publicationFile\&v=3. Accessed 18.08.2020.

BT (Deutscher Bundestag) (1990) Faktenbericht 1990 zum Bundesbericht Forschung 1988. Bonn.

Bugge MM, Hansen T, Klitkou A (2016) What Is the Bioeconomy? - A Review of the Literature. Sustainability 8(7):691-713. https://doi.org/10.3390/su8070691

Büllingen F (1997) Die Genese der Magnetbahn Transrapid - Soziale Konstruktion und Evolution einer Schnellbahn. Deutscher Universitätsverlag, Wiesbaden 
Bundesregierung (2018a) Die Hightech-Strategie 2025 - Forschung und Innovationen für die Menschen. https://www.bmbf.de/pub/Forschung_und_Innovation_fuer_die_Menschen.pdf. Accessed 18.08.2020.

Bundesregierung (2018b) Koalitionsvertrag zwischen CDU, CSU und SPD - 19. Legislaturperiode. https:// www.bundesregierung.de/Content/DE/_Anlagen/2018/03/2018-03-14-koalitionsvertrag.pdf? blob= publicationFile \&v=6. Accessed 18.08.2020.

Cantner U, Pyka A (2001) Classifying technology policy from an evolutionary perspective. Research Policy 30(5):759-775

Cooke P (2007) European asymmetries - A comparative analysis of German and UK biotechnology clusters. Science and Public Policy 34(7):454 474. https://doi.org/10.3152/030234207X251425

Cooke P (2008) Regional innovation systems - origin of the species. International Journal of Technological Learning, Innovation and Development 1(3):393-409. https://doi.org/10.1504/IJTLID.2008.019980

Daimer S, Hufnagl M, Warnke P (2012) Challenge-oriented policy-making and innovation systems theory. In: Daimer S et al (eds) Innovation system revisited. Fraunhofer Verlag, Stuttgart, pp 217-234

Damanpour F (1991) Organizational Innovation: A Meta-Analysis Of Effects Of Determinants and Moderators. Academy of Management Journal 34(3):555-590. https://doi.org/10.5465/256406

de Leon P (1999) The Stages Approach to the Policy Process: What Has It Done? Where Is It Going? In: de Leon P (ed) Theories of the policy process. Westview Press, Boulder, Colo, pp 19-34

Dietz T, Börner J, Förster JJ, von Braun J (2018) Governance of the Bioeconomy - A Global Comparative Study of National Bioeconomy Strategies. Sustainability 10(9):3190. https://doi.org/10.3390/su10093190

Dohse D (2000) Technology policy and the regions - the case of the BioRegio contest. Research Policy 29(9): 1111-1133

Dohse D, Staehler T (2008) BioRegio, BioProfile and the Rise of the German Biotech Industry. Working Paper Series: Kiel Institute for the World Economy No.1456).

EC (European Commission) (2012) Innovating for Sustainable Growth - A Bioeconomy for Europe. ec.europa.eu/research/bioeconomy/pdf/official-strategy_en.pdf. Accessed 18.08.2020.

EC (European Commission) (2013) Social innovation research in the European Union - Approaches, findings and future directions - policy review. European Union, Luxembourg.

EC (European Commission) (2018) Europe 2020 strategy. https://ec.europa.eu/info/business-economy-euro/ economic-and-fiscal-policy-coordination/eu-economic-governance-monitoring-prevention-correction/ european-semester/framework/europe-2020-strategy_en. Accessed 18.08.2020.

Edler J, Fagerberg J (2017) Innovation policy - What, why, and how. Oxford Review of Economic Policy 33(1):2-23. https://doi.org/10.1093/oxrep/grx001

Edler J, Cunningham P, Gök A, Shapira P (2016) Introduction: Making sense of innovation policy. In: Edler J et al (eds) Handbook of Innovation Policy Impact. Edward Elgar Publishing, Cheltenham, pp 1-17

Eickelpasch A, Fritsch M (2005) Contests for cooperation-A new approach in German innovation policy. Research Policy 34(8):1269-1282. https://doi.org/10.1016/j.respol.2005.02.009

EP (European Parliament) (2000) Lisbon European Council 23 and 24 March 2000 - Presidency Conclusions. http://www.europarl.europa.eu/summits/lis1_en.htm. Accessed 18.08.2020.

Ergas H (1987) Does Technology Policy Matter? In: Ergas H (ed): Technology and Global Industry. National Academy Press, Washington, D.C, pp 191-245.

EU (European Union) (2020) Societal Challenges. https://ec.europa.eu/programmes/horizon2020/en/h2020section/societal-challenges. Accessed 24.07.2020.

formas (2012) Swedish Research and Innovation Strategy for a Bio-based Economy. http://www.formas.se/ PageFiles/5074/Strategy_Biobased_Ekonomy_hela.pdf. Accessed 18.08.2020.

Freeman C (1987) Technology Policy and Economic Performance - Lessons from Japan. Pinter, London

Freeman C, Lundvall B-Å (eds) (1988) Small Countries Facing the Technological Revolution. Pinter, London

Frenken K (2017) A Complexity-Theoretic Perspective on Innovation Policy. Complexity, Governance \& Networks (2017) - Special Issue: Complexity, Innovation and Policy 2017):35-37. https://doi.org/10. 20377/cgn-41.

Friedman M (1982[1962]) Capitalism and freedom, [Reprint]. The University of Chicago Press, Chicago.

GBC (German Bioeconomy Council) (2009) Combine disciplines, improve parameters, seek out international partnerships - First recommendations for research into the bio-economy in Germany. http:// biooekonomierat.de/fileadmin/Publikationen/Englisch/BOER_recommandation01.pdf. Accessed 18.08. 2020.

GBC (German Bioeconomy Council) (2016) Weiterentwicklung der "Nationalen Forschungsstrategie Bioökonomie 2030". http://biooekonomierat.de/fileadmin/Publikationen/empfehlungen/181116 Ratsempfelungen_fu_r_die_Weiterentwicklung_der_Forschungsstrategie_final.pdf. Accessed 06.02. 2019. 
GBC (German Bioeconomy Council) (2018) Internationale Bioökonomiestrategien. http://biooekonomierat. de/biooekonomie/biooekonomie-international/. Accessed 18.08.2020.

Golembiewski B, Sick N, Bröring S (2015) The emerging research landscape on bioeconomy - What has been done so far and what is essential from a technology and innovation management perspective? Innovative Food Science \& Emerging Technologies 29:308-317. https://doi.org/10.1016/j.ifset.2015.03.006

Grimm R, Fox C, Baines S, Albertson K (2013) Social innovation, an answer to contemporary societal challenges? Locating the concept in theory and practice. Innovation: The European Journal of Social Science Research 26(4):436-455. https://doi.org/10.1080/13511610.2013.848163

Hausknost D, Schriefl E, Lauk C, Kalt G (2017) A Transition to Which Bioeconomy? - An Exploration of Diverging Techno-Political Choices. Sustainability 9(4):669. https://doi.org/10.3390/su9040669

Hermans F (2018) The potential contribution of transition theory to the analysis of bioclusters and their role in the transition to a bioeconomy. Biofuels, Bioproducts and Biorefining 12(2):265-276. https://doi.org/10. $1002 / \mathrm{bbb} .1861$

Hughes A (2012) Choosing Races and Placing Bets. In: Hughes A (ed) The UK in a Global World. Centre for Economic Policy Research, London, pp 37-70

Hüsing B, Kulicke M, Wydra S, Stahlecker T, Aichinger H, Meyer N (2017) Evaluation der „Nationalen Forschungsstrategie BioÖkonomie 2030“ - Wirksamkeit der Initiativen des BMBF - Erfolg der geförderten Vorhaben - Empfehlungen zur strategischen Weiterentwicklung.

Jacobsson S, Lauber V (2006) The politics and policy of energy system transformation - explaining the German diffusion of renewable energy technology. Energy Policy 34(3):256-276. https://doi.org/10. 1016/j.enpol.2004.08.029

Jones CO (1970) An introduction to the study of public policy. Wadsworth Publishing Company, Belmont, $\mathrm{CA}$

Karp A, Beale MH, Beaudoin F, Eastmond PJ, Neal AL, Shield IF, Townsend BJ, Dobermann A (2015) Growing innovations for the bioeconomy. Nature plants 1):15193. https://doi.org/10.1038/NPLANTS. 2015.193.

Kattel R, Mazzucato M (2018) Mission-oriented innovation policy and dynamic capabilities in the public sector. Industrial and Corporate Change 27(5):787-801. https://doi.org/10.1093/icc/dty032

Kivimaa P, Kern F (2016) Creative destruction or mere niche support? - Innovation policy mixes for sustainability transitions. Research Policy 45(1):205-217. https://doi.org/10.1016/j.respol.2015.09.008

Kuhlmann S, Rip A (2018) Next-Generation Innovation Policy and Grand Challenges. Science and Public Policy 45(4):448-454. https://doi.org/10.1093/scipol/scy011

Lasswell HD (1956) The Decision Process - Seven Categories of Functional Analysis. University of Maryland, College Park, Md

Lazonick W, Tulum Ö (2011) US biopharmaceutical finance and the sustainability of the biotech business model. Research Policy 40(9):1170-1187. https://doi.org/10.1016/j.respol.2011.05.021

Lee D-H (2016) Bio-based economies in Asia - Economic analysis of development of bio-based industry in China, India, Japan, Korea, Malaysia and Taiwan. International Journal of Hydrogen Energy 41(7):43334346. https://doi.org/10.1016/j.ijhydene.2015.10.048

Martin BR (1995) Foresight in Science and Technology. Technology Analysis \& Strategic Management 7(2): 139-168. https://doi.org/10.1080/09537329508524202

Mazzucato M (2014) The Entrepreneurial State - Debunking Public vs. Private Sector Myths, Rev. ed. Anthem Press, London.

Mazzucato M (2018) Mission-oriented research \& innovation in the European Union - A problem-solving approach to fuel innovation-led growth. Publications Office, Luxembourg

Mazzucato M, Perez C (2015) Innovation as Growth Policy. In: Mazzucato M, Perez C (eds) The Triple Challenge for Europe. Oxford University Press, Oxford, pp 229-264

Mazzucato M, Semieniuk G (2017) Public financing of innovation - new questions. Oxford Review of Economic Policy 33(1):24 48. https://doi.org/10.1093/oxrep/grw036

McCann P, Ortega-Argilés R (2013) Modern regional innovation policy. Cambridge Journal of Regions, Economy and Society 6(2):187-216. https://doi.org/10.1093/cjres/rst007

McCann P, Ortega-Argilés R (2015) Smart Specialization, Regional Growth and Applications to European Union Cohesion Policy. Regional Studies 49(8):1291-1302. https://doi.org/10.1080/00343404.2013. 799769

McCormick K, Kautto N (2013) The Bioeconomy in Europe - An Overview. Sustainability 5(6):2589-2608. https://doi.org/10.3390/su5062589

McDonagh J (2014) Rural geography III: Do we really have a choice? - The bioeconomy and future rural pathways. Progress in Human Geography 39(5):658-665. https://doi.org/10.1177/0309132514563449 
Mowery DC (2006) Lessons from the History of Federal R\&D Policy for an "Energy ARPA". Testimony at Committee on Science. U.S. House of Representatives, Washington

OECD (Organisation for Economic Co-operation and Development) (2009) The Bioeconomy to 2030 Designing a Policy Agenda. http://www.oecd-ilibrary.org/economics/the-bioeconomy-to-2030_ 9789264056886-en. Accessed 18.08.2020.

OECD (Organisation for Economic Co-operation and Development) (2018) Meeting Policy Challenges for a Sustainable Bioeconomy. OECD Publishing, Paris.

Patermann C, Aguilar A (2018) The origins of the bioeconomy in the European Union. New biotechnology 40(Pt A):20-24. https://doi.org/10.1016/j.nbt.2017.04.002

Paula L, Birrer F (2006) Including Public Perspectives in Industrial Biotechnology and the Biobased Economy. Journal of Agricultural and Environmental Ethics 19(3):253-267. https://doi.org/10.1007/ s10806-005-6170-2

Petersen A, Krisjansen I (2015) Assembling ‘the bioeconomy' - Exploiting the power of the promissory life sciences. Journal of Sociology 51(1):28-46. https://doi.org/10.1177/1440783314562314

Philp J (2018) The bioeconomy, the challenge of the century for policy makers. New biotechnology 40(Pt A): 11-19. https://doi.org/10.1016/j.nbt.2017.04.004

Pietzsch J (ed) (2017) Bioökonomie für Einsteiger. Springer Spektrum, Berlin, Heidelberg

Priefer C, Jörissen J, Frör O (2017) Pathways to Shape the Bioeconomy. Resources 1(6):No.10. https://doi. org/10.3390/resources6010010

PTJ (Projektträger Jülich | Forschungszentrum Jülich GmbH) (2020) Nationale Forschungsstrategie Bioökonomie 2030. https://www.ptj.de/projektfoerderung/biooekonomie. Accessed 18.08.2020.

Purkus A, Hagemann N, Bedtke N, Gawel E (2018) Towards a sustainable innovation system for the German wood-based bioeconomy - Implications for policy design. Journal of Cleaner Production 172:3955-3968. https://doi.org/10.1016/j.jclepro.2017.04.146

Sabatier PA, Jenkins-Smith HC (eds) (1993) Policy change and learning - An advocacy coalition approach. Westview Press, Boulder, CO.

Sabatier PA, Weible CM (eds) (2014) Theories of the Policy Process. Westview Press, New York

Schot J, Steinmueller WE (2018) Three frames for innovation policy: R\&D, systems of innovation and transformative change. Research Policy 47(9):1554-1567. https://doi.org/10.1016/j.respol.2018.08.011

Schüler J (2016) Die Biotechnologie-Industrie - Ein Einführungs. Übersichts- und Nachschlagewerk, Springer Spektrum, Berlin, Heidelberg

Sillanpää M, Ncibi C (2017) A Sustainable Bioeconomy - The Green Industrial Revolution. Springer International Publishing AG, Cham

Staehler T, Dohse D, Cooke P (2006) Evaluation der Fördermaßnahmen BioRegio und BioProfile. https:// www.e-fi.de/fileadmin/Evaluationsstudien/Evaluation_der_Foerdermassnahmen_BioRegio_und_ BioProfile.pdf. Accessed 18.08.2020.

Staffas L, Gustavsson M, McCormick K (2013) Strategies and Policies for the Bioeconomy and Bio-Based Economy - An Analysis of Official National Approaches. Sustainability 5(6):2751-2769. https://doi.org/ $10.3390 / \mathrm{su} 5062751$

The White House (2012) National Bioeconomy Blueprint. https://obamawhitehouse.archives.gov/sites/ default/files/microsites/ostp/national_bioeconomy_blueprint_april_2012.pdf. Accessed 18.08.2020.

Tödtling F, Trippl M (2018) Regional innovation policies for new path development - beyond neo-liberal and traditional systemic views. European Planning Studies 26(9):1779-1795. https://doi.org/10.1080/ 09654313.2018.1457140

Viaggi D (2016) Towards an economics of the bioeconomy: four years later. Bio-based and Applied Economics 5(2):101-112

von Hayek FA (1945) The Use of Knowledge in Society. The American Economic Review 35(4):519-530

von Hayek FA (1975) Die Anmaßung von Wissen. ORDO: Jahrbuch für die Ordnung von Wirtschaft und Gesellschaft 26):12-21.

Warmuth E (1991) Biotechnology 2000 - A new German R\&D programme. Research Evaluation 1(2):79-88. https://doi.org/10.1093/rev/1.2.79

Weber KM, Rohracher H (2012) Legitimizing research, technology and innovation policies for transformative change - Combining insights from innovation systems and multi-level perspective in a comprehensive 'failures' framework. Research Policy 41(6):1037-1047. https://doi.org/10.1016/j.respol.2011.10.015

Weible CM (2014) Introducing the Scope and Focus of Policy Process Research and Theory. In: Weible CM (ed) Theories of the Policy Process. Westview Press, New York, pp 3-21

Wesseler J, von Braun J (2017) Measuring the Bioeconomy - Economics and Policies. Annual Review of Resource Economics 9(1):275-298. https://doi.org/10.1146/annurev-resource-100516-053701 
Zilberman D, Kim E, Kirschner S, Kaplan S, Reeves J (2013) Technology and the future bioeconomy. Agricultural Economics 44(supplement):95-102. https://doi.org/10.1111/agec.12054

Zinke H, El-Chichakli B, Dieckhoff P, Wydra S, Hüsing B (2016) Bioökonomie für die Industrienation Ausgangslage für biobasierte Innovationen in Deutschland verbessern. http://biooekonomierat.de/ fileadmin/Publikationen/berichte/Hintergrundpapier_ISA_Vero_ffentlichung_2.pdf. Accessed 18.08. 2020

\section{Affiliations}

\section{Leonard Prochaska $^{1}$ - Daniel Schiller ${ }^{1}$}

Daniel Schiller

daniel.schiller@uni-greifswald.de

1 Institute of Geography and Geology, University of Greifswald, Friedrich-Ludwig-Jahn-Str. 17a, 17487 Greifswald, Germany 